\title{
Millî Kütüphanede Kayıtlı 06 Mil Yz A 803 Numaralı Şiir Mecmuası*
}

Öz

\author{
Dr. Kamil Ali Gıynaş \\ Ahi Evran Üniversitesi Fen-Edebiyat Fakültesi \\ Türk Dili ve Edebiyatı Bölümü \\ kagiynas@gmail.com
}

Muhteva bakımından muhtelif çeşitleri bulunan mecmualardan biri de şiir mecmualarıdır. Şiir mecmuaları vasıtasıyla edebiyat tarihine ait birçok bilgi edinmek mümkündür. Mecmuanın derlendiği dönemde revaçta olan, kaynaklarda kendisinden hiç bahsedilmeyen, döneminde beğenilen bir şair olmasına rağmen biyografik kaynaklara girme şansı bulamayan, kaynaklarda adı geçmesine rağmen günümüze divanı ya da herhangi bir eseri ulaşamayan şairlerin şiirlerinden yahut bir şairin mürettep divan nüshalarında bulunmayıp da mecmualarda bulunan şiirlerinden haberdar olmak bu bilgilerden bazılarıdır. Bu çalışmanın esasını Millî Kütüphanede kayıtlı Yz A 803 numarayla kayıtlı 138 varaklık şiir mecmuasının ayrıntılı olarak tanıtımı ve MESTAP'a göre tablo hâline getirilmiş şekli teşkil etmektedir. Mecmuada 134 şaire ait 530 şiir ve şairleri tespit edilemeyen 85 şiirle toplam 615 adet şiir bulunmaktadır. Gazel, kasîde, musammat (tahmîs, müseddes, müsebba', terkîb-i bend) gibi farklı nazım şekilleriyle söylenmiş şiirler bulunan mecmuada en fazla şiir Bâkî'ye aittir.

Anahtar Kelimeler: Klâsik Türk Edebiyatı, mecmua geleneği, şiir mecmuaları, MESTAP.

\section{The Poetry Collection Numbered 06 Mil Yz A 803 at the National Library}

\section{Abstract}

Poetry collections are one of the collections which have various varieties in terms of content. It is possible to obtain a lot of information about the history of literature through the poetry collections. The poems which were popular in the period when the collection was compiled but were not mentioned in the sources themselves, the poets who were liked in the period but had no chance to enter into the biographical sources and the poems which could not take place in the daily divan or any other works even though they were mentioned in sources are some of this information. The basis of this study is the detailed presentation of the poetry collection of $\mathrm{Yz}$ A 803 at the National Library and the table based on MESTAP. The collection consists of 138 varak. There are 530 poems which are the works 134 poets in total. There are a total of 615 poems whose poets can not be identified. In the poetry collection, there are gazels, kasides and musammats (tahmîs, müseddes, müsebba', terkîb-i bend). The poet whose poems are included most is Bâkî.

Keywords: Classical Turkish Literature, tradition of collection, poetry collections, MESTAP.

\footnotetext{
* Bu makale, Yrd. Doç. Dr. Semra Tunç danışmanlığında tamamlanan Millî Kütüphanedeki Yz. A 803 Numaralı Mecmuanın Transkripsiyonlu Metni başlıklı Yüksek Lisans tezinden üretilmiştir. 


\section{GİRIŞ}

Türk edebiyatının önemli kaynakları arasında yer alan mecmuaların içeriğinde birçok farklı türde ve biçimde eser bulunduğu gibi, tek bir tür ve şekle münhasır mecmualar da bulunmaktadır. Örneğin, şiir mecmuaları (mecmû'a-i eş'âr), risale mecmuaları (mecmû'atü'r-resâ'il), hadis mecmuaları (mecmû'atü'l-ehâdîs), fetva mecmuaları (mecmû'a-i fetâvâ), dua mecmuaları (mecmû'a-i ed'iye), tarih manzumelerini içeren mecmualar (mecmû'a-i tevârîh), fevâid mecmuaları (mecmû'a-i fevâ'id), hutbe mecmuaları (mecmû'atü'l-huteb), tıpla ilgili mecmualar (mecmû'a-i tıb, mecmû'a-i mücerrebât, mecmû'a-i mu'âlece), gizli ilimlerden bahseden mecmualar (mecmû'atü'l-havâss, mecmû'a-i cifr ve reml, mecmû'a-i ilm-i nücûm, mecmû'a-i tılısmât, mecmû'a-i melâhîm, mecmû'a-i vefk), letaif mecmuaları (mecmû'atü'l-letâ'if), zikir ve evrâd mecmuaları (mecmû'a-i zikr ü evrâd), hikâye mecmuaları (mecmû'a-i hikâyât), münşe'ât mecmuaları (mecmû'a-i münşe'ât), müzikle ilgili mecmualar (mecmû'a-i beste ve semâ'î, mecmû'a-i mûsikî, mecmû'a-i ilâhiyyât, mecmû'a-i sâz u söz), mektup mecmuaları (mecmû'a-i mekâtib), müsvedde mecmuaları (mecmû'a-i müsevvedât), ilâm mecmuaları (mecmû'a-i sukûk), söz, deyiş mecmuaları (mecmû'a-i makâlât), hadis ve tefsir benzeri kaynaklardan edinilen dinî bilgilerin yer aldığı mecmualar (mecmû'a-i menkûlât) bunlardan bazılarıdır.

Özellikle klâsik şiirimize ait türler ve nazım şekillerine mahsus manzumelerin toplandığı mecmualar da bulunmaktadır: Kaside mecmuaları (mecmû'atü'l-kasâ'id), na't mecmuaları (mecmû'atü'n-nu'ût), gazel mecmuaları (mecmû'a-i gazeliyât), nazire mecmuaları (mecmû'atü'n-nezâ'ir), rubai mecmuaları (mecmû'ai rubâ'iyât), terkîb-i bend mecmuaları (mecmû'a-i terkîb-i bend), tercî-i bend mecmuaları (mecmû'a-i tercî-i bend), sadece müstakil beyitler bulunan mecmualar (mecmû'a-i ebyât), birden çok şairin divanlarını barındıran mecmualar (mecmû'atü'd-devâvîn) gibi. Ayrıca bazı mecmuaların derleyicilerinin adıyla anıldığı (Münşe'ât-ı Ferîdûn, Pervâne Bey Mecmû'ası vb.), bazılarının özel adları olduğu (Câmi'u' -n-nezâ'ir vb.) görülmektedir (Glynaş 2011: 246-247). ${ }^{1}$

$\mathrm{Bu}$ yazının konusunu teşkil eden mecmua da Millî Kütüphanede 06 Mil Yz A 803 numarayla kayıtlı bir şiir mecmuasıdır. ${ }^{2}$ Çalışmada mecmua ayrıntılı bir şekilde tanıtıldıktan sonra, mecmuanın içeriği Mecmuaların Sistematik Tasnifi Projesi (MESTAP) $)^{3 \prime}$ ne göre tablo hâlinde verilmiştir.

\section{Mil Yz A 803 Numaralı Mecmuanın Tanıtımı}

Millî Kütüphanede kayıtlı bulunan 803 numaralı mecmuanın künyesinde 133 varak olduğu belirtilmesine rağmen mecmua 138 varaktır. Bu durum, mecmuaya kütüphanede sonradan numara verilirken bazı sayfaların atlanarak numara verilmemesinden kaynaklanmıştır. Mecmua mavi ve kırmızı başlıklı, sırtı kenarları kahverengi meşin, ebru kaplı kartondur. Mecmuanın yazı türü ta‘lik, kâğıdı filigranlı, satır sayısı ise muhteliftir. Şirazesi bozuktur. Son yaprak sonradan yazılmıştır. Ayrıca yazı şekline bakarak derkenarların da sonradan yazıldığını söyleyebiliriz.

\footnotetext{
${ }^{1}$ Mecmuaların tasnifiyle ilgili diğer çalışmalar için bk. Gürbüz 2012, Kılıç 2012.

2 Şiir mecmuaları hakkında yapılan çalışmalar için bk. Gıynaş 2011, Tanyıldız 2012. Ayrıca makale hazırlanırken istifade edilen diğer çalışmalar için bk. Tunç 2000, Tunç 2005, Koncu-Çakır 2012, Akgül-Çetin 2013, Atila 2013, Aykanat 2013, Bakırcı 2013, Çağlayan-Balaban 2013, Özerol 2013, Öztürk 2013, Sarıçiçek 2013, Selçuk-Bellibaş 2013, Tanyıldız 2013, Yazar 2013, Mutlu 2014, Üstüner 2014, Akpınar 2015, Gençer 2015, Karadağ 2015, Tanyıldız 2015, Tunç-Sevgi 2015, Köksal 2016, Tunç 2016, Uçar 2017.

${ }^{3}$ Mecmuaların Sistematik Tasnifi Projesi (MESTAP), Prof. Dr. M. Fatih KÖKSAL'ın öneri ve teklifiyle (Köksal 2012: 409-431) hayata geçmiş bir projedir. Proje kapsamında makaleler ve yüksek lisans tezleri hazırlanmış ve yakın zamanda da www.mestap.gen.tr üzerinden metin girişi yapılmaya başlanmıştır.
} 
Mecmuanın derleyeni Vahîdî'dir. 62b'de bir gazelin başında "Li-muharrihi" ibaresi vardır ve şiir Vahîdî'ye aittir. Tezkirelerde "Vahîdî" ismine Latîfî̀ nin "Tezkiretü'ş-şu'arâ ve Tabsıratü'n-nuzamâ" adlı tezkiresinde (Canım 2000: 560) ve Fâizî'nin "Zübdetü'l-eş'âr" adlı tezkiresinde (Fâ'izî [yz.] 1621: 110a) rastladık. Ancak bu şair 1505 tarihinde öldüğünden mecmuanın derleyicisi olan Vahîdî değildir. Ayrıca Nâil Tuman'ın "Tuhfe-i Nâilî" adlı eserinde (Tuman 2001: 1158-1159) de üç adet "Vahîdî" adlı şaire rastladık. Bunlardan birincisi yukarıda bahsettiğimiz şairdir. İkincisinin ölüm tarihi 1662'dir. Dolayısıyla bu "Vahîdî" mecmuanın derleyicisi olabilir. Üçüncü "Vahîdî"nin ise Sultan I. Ahmed devrinde öldüğü belirtilmektedir. Sultan I. Ahmed 1617 tarihinde tahtta iken öldügüüden ve mecmuada 1617 'den sonra doğan şairlerin şiirleri de olduğundan bu şairin mecmuayı derleme ihtimali zayıftır.

Mecmuanın hangi dönemde derlendiğine dair kesin bir tarih bulunamamıştır. Şairlerin yaşadıkları dönemleri, tezkireleri ve edebiyat tarihlerini inceleyerek mecmuanın hangi tarihte yazıldığına dair bir tahminde bulunmaya çalıştık. Mecmuada XIV. yüzyıl ile XVII. yüzyıl arasında yaşamış şairlerin şiirleri yer almaktadır. XVIII. yüzyılda yaşamış şairlere yer verilmemesi mecmuanın XVII. yüzyılda tertip edildiğini göstermektedir. Mecmuada imla hataları olduğu görülmektedir. Örneğin, harflerin noktalarında fazlalık veya eksiklik vardır. Bu durum en fazla $\dot{\tau}$ ve $ح$ harflerinde görülmektedir. Ayrıca başlıkların da kimi zaman yanlış verildiği görülmektedir. Örneğin, 94a'da başlıkta "Nazîre-i Münîr" ibaresi vardır; ama şiir 'Amrî'ye aittir. 50b'de başlıkta "Hâlî" ibaresi vardır; ancak şiirin mahlas beyti yoktur. Muhtemelen dördüncü beyitteki "hâlî" kelimesi mahlas sanılmıştır.

Mecmuanın tertip şekline baktığımızda belli bir sistemin gözetilmediğini görüyoruz. Şiirler vezinlerine, rediflerine veya nazım şekillerine, şairlere göre sıralanmamıştır. Ancak yer yer aynı şaire ait şiirlerin arka arkaya yazıldığı görülmektedir.

Mecmuada 134 şairin 530 şiiri yer almaktadır. Bu sayı, şairi belli olmayan şiirlerle 615 olmaktadır. Şairi belli olmayan bazı şiirlerin şairleri dîvânlar, tezkireler ve mecmualar vasıtasıyla tespit edilmiş ve bu tespitler çalışmanın sonunda yer alan MESTAP tablosunda dipnotla belirtilmiştir. Şairler ve bu şairlere ait şiirler nazım şekilleriyle birlikte aşağıdaki tabloda ayrıntılı biçimde gösterilmiştir:

Tablo 1: Mecmuadaki Şiirlerin Şair ve Nazım Şekline Göre Dağılımı

\begin{tabular}{|l|l|}
\hline Şair Adı & Şiir Adedi ve Nazım Şekli \\
\hline 'Abdî & 1 gazel \\
\hline Âgehî̀ & 1 gazel \\
\hline Âhî̀ & 1 gazel \\
\hline Ahmed & 1 gazel \\
\hline Ahmed Paşa & 4 gazel \\
\hline Ahmedî & 1 gazel \\
\hline Âlî & 4 gazel \\
\hline 'Amrî̀ & 2 gazel \\
\hline 'Ârifî̀ & 1 gazel \\
\hline 'Atâ & 1 gazel \\
\hline 'Atâyî & $\begin{array}{l}39 \text { gazel, } 2 \text { tahmîs, } 2 \text { kasîde, } 1 \text { terkîb-i } \\
\text { bend, 17 matla' }\end{array}$ \\
\hline Âzâdî̀ & 1 gazel \\
\hline
\end{tabular}

SEFAD, 2017 (38): 211-264 


\begin{tabular}{|c|c|}
\hline Âzerî & 3 gazel, 1 kasîde, 1 matla' \\
\hline ‘Azîzî & 1 gazel \\
\hline 'Azmî & 1 gazel \\
\hline Bahârî & 1 gazel \\
\hline Bâkî & 80 gazel, 1 müfred \\
\hline Behiştî & 2 gazel, 1 tahmîs \\
\hline Beyânî & 1 gazel \\
\hline Ca'fer & 3 gazel \\
\hline Celâl Çelebi & 1 matla' \\
\hline Celâlî & 1 tahmîs \\
\hline Cemâlî & 1 gazel, 1 beyit \\
\hline Cem Sultan & 1 gazel \\
\hline Cilâyî & 1 gazel \\
\hline Cinânî & 1 müseddes \\
\hline Derûnî & 2 gazel \\
\hline Dervîş Çelebi & 1 gazel \\
\hline Dürrî & 1 gazel \\
\hline Emrî & 7 gazel, 1 tahmîs, 1 matla', 1 müfred \\
\hline Fasîh & 1 gazel \\
\hline Fazlî & 1 tahmîs \\
\hline Fehmî & 3 gazel \\
\hline Fevrî & 2 gazel, 1 müsebba' \\
\hline Figânî & 2 gazel \\
\hline Firâkî & 1 gazel \\
\hline Fuzûlî & 4 gazel \\
\hline Gedâyî & 2 gazel \\
\hline Gubârî & 1 gazel \\
\hline Hâdî & 1 gazel \\
\hline Hâfız-1 Konevî & 1 gazel \\
\hline Hâfız Paşa & 1 gazel \\
\hline Hâletî ('Azmi-zâde) & 3 gazel \\
\hline Halîlî & 1 gazel \\
\hline Hamdî & 2 gazel \\
\hline Hasan Çelebi (Kınalı-zâde) & 1 gazel \\
\hline Hasbî & 1 gazel \\
\hline Hâverî & 1 gazel \\
\hline Hayâlî & 4 gazel, 2 tahmîs \\
\hline Hayretî & 6 gazel \\
\hline Hayrî & 1 matla' \\
\hline Hızrî & 1 gazel \\
\hline Hicrî & 1 gazel \\
\hline Hilâlî & 3 gazel \\
\hline Hilmî & 1 gazel \\
\hline Hafî & 1 gazel \\
\hline Husrev & 2 gazel \\
\hline
\end{tabular}




\begin{tabular}{|c|c|}
\hline Hüsâmî & 1 gazel \\
\hline 'Itrî & $1 \mathrm{klt}^{\prime} \mathrm{a}$ \\
\hline İbrâhim Paşa & 1 gazel \\
\hline ‘̇̀lmî & 2 gazel \\
\hline İshâk Çelebi & 3 gazel \\
\hline '̇ंşretî & 3 gazel \\
\hline 'İzârî & 1 gazel \\
\hline Kabûlî & 17 gazel \\
\hline Kâmî (Karamanlı) & 1 matla' \\
\hline Kelîmî & 1 gazel \\
\hline Kemâl Paşa-zâde & 9 gazel \\
\hline Kemâl-i Zerd & 2 gazel \\
\hline La'lî & 1 gazel \\
\hline Levhî & 1 gazel \\
\hline Livâyî & 1 gazel \\
\hline Mahfî & 1 gazel \\
\hline Makâlî & 5 gazel \\
\hline Mesîhî & 4 gazel \\
\hline Mihrî Hatun & 1 gazel \\
\hline Misâlî & 13 gazel \\
\hline Murâdî & 3 gazel \\
\hline Münîr & 1 gazel \\
\hline Nâdirî & 2 gazel \\
\hline Nasûhî & 1 gazel \\
\hline Nazîm & 1 gazel \\
\hline Nazmî & 15 gazel \\
\hline Necâtî & 9 gazel \\
\hline Nesîmî & 1 gazel \\
\hline Nevâlî & 4 gazel \\
\hline $\mathrm{Nev}^{\prime} \hat{i}$ & 15 gazel, 1 tahmîs, 1 matla' \\
\hline Nigârî & 1 gazel \\
\hline Nikâbî & 1 gazel \\
\hline Niyâzî & 1 gazel \\
\hline Nizâmî & 1 gazel \\
\hline Rahmî & 1 gazel, 2 tahmîs \\
\hline Remzî & 2 gazel \\
\hline Revânî & 3 gazel \\
\hline Riyâzî & 1 gazel \\
\hline Rûhî & 5 gazel, 1 matla' \\
\hline Sabâyî & 2 gazel \\
\hline Sabrî & 1 tahmîs \\
\hline Sâdık & 1 gazel \\
\hline Sấr̂́ & 4 gazel, 1 müseddes \\
\hline Sâlim & 1 gazel \\
\hline Sânî & 1 gazel \\
\hline
\end{tabular}




\begin{tabular}{|c|c|}
\hline Selîmî & 1 gazel \\
\hline Senâ'î & 1 gazel \\
\hline Sirrî & 1 gazel \\
\hline Sipâhî & 1 gazel \\
\hline Sürûrî & 2 gazel \\
\hline Şâmî & 2 gazel \\
\hline Şem'î & 7 gazel \\
\hline Şemsî & 2 gazel \\
\hline Şevkî & 1 gazel \\
\hline Şeyhî & 2 gazel \\
\hline Şeyh Kemâl & 1 gazel \\
\hline Şeyhülislâm Yahyâ & 44 gazel, 1 kasîde \\
\hline Şuhûdî & 1 gazel \\
\hline Tâli'î & 2 gazel \\
\hline Tecellî & 1 gazel \\
\hline Tîgî & 3 gazel \\
\hline ‘Ubeydî & 3 gazel \\
\hline ‘Ulvî & 1 gazel \\
\hline Usûlî & 1 gazel \\
\hline Ümîdî & 15 gazel, 1 müseddes \\
\hline Vahdetî & 3 gazel \\
\hline Vahîd & 2 gazel, 1 matla' \\
\hline Vahîdî & 2 gazel \\
\hline Vasfî̀ & 3 gazel \\
\hline Veysî & 2 gazel, 1 matla' \\
\hline Visâlî & 1 gazel \\
\hline Yahyâ Bey & 4 gazel, 1 kasîde \\
\hline Yûsuf & 1 gazel \\
\hline$Z a^{\prime} f \hat{i}$ & 1 gazel \\
\hline Zâtî & 8 gazel, 1 müfred \\
\hline Zihnî & 3 gazel \\
\hline Zuhûrî & 1 gazel \\
\hline
\end{tabular}

Mecmuada 29 şiirin başlığında "nazire" ibaresi bulunmaktadır. Ancak, başlıklarında belirtilmese de 54 numaradaki Vahdetî'nin şiiri 53 numaradaki Tîgî'nin şiirine; 111 numaradaki Ulvî'nin şiiri 110 numaradaki Bâkî'nin şiirine; 511 numaradaki Gedâyî' nin şiiri 510 numaradaki İshak Çelebi'nin şiirine nazire olarak yazılmış gibidir. 426 numaralı Nasûhî’nin şiirinin başlığı yanlışlıkla "Nazîre-i Nasûhî" şeklinde kayıtlıdır; ancak şiir nazire değil zemin şiirdir ve bu şiire "Fehmî" tarafından nazire yazılmıştır. Buna göre mecmuada 18 farklı şairin 21 zemin şiirine, 25 farklı şair tarafından yazılmış 32 nazire bulunmaktadır. Mecmuada önce zemin şiire, ardından nazirelere yer verilmiştir. Zemin şiir sahipleri ve nazire yazan şairler aşağıdaki tabloda varak numaralarıyla birlikte gösterilmiştir: 
Tablo 2: Mecmuadaki Nazirelerin Dağılımı

\begin{tabular}{|c|c|}
\hline Nazire Yazan Şairler & Tanzir Edilen Şairler \\
\hline Ca'fer $(4 b)$ & Ahmed (4a) \\
\hline Nevâlî (8a) & Murâdî (8a) \\
\hline Nevâlî (8b) & Murâdî (8b) \\
\hline Vahdetî (9b) & Tîğî (9b) \\
\hline Ulvî (20a) & Bâkî (19b) \\
\hline Zihnî (64a), Abdî (64b) & Şeyhülislâm Yahyâ (64a) \\
\hline Nazmî (91a) & Kemâl Paşa-zâde (91a) \\
\hline Nazmî (91b) & Ahmed Paşa (91b) \\
\hline 'Atâ (92a), Nazmî (92b) & Hilâlî (92a) \\
\hline ‘Azmî (93a), Hüsâmî (93a) & Yahyâ Bey (92b) \\
\hline Münîr (93b), 'Amrî (94a) & Hâverî (93b) \\
\hline Fehmî (94b) & Nasûhî (94a) \\
\hline Fevrî (95a), Fevrî (95a), Nazmî (95b) & Bâkî (94b) \\
\hline Cem Sultan (96a) & Nizâmî (95b) \\
\hline Revânî (97a), Şevkî (97a) & 'Amrî (96b) \\
\hline İshak Çelebi (98a), Hilâlî, (98a), Şem‘î (98b) & Kemâl Paşa-zâde (97b) \\
\hline Zihnî (99a), Visâlî (99a), Hâfız-ı Konevî (99b) & Şeyhî (98b) \\
\hline Sürûrî (100a) & Ca'fer (99b) \\
\hline Şem’î (100b) & Zâtî (100a) \\
\hline Gedâyî (115a) & İshak Çelebi (115a) \\
\hline Şemsî (135a) & Hâfız Paşa (135a) \\
\hline
\end{tabular}

Mecmuada yer alan nazım şekillerine bakıldığında en fazla gazel nazım şeklinin yer aldığı görülmektedir. Aşağıdaki tabloda mecmuada kullanılan nazım şekilleri ve adetleri gösterilmiştir:

Tablo 3: Mecmuadaki Şiirlerin Nazım Şekline Göre Dağılımı

\begin{tabular}{|l|l|}
\hline Nazım Şekli & Adedi \\
\hline Gazel & 475 \\
\hline Matla' & 71 \\
\hline Müfred & 29 \\
\hline Tahmîs & 12 \\
\hline Nazım & 8 \\
\hline Kasîde & 5 \\
\hline Kıt'a & 3 \\
\hline Müseddes & 3 \\
\hline Terkîb-i Bend & 2 \\
\hline Türkü & 1 \\
\hline Müsebba' & 1 \\
\hline
\end{tabular}


Aşağıdaki tabloda ise mecmuada kullanılan vezinler ve sayıları verilmiştir:

Tablo 4: Mecmuada Kullanılan Aruz Kalıplarının Dağılımı

\begin{tabular}{|c|c|}
\hline Kullanılan Vezin & Adedi \\
\hline fâ'ilâtün fâ'ilâtün fâ'ilâtün fâ'ilün & 181 \\
\hline fe'ilâtün fe'ilâtün fe'ilâtün fe'ilün & 135 \\
\hline mefâ‘̂̂lün mefâ‘̂̂lün mefâ‘̂̂lün mefâ‘̂̂lün & 96 \\
\hline mef'ûlü fâ'ilâtü mefâ'îlü fâ'ilün & 63 \\
\hline mef'ûlü mefâ‘̂̂lü mefâ‘̂̂lü fe' ûlün & 41 \\
\hline mefâ‘îlün mefâ‘̂ilün fe'ûlün & 27 \\
\hline fe'ilâtün mefấilün fe'ilün & 25 \\
\hline mefâ'ilün fe'ilâtün mefâ'ilün fe'ilün & 13 \\
\hline mef'ûlü fâ'ilâtün mef'ûlü fâ'ilâtün & 9 \\
\hline mef'ûlü mefâ‘̂̂lün mef'ûlü mefâ‘̂̂lün & 7 \\
\hline müfte'ilün mefâ'ilün müfte'ilün mefâ'ilün & 4 \\
\hline fe'ilâtün fe'ilâtün fe'ilün & 3 \\
\hline $\mathrm{fe}^{\prime}$ ûlün fe'ûlün fe'ûlün fe'ûlün & 1 \\
\hline $\mathrm{fe}^{\prime}$ ûlün fe'ûlün fe'ûlün fe'ûl & 1 \\
\hline fâ'ilâtün fâ'ilâtün fâ'ilün & 1 \\
\hline müstef'ilün müstef'ilün müstef'ilün müstef'ilün & 1 \\
\hline
\end{tabular}

\section{SONUÇ}

Çalışmada Millı̂ Kütüphane'de yer alan Yz A 803 numaralı mecmuanın tanıtımı yapılmış ardından mecmuanın içeriği Mecmuaların Sistematik Tasnifi Projesi (MESTAP)' ne göre tablo hâlinde verilmiştir.

Mecmua 138 varaktan (276 sayfa) oluşmaktadır. Toplam 134 şairden 530 şiir bulunmaktadır. Şairi belli olmayan diğer manzumelerle birlikte toplam 615 şiir mevcuttur. Bu sayıya beyitler ve dörtlükler de dâhil edilmiştir. Mecmuada en fazla kullanılan üç nazım şekli gazel, matla' ve müfreddir.

Mecmuanın genelindeki şiirlerin şairleri başlıklarında belirtilmiştir. Fakat şairi bilinmeyen (yazılmayan) ve şairi yanlış yazılmış şiirler bulunmaktadır. Şairi belli olmayan kimi şiirlerin şairleri dîvânlar, tezkireler ve mecmualar vasıtasıyla tespit edilmiştir.

Zemin şiirlere ve nazirelerine de yer verilen mecmuada 18 farklı şairin 21 zemin şiirine, 25 farklı şair tarafından yazılmış 32 nazire bulunmaktadır.

Mecmuada en fazla kullanılan üç aruz kalıbı 181 adetle fấilâtün fấilâtün fấilâtün fâ'ilün, 135 adetle fe'ilâtün fe'ilâtün fe'ilâtün fe'ilün, 96 adetle mefâ'̂̂lün mefâ'îlün mefâ'îlün mefâ‘̂̂llün'dür. En az kullanılan kalıplar ise 1'er adetle fe'ûlün fe'ûlün fe'ûlün fe'ûlün, fe' ûlün fe'ûlün fe' ûlün fe' ûl, fâ'ilâtün fấilâtün fâ'ilün, müstef'ilün müstef'ilün müstef'ilün müstef'ilün'dür. 
Tablo 5: Millî Kütüphane Yz A 803 Numaralı Şiir Mecmuasının MESTAP’a Göre Muhteva Tablosu

\begin{tabular}{|c|c|c|c|c|c|c|}
\hline \multicolumn{2}{|c|}{ Yer $\mathrm{Nu}$. } & \multicolumn{5}{|l|}{ Millî Kütüphane, Yz A 803.} \\
\hline $\begin{array}{l}\text { Vrk } \\
\text { ve } \\
\text { Syf. } \\
\text { Nu. }\end{array}$ & Mahlas & Matla' Beyti / Bendi & Mahlas / Makta`'Beyti & $\begin{array}{l}\text { Nazım } \\
\text { Şekli-Türü / } \\
\text { Birim Sayıs1 }\end{array}$ & Vezin & Açıklamalar \\
\hline $1 \mathrm{~b}$ & Fașịh & $\begin{array}{l}\text { Dime esrārımı ne yār u ne bīgāne bilür } \\
\text { O rāyı ey dil-i şeydā iki peymāne bilür }\end{array}$ & $\begin{array}{l}\text { Güft u gū itmededür gaamze-i yār ile Fașiḥ } \\
\text { Ișț1lāḥ-1 gam-1 '1şḳ dil-i ferzāne bilür }\end{array}$ & gazel/5 & ..-- /..-- /..-- /..- & Başl1k: Fașị̣ \\
\hline $2 b$ & Fużüli & $\begin{array}{l}\text { Cānumuñ cevheri ol la' l-i güher-bāra fidā } \\
\text { 'Ömrümün hạạșll ol şīive-i reftāra fidā }\end{array}$ & $\begin{array}{l}\text { Ey Fużūlī n’ola ger saklar isem cān-1 ‘aziz } \\
\text { Vaḳt ola kim ola bir şūh-1 sitemkāra fidā }\end{array}$ & gazel/7 & ..-- /..-- /...- /..- & Başlık: Fużüli \\
\hline $2 b$ & $\operatorname{Nev}^{\prime} \overline{\mathrm{i}}$ & $\begin{array}{l}\text { Baña ‘ ayn-1 ' ināyet göz ucıyla bir selāmuñdur } \\
\text { Bütün dünyāca ' izzet yarım ag̉ız bir kelāmuñdur }\end{array}$ & $\begin{array}{l}\text { Șorarsañ kim durur Nev`‘̄ diyüp keyfiyyet-i hāālin } \\
\text { Kapuñda hidmete bel bağlamış kemter gulāmuñdur }\end{array}$ & gazel/5 & .---/.---/.---/.--- & Başlık: Nev' $\overline{\mathrm{i}}$ \\
\hline $3 \mathrm{a}$ & Fużūli & $\begin{array}{l}\text { Bıraḳdı hāke hüüsnüñ āfitāb-1 ālem-ārāyı } \\
\text { Götürdi yir yüzinden mu'ciz-i la' lüñ Mesịhāyı }\end{array}$ & $\begin{array}{l}\text { [Fużülī eşk seyliyle perişāān olma șabr eyle } \\
\text { Aña hem var ola āhir dutup durur mı dünyāyı] }\end{array}$ & gazel/7 & .---/.---/.---/.--- & Başlık: Fuzülī Güft \\
\hline $3 \mathrm{a}$ & Yūsuf & $\begin{array}{l}\text { Tañrum irgürse nigāruñ vașlına irsem yine } \\
\text { Şol münevver hūb cemālin ölmedin görsem yine }\end{array}$ & {$[\ldots]^{5}$} & gazel/3 & -.--/-.---/-.---/..- & Başlık: Yūsuf Güft \\
\hline $3 \mathrm{~b}$ & Firāḳi & $\begin{array}{l}\text { Aldı göñlüm ālem içre a begüm bir șarılı } \\
\text { Ka' be hakaḳı cān virürdüm aña olsam șarılı }\end{array}$ & $\begin{array}{l}\text { Ey Firāk̄ī derdmendem zeerrece ḳılmaz nazarar } \\
\text { Şāla görem ikimüzi bir döşekde șarılı }\end{array}$ & gazel/5 & -.---/.---/.---/-.- & Başlık: Firāḳi \\
\hline $3 b$ & Zāâti & $\begin{array}{l}\text { Didüm yād it beni bir merḥabādan } \\
\text { Didi hergiz elüm degmez cefādan }\end{array}$ & $\begin{array}{l}\text { Saña el virmüş iken ZZātī furșat } \\
\text { El açup vușlatı iste Hudādan }\end{array}$ & gazel/5 & .---/.---/.-- & Başlık: Zātī \\
\hline $3 b$ & & Dırahşān oldı gördüm beş hilāl üstinde hưrşīdi & & müfred/1 & .---/.---/.---/.--- & \\
\hline
\end{tabular}

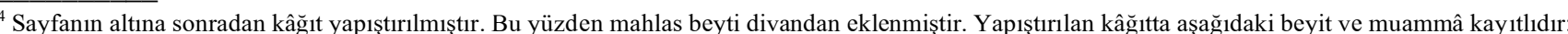

Cemālì

Namāz ehlinde yoḳdur zerrece Ḥaḳ emrine niyyet

Varup mescide gördüm dillerinde cümle ḳad kāmet

Mu'ammā

Her ki bu resmi çıḳaran ol tamām

Ol şāh ola ben aña kemter gulām

İki he he iki cỉm cìm iki lām

İki mìm ile olur ismi tamām

${ }^{5}$ Sayfanın altına sonradan kâğıt yapıștırılmıștır. Bu yüzden mahlas beyti tespit edilememiștir.

SEFAD, 2017 (38): 211-264 


\begin{tabular}{|c|c|c|c|c|c|c|}
\hline & & Meger kim pençe-i sīmine o meh-pāre yașdanmış & & & & \\
\hline $4 a$ & Bāḳi & $\begin{array}{l}\text { Bend-i ḳabā çözilmeye tā cāme çıḳmaya } \\
\text { Naḳd-i vișāl ‘āşı̣̂-1 nā-kāme çıḳmaya }\end{array}$ & $\begin{array}{l}\text { Bāḳi ḥarīir-i zülfi gibi şöyle añların } \\
\text { Sā'ir ḳumāş o serv-i gül-endāme çı̣̣maya }\end{array}$ & gazel/7 & --../-.-./.--./..-- & Başlık: Bāḳi \\
\hline $4 a$ & Aḥmed & $\begin{array}{l}\text { Șalā-yı bāde vir pīir-i ḩarābāt } \\
\text { Getür sāḳi ki fi't-te 'hîiri āfăt }\end{array}$ & $\begin{array}{l}\text { Gicenin ma' nīsi gündüzdür Ahmed } \\
\text { Șıfătıyla görinür pertev-i zāāt }\end{array}$ & gazel/5 & .---/.---/.-- & Başlık: Aḥmed \\
\hline $4 a$ & $\begin{array}{l}\text { Celāl } \\
\text { Çelebi }^{6}\end{array}$ & $\begin{array}{l}\text { Bunca feryādum işidüp dimedüñ dād idem } \\
\text { Sen ki dād itmeyesin ben kime feryād idem }\end{array}$ & & matla'/1 & ..-- /..-- /..-- /...- & Başlık: Ferd \\
\hline $4 \mathrm{~b}$ & & $\begin{array}{l}\text { Receb nāmında bir şehrī cevāna mübtelā oldum } \\
\text { O meh-māhiyyetüñ șu bānıyam ardından ayrılmam }\end{array}$ & & müfred/1 & |---/.---/.---/.--- & Başlık: Ferd \\
\hline $4 b$ & 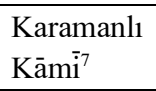 & $\begin{array}{l}\text { Güle gūş itdiremez yok yire bülbül iñler } \\
\text { Varaḳ-1 mihr ü vefāyı kim oḳur kim diñler }\end{array}$ & & matla'/1 & ..-- /..-- /..-- /..- & Başlık: Ferd \\
\hline $4 \mathrm{~b}$ & $\mathrm{Ca}^{\prime}$ fer & $\begin{array}{l}\text { Kapuñdur kıble-i erbāb-1 hạācāt } \\
\text { İşigüñ menba'-1 'izz ü sa ādāt }\end{array}$ & 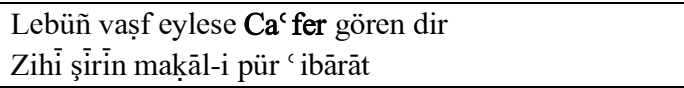 & gazel/5 & .---/.---/.-- & $\begin{array}{l}\text { Başlık: Naziire-i } \\
\mathrm{Ca}^{\prime} \text { fer }\end{array}$ \\
\hline $4 \mathrm{~b}$ & Yahyāà & $\begin{array}{l}\text { Yapdı bu 'āli makāāmı açdı cennet kapususın } \\
\text { Cāmi' ü'l-ḩayrāt olan sulțān-ı ehl-i iḳtidā }\end{array}$ & $\begin{array}{l}\text { Bende-i efgende Yahyyānuñ dilinden bir dahı } \\
\text { Beyt-i tārihe nazịire oldı bu beyt-i du'ā }\end{array}$ & gazel/10 & -.--/-.---/-.----.- & Başlık: Yaḥyā \\
\hline $5 \mathrm{a}$ & İshāạk & $\begin{array}{l}\text { Perī-șūret melek-simā imişsin } \\
\text { Güzeller içre müsteșnā imişsin }\end{array}$ & $\begin{array}{l}\text { O gül-ruhsārı ḩoş vașf itdi İsḥāk } \\
\text { Be sen hod bülbül-i gūyā imişsin }\end{array}$ & gazel/5 & .---/.---/.-- & Başlık: İsḥak \\
\hline $5 \mathrm{a}$ & & $\begin{array}{l}\text { Şişse-i hecr olsa yirüm n'ola mānend-i gül-āb } \\
\text { Ey felek bir tāze ter gülden çıḳarduñ sen beni }\end{array}$ & & müfred/1 & -.---/-.--/-.--/-.- & Başlık: Ferd \\
\hline $5 \mathrm{a}$ & & 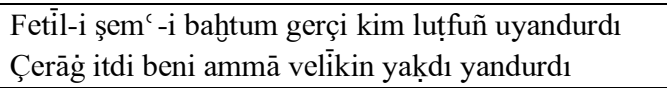 & & matla'/1 & .---/.---/.---/.--- & Başlık: Ferd \\
\hline $5 b$ & $\mathrm{Nev}^{\prime} \overline{\mathrm{i}}$ & $\begin{array}{l}\text { Meded ey göñlümi sihr ile meftūn eyleyen dilber } \\
\text { Alup 'aḳlum beni ' } 1 s ̧ k \text { ile mecnūn eyleyen dilber }\end{array}$ & 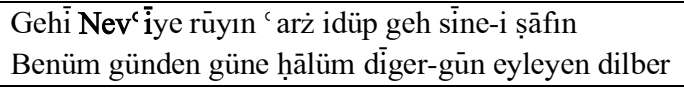 & gazel/5 & .---/.---/.---/.--- & Başlık: Nev ${ }^{c} \overline{\mathrm{i}}$ \\
\hline $5 b$ & Hayreti & $\begin{array}{l}\text { Ey dil yine yārumdan ayırdı beni devrān } \\
\text { Göz göre revānumdan ayırdı beni devrān }\end{array}$ & $\begin{array}{l}\text { Ey Hayretī devletden tāc-1 ser-i ‘izzetden } \\
\text { Yūsuf gibi āfetden ayırdı beni devrān }\end{array}$ & gazel/5 & --. /.--- /--. /.--- & Başlık: Ḥayreti \\
\hline $5 b$ & Rūḥi & $\begin{array}{l}\text { El virse șafã furșatı fevt eyleme her dem } \\
\text { Dünyā aña degmez ki cefāsın çeke ādem }\end{array}$ & & matla'/1 & (--./.--./.--./.-- & Başlık: Ferd \\
\hline $5 b$ & & $\begin{array}{l}\text { Ne reftārı ne güftārı ne ruhsārındadur hikikmet } \\
\text { Nezāketle güşād-1 bend-i şalvārındadur ḥikmet }\end{array}$ & & matla'/1 & |---/.---/.---/.--- & Başlık: Ferd \\
\hline
\end{tabular}

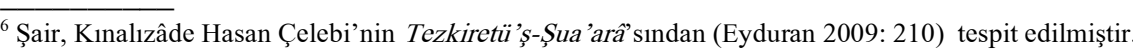

'Şair, Âş̧ı Çelebi'nin Meşâirü 'ş-Şu'arầ'sindan (Kılıç 2010: II/718) tespit edilmiştir.

${ }^{8}$ Şair, Bağdatlı Rûhî Dîvânı'ndan (Ak 2001: 190) tespit edilmiştir. Beyit, Rûhî’nin "Sַanmañ bizi kim şire-i engūr ile mestüz/Biz ehl-i harābātdanuz mest-i elestüz" beytiyle başlayan meşhur Terkîb-i Bend'inin yedinci bendinin vâsita beytidir. 


\begin{tabular}{|c|c|c|c|c|c|c|}
\hline $6 a$ & & $\begin{array}{l}\text { Dilerseñ halḳa bežl ü fażl u 'adl itmek zamānuñda } \\
\text { Şehā iḥsāna lāyıḳdur bu pür-nātüvānuñ da }\end{array}$ & $\begin{array}{l}\text { Süleymān tahtına ḳașd itdi beñzer hayl-i mūr āhir } \\
\text { Ḥaț-1 miskin ẓuhūr itmiş ' ižār-1 meh-nişānuñda }\end{array}$ & nazım/3 & 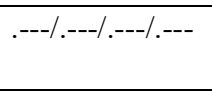 & \\
\hline $6 a$ & 'Ulvī & $\begin{array}{l}\text { Yād-1 leb-i la' lüñle bugün ḳan olayazd1 } \\
\text { Dil cür`a-ṣıfat hyāk ile yeksān olayazdı }\end{array}$ & $\begin{array}{l}\text { 'Ulvī gice āh itdi añup leyli-i zülfin } \\
\text { Mecnūn gibi 'ālemlere destān olayazdı }\end{array}$ & gazel/4 & --./.---./.--./.-- & Başlık: 'Ulvī \\
\hline $6 a$ & & $\begin{array}{l}\text { Mihr-i ruhsāārnı zikr it o mehüñ mațlac da } \\
\text { Ser-i a' dāyı nihāyet añasın maḳta da }\end{array}$ & & matla'/1 & ..-- /..-- /..-- /..- & Başlık: Müfred \\
\hline $6 a$ & $\mathrm{Nev}^{\left(\mathrm{i}^{9}\right.}$ & $\begin{array}{l}\text { Yār işi ey dil kolay ammā gam-1 ag̀yār güç } \\
\text { Vașl-1 gül āsān veli șabr-1 cefā-yı hār güç }\end{array}$ & & matla'/1 & -.--/-.---/-.--/-.-- & Başlık: Ferd \\
\hline $6 a$ & & $\begin{array}{l}\text { Maḥabbet ḳapu ḳaḳdı didi miḥnet } \\
\text { Ṣafā geldin benem bād-ı maḥabbet }\end{array}$ & & matla'/1 & .---/.---/.-- & Başlık: Ferd \\
\hline $6 a$ & & $\begin{array}{l}\text { Șalup dil fülkini ‘ ummāna āhum eyledüñ ber-bād } \\
\text { Vefāsuz rūzgār ancaḳ ḳo essüñ her çi bād-ābād }\end{array}$ & & matla'/1 & |---------------- & Başlık: Ferd \\
\hline $6 b$ & Halìi $\bar{i}$ & $\begin{array}{l}\text { Tā ki senden ayruyam işümdür ey yār ağlamaḳ } \\
\text { Bülbül-i şūírdeveş feryād idüp zār ağlamaḳ }\end{array}$ & 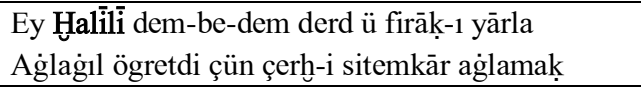 & gazel/5 & -.--/-.---/-.--/-.- & Başlık: Ḩālīili ${ }^{10}$ \\
\hline $6 b$ & Hayāli & $\begin{array}{l}\text { Neden bī-ḳayd imiş Mecnūn-1 şeydā } \\
\text { Ki ḳonmış başına biñ dürlü gavàgā }\end{array}$ & $\begin{array}{l}\text { Hูayālīnüñ dili deryāya beñzer } \\
\text { Süțur-1 şic ridür emvāc-1 deryā }\end{array}$ & gazel/5 & .---/.---/.-- & Başlık: Huayāli \\
\hline $6 b$ & & $\begin{array}{l}\text { Ni` met-i vașlını ol bug̈day ekilü dilberüñ } \\
\text { Ben degirmen kimseye ‘ālemde kendüm var iken }\end{array}$ & & müfred/1 & -.---/.---/-.--/-.- & Başlık: Ferd \\
\hline $6 b$ & & $\begin{array}{l}\text { Āsiyāb-1 felegi dāne-i encümle görüp } \\
\text { Kendümi maḥv iderem eyleyicek fikr-i dakịị }\end{array}$ & & müfred/1 & ..--/..-- /..-- /..- & Başlık: Ferd \\
\hline $6 b$ & & $\begin{array}{l}\text { Āsiyāb-1 çerh içinde eyledüm fikr-i dakīị } \\
\text { Bulmadum kendüm gibi maḥv-i vücūd eyler defîk }\end{array}$ & & müfred/1 & -.--/-.---/-.--/-.-- & Başlık: Ferd \\
\hline $7 \mathrm{a}$ & Zuhūrīi & $\begin{array}{l}\text { 'Āş1ḳam gün yüzüñüñ naḳşına māhum ezeli } \\
\text { Seni naḳḳāş-1 ezel ḳudret eliyle yazalı }\end{array}$ & $\begin{array}{l}\text { Ey Zuhūrī ḳamu yārāna yürü var haber it } \\
\text { Böyle rindāne disünler diyicek her gazeli }\end{array}$ & gazel/5 & ..-- /..-- /..-- /..- & Başlık: Zuhūrī \\
\hline $7 a$ & & $\begin{array}{l}\text { Şimdi cānā laḳabuñ çeşm-i siyāh olsa ne söz } \\
\text { Lebüñ ... }\end{array}$ & & müfred/1 & ..-- /..-- /..-- /..- & Başlık: Müfred \\
\hline $7 a$ & & $\begin{array}{l}\text { Ḩān Aḥmed itdi icrā çeşme-i Kevśer-feşān } \\
\text { Çeşme-i cūd-1 mușaffã çün hayāt-1 cāvidān }\end{array}$ & & müfred /1 & -.---/.---/-.---/.-- & $\begin{array}{l}\text { Başlık: Neş'e-i rūḥı } \\
\text { Hüseyn ile Hasan } \\
\text { '1şḳı içün }\end{array}$ \\
\hline
\end{tabular}

$\overline{9}$ Şair, Nev'î Dîvânı' ndan (Tulum-Tanyeri 1977: 255) tespit edilmiştir.

${ }^{10}$ Yazmada başlık "Firâkî̀" şeklinde kayıtlıdır; muhtemelen şair tespit edilemediğinden makta' beytindeki "firâk-1" kelimesi mahlas sanılmış "firâkî̀" şeklinde yazılmıştır. Ancak şiir Halîlı’ye aittir (Gıynaş 2014: I/840, Kavakliyazi 2015: 21).

${ }^{11}$ Yazmada mısranın devamı silik olduğundan okunamadı.

SEFAD, 2017 (38): 211-264 


\begin{tabular}{|c|c|c|c|c|c|c|}
\hline $7 \mathrm{a}$ & & $\begin{array}{l}\text { Kāle Haşmet yā ebā mā fīke lek ihrām işi(?) } \\
\text { Șāra lek be-kefï haccük kāne fi 'lük tām işi(?) }\end{array}$ & $\begin{array}{l}\text { Geldi bāb-1 Şām’a bir ḥācib didi tārīhinini } \\
\text { Sen hele ‘Abbās efendi eyledüñ ḥaccı Şām işi }\end{array}$ & nazım $/ 2$ & -.---/-.--/-.---/..- & \\
\hline $7 b$ & Dürri & $\begin{array}{l}\text { Ol şeh semend-i nāza urdı eger meger } \\
\text { Kim ehl-i ' 'ş̧ḳa geldi görindi sefer mefer }\end{array}$ & $\begin{array}{l}\text { Ey bād kạaldı Dürrīi zār intizārda } \\
\text { Kim didi saña dergeh-i şāha haber maber }\end{array}$ & gazel/7 & $\begin{array}{l}--. /-.-. / .--. /-.-- \\
\end{array}$ & Başlık: Dürri \\
\hline $7 b$ & Nazīim & $\begin{array}{l}\text { Mey-āşāmān-1 bezm-i ‘ işreti ey hāne mey-hāne } \\
\text { Huṣūșā sāḳí-i meclis șunar kestāne mestāne }\end{array}$ & $\begin{array}{l}\text { Olursa mažhar-1 feyż-i Ḩudā nuțke-1 cihān-gīiüñ } \\
\text { Nazìmā hükm ider Ṭūrān ile İrān'a mirāna }\end{array}$ & gazel/6 & .---/.---/.---/.--- & Başlık: Naẓim \\
\hline $7 b$ & & $\begin{array}{l}\text { Zülfi[ni] halkalka idüp eylemek içün üftāde } \\
\text { Beni nāra ḳodı Güdekli Çörekçi-zāde }\end{array}$ & & matla'/1 & ..-- /..-- /..-- /..- & Başlık: Ferd \\
\hline $7 b$ & & $\begin{array}{l}\text {... mış idüm meclisine üftāde }{ }^{12} \\
\text { Baña bir halḳa da virmedi Çörekçi-zāde }\end{array}$ & & matla'/1 & ..-- /..-- /..-- /..- & Başlık: Ferd \\
\hline $8 \mathrm{a}$ & Murādī & $\begin{array}{l}\text { 'Aczüm olmaz gayrıdan çün kim hayayātum sendedür } \\
\text { Cānı niçün dil ḳayursın çün penāhum sendedür }\end{array}$ & $\begin{array}{l}\text { Zāàtumı mir 'āt iderse ey Murādī añlasun } \\
\text { Ehl-i diller kim benüm zaāt u șifātum sendedür }\end{array}$ & gazel $/ 5$ & -.---/.---/-..--/..- & $\begin{array}{l}\text { Başlık: Sulțān Murād } \\
\text { Hुān }\end{array}$ \\
\hline $8 \mathrm{a}$ & Nevāli $\bar{i}$ & $\begin{array}{l}\text { Bī-ḳarār üftādeñem șabr u șebātum sendedür } \\
\text { Yoluña çoḳdan fidā oldum ḥayātum sendedür }\end{array}$ & $\begin{array}{l}\text { Habbe-i ten çāk olup oldum Nevālī uş helāk } \\
\text { Varlıġumdan yoḳ eser zāât u șifātum sendedür }\end{array}$ & gazel/5 & -.--/-.--/-.--/-.- & $\begin{array}{l}\text { Başlık: Nazīire-i } \\
\text { Nevāli Efendi }\end{array}$ \\
\hline $8 \mathrm{a}$ & & $\begin{array}{l}\text { Bagilayup resen ile ellerümi cellāda } \\
\text { Beni ḳazıḳlara urdı ol Ögütçi-zāde }\end{array}$ & & matla'/1 & ..-- /..-- /..-- /..- & Başl1k: Ferd \\
\hline $8 \mathrm{a}$ & & $\begin{array}{l}\text { Ten-i zārumı atup virdi hevā-yı bāda } \\
\text { Pāyumı haylice țoḳmaḳladı Halāc-zāde }\end{array}$ & & matla'/1 & ..-- /..-- /..-- /..- & Başlık: Ferd \\
\hline $8 \mathrm{a}$ & & $\begin{array}{l}\text { Yaḳdı tennūr-1 dili yine o serv-āzāde } \\
\text { Çı̣̆ardı dūdumı eflāke Fırıncı-zāde }\end{array}$ & & matla'/1 & ..-- /..-- /..-- /..- & Başlık: Ferd \\
\hline $8 b$ & Tīgi $\bar{i}$ & $\begin{array}{l}\text { Ķaşuñ ki dil ü cānuma gamzeñle oḳ urdı }{ }^{\circ} \text { Âlemde } \\
\text { bütün cevr [ü] cefā yayın o ḳurdı }\end{array}$ & $\begin{array}{l}\text { Tīḡì șorar ise eger ol gözleri fettān } \\
\text { Ġamzeñ göreli seyf du āsın okurdı }\end{array}$ & gazel/5 & (--./.--./.--./.-- & Başlık: Tīgi \\
\hline $8 b$ & Murādī & $\begin{array}{l}\text { Ḩaste-i '1şkam yine dermānı senden isterem } \\
\text { Her ne deñlü mücrimem guffrānı senden isterem }\end{array}$ & $\begin{array}{l}\text { Ey Murādī her ḳaçan kim eylesem anı țaleb } \\
\text { Cān u dilden țālibem bürhānı senden isterem }\end{array}$ & gazel/5 & -.--/-.---/-.--/-.- & $\begin{array}{l}\text { Başlik: Sulțān Murād } \\
\text { Hुān }\end{array}$ \\
\hline $8 b$ & Nevāli & $\begin{array}{l}\text { Cānumı ḳ̂ldum fidā cānānı senden isterem } \\
\text { Mıṣr-1 dilde Yūsuf-1 Ken'ān'1 senden isterem }\end{array}$ & $\begin{array}{l}\text { Bende-i kemter Nevālíyem yüz urdum dergehe } \\
\text { 'Āciz ü dermāndeyem dermānı senden isterem }\end{array}$ & gazel $/ 5$ & -.--/-.---/-.--/-.- & $\begin{array}{l}\text { Başlık: Nazīire-i } \\
\text { Nevāli Efendi }\end{array}$ \\
\hline $9 \mathrm{a}$ & Āzzeri & $\begin{array}{l}\text { Cām-1 '1şḳ1 nūş idüp ḳ̂l rind-i dürd-āşāmlı̣ } \\
\text { Ey göñül kām al cihāndan niçe bir nā-kāmlıḳ }\end{array}$ & $\begin{array}{l}\text { Cān ile ḳurbānuñ olsun ' 'ंd-i vașluñda senüñ } \\
\text { Āzeríye tek hemān bir būse vir bayrāmlı̣ }\end{array}$ & gazel/5 & -.--/-.---/-.--/-.- & Başlık: Āzzeri Çelebi \\
\hline $9 \mathrm{a}$ & Vahdeti $\bar{i}$ & $\begin{array}{l}\text { Kimseye ey serv gel dik gelme hāāk olsañ gerek } \\
\text { Sen de bu da'vāyı ḳo ey gül helāk olsañ gerek }\end{array}$ & $\begin{array}{l}\text { Vaḥdetī gibi yoluña cān virür bir `āşıııı } \\
\text { Bulmayup vallāhi billāhi helāk olsañ gerek }\end{array}$ & gazel/5 & -..---.---/-.--/-..- & Başlık: Vaḥdeti \\
\hline $9 \mathrm{a}$ & & $\begin{array}{l}\text { Tüy taḳınsun başına aña olan üftāde } \\
\text { Çıḳarur dīvāne 'āşı̣ları Çavuş-zāde }\end{array}$ & & matla'/1 & ..-- /..-- /..-- /..- & Başlık: Ferd \\
\hline
\end{tabular}

${ }^{12}$ Mısranın başındaki kelime okunamadı. 


\begin{tabular}{|c|c|c|c|c|c|c|}
\hline $9 b$ & Tīgi $\bar{i}$ & $\begin{array}{l}\text { Dil alur ' uşşāḳdan bir yār-i sīmīn-ber mi yok } \\
\text { 'Āşsḳ-1 dil-teng elinde yohsa sìm ü zer mi yoḳ }\end{array}$ & $\begin{array}{l}\text { Huusrev-i Hindī pesend eylerdi görse hatțuñı } \\
\text { Tỉg̈iyā şemşir-i țab' uñda senüñ cevher mi yok }\end{array}$ & gazel/7 & 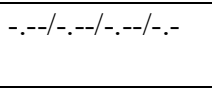 & Başlık: Tīgi $\bar{i}$ \\
\hline $9 \mathrm{~b}$ & Vaḥdetī & $\begin{array}{l}\text { Cümle 'ālem yāra mā' il bilmezin dilber mi yok } \\
\text { Yohsa ol meh-pāreye beñzer peri-peyker mi yok }\end{array}$ & $\begin{array}{l}\text { Káldı hāāi Vaḥdetī darü’ş-şifā ' uşşāḳdan } \\
\text { Bir peri-șüret güzel dīvāne-meşreb er mi yoḳ }\end{array}$ & gazel/6 & -.---/.---/-.--/-.- & Başlık: Vaḥdetī \\
\hline $9 b$ & & $\begin{array}{l}\text { Hayli demdür olalı ben o şehe üftāde } \\
\text { Yazmadı defter-i ‘ uşşāḳına Kātib-zāde }\end{array}$ & & matla'/1 & ..-- /..-- /..-- /..- & Başlık: Ferd \\
\hline $9 b$ & & $\begin{array}{l}\text { Mīve-i vașlına fehm itdi beni üftāde } \\
\text { Yazdı ser șafha-i gülnāra Yemişci-zāde }\end{array}$ & & matla'/1 & ..-- /..-- /...- /..- & Başlık: Ferd \\
\hline $9 b$ & Hayri & $\begin{array}{l}\text { Daḩ1 ḳundaḳda iken olmış idüm dil-dāde } \\
\text { Beni şaşırdı țabancayla Tüfenkçi-zāde }\end{array}$ & & matla'/1 & ..-- /..-- /...- /..- & Başlık: Hayrí \\
\hline $10 \mathrm{a}$ & 'Ulví & $\begin{array}{l}\text { Gerçi kim `āleme çok dilber-i mümtāz gelür } \\
\text { Ḥaḳ budur kim saña beñzer güzelüm az gelür }\end{array}$ & $\begin{array}{l}\text { Gerçi yüz biñ bulınur yoluña cānlar virici } \\
\text { Șanma ' Ulvī gibi bir 'āşı̣-1 ser-bāz gelür }\end{array}$ & gazel/4 & ..-- /..-- /..-- /..- & Başlık: 'Ulvī Güft \\
\hline $10 \mathrm{a}$ & & $\begin{array}{l}\text { Eksük itme cevrüñi cānā kerem ḳ̂l dā'imā } \\
\text { Gerçi gelmezse ḥabībüm zerrece senden vefā }\end{array}$ & & matla'/1 & -.---/.---/-.---/..- & Başlık: Müfred \\
\hline $10 \mathrm{a}$ & & $\begin{array}{l}\text { Her dem güzelüm gamzeñ ider cāna cefāyı } \\
\text { Göñlüm getürür başuma her laḥẓa belāyı }\end{array}$ & $\begin{array}{l}\text { Meyden k̦ızarup ' arż-1 cemāl eyledi dildār } \\
\text { Gösterdi şafaḳdan șanasın şems-i liḳāyı }\end{array}$ & nazım/2 & --./.--./.--./.-- & \\
\hline $10 \mathrm{a}$ & & $\begin{array}{l}\text { Yār kim ruhlarına zeyn ide kāküller ile } \\
\text { Naḳli güldür ki bulur zinneti sünbüller ile }\end{array}$ & $\begin{array}{l}\text { İdelüm çeng ü çegāān ile göñül șoḥbetini } \\
\text { Șalalum `āleme āvāzeyi bülbüller ile }\end{array}$ & nazım/3 & ..-- /..-- /..-- /..- & \\
\hline $10 \mathrm{a}$ & & $\begin{array}{l}\text { 'Aceb mi Ṭaşc1-zāde olsa dilberler içre müstešnā } \\
\text { Hudā kādirdür eyler seng ü hhārādan güher peydā }\end{array}$ & & matla'/1 & .---/.---/.---/.--- & Başlık: Ferd \\
\hline $10 \mathrm{a}$ & & $\begin{array}{l}\text { Cāmi ' i hüüsnüñe ' uşşāḳ1 idüp āmāde } \\
\text { Arturur ḳāmeti maḥelde Müezzżin-zāde }\end{array}$ & & matla'/1 & ..-- /..-- /..-- /..- & Başlık: Ferd \\
\hline $10 \mathrm{a}$ & & $\begin{array}{l}\text { Bir lebi şīine șordum bu gice tenhāda } \\
\text { Kanda gitdi ' acabā diyü Mü’ezzzin-zāde }\end{array}$ & & matla'/1 & ..-- /..-- /..-- /..- & Başlık: Ferd \\
\hline $10 \mathrm{~b}$ & 'Ulvī & 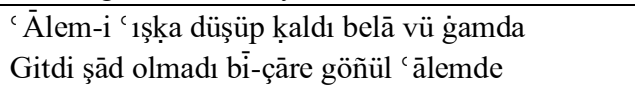 & $\begin{array}{l}\text { ‘Ömr-i Nūḥ’a n’ola reşk eylemesek ey ‘Ulvi } \\
\text { Gāh olur bir niçe biñ yll yaşaruz bir demde }\end{array}$ & gazel/5 & ..-- /..-- /...- /...- & Başl1k: 'Ulvī \\
\hline $10 \mathrm{~b}$ & Yaḥyā & $\begin{array}{l}\text { Hūn-1 eşkinden olupdur bülbülüñ her āb sürh } \\
\text { Bāğgda olsa ' aceb mi gonçe-i sír-āb sürḩ }\end{array}$ & $\begin{array}{l}\text { Zāhiri Yahyā iden ma'mūr bāṭ̂n hạālidür } \\
\text { Şişseyi gösterdügi budur şarāb-1 nāb sürḩ }\end{array}$ & gazel/5 & -.--/-.--/-.---/-.- & Başlık: Yahyā Efendi \\
\hline $10 \mathrm{~b}$ & & $\begin{array}{l}\text { Dīde pür-hūn oldı döndi reng-i cām-1 bādeye } \\
\text { Bir 'ilāc itsün șabā var söyle Keḥhāal-zādeye }\end{array}$ & & matla'/1 & -.--/-.---/-.--/-.- & Başlık: Ferd \\
\hline $10 \mathrm{~b}$ & & $\begin{array}{l}\text { Fā'ike-1 leng dimiş dilber yine tenhāda } \\
\text { Șag ayaḳ kabı degülsin hele Havvāf-zāde }\end{array}$ & & matla'/1 & ..-- /..-- /..-- /..- & Başlık: Ferd \\
\hline $10 \mathrm{~b}$ & & Ḩaṣm-1 ag̉yār ile da'vāmuzı faṣl itmek içün & & müfred/1 & ..-- /..-- /..-- /...- & Başlık: Ferd \\
\hline
\end{tabular}




\begin{tabular}{|c|c|c|c|c|c|c|}
\hline & & Beni ị̧żār-1 ḥużūr eyledi Çavuş-zāde & & & & \\
\hline $11 \mathrm{a}$ & Yahyā & $\begin{array}{l}\text { Ruh-1 dildārı rengīn vașf idersin ey dil-i şeydā } \\
\text { 'Acebdür sözlerüñden reng almazsa gül-i ra' nā }\end{array}$ & $\begin{array}{l}\text { Hevā-y1 ' 1şk u nār-1 şevk u āb-1 çeşmüñ olmasa } \\
\text { Kim ādem dir senüñ gibi ayaḳ țopraġına Yaḥyā }\end{array}$ & gazel/5 & .---/.---/.---/.--- & Başlık: Yahyyā Efendi \\
\hline $11 \mathrm{a}$ & Yahyāā & $\begin{array}{l}\text { Seḥer şehen-şeh-i çārüm serïr-i nüh-kişver } \\
\text { Diyār-1 Şām'1 alup itdi niçe fetḥ ü z̧afer }\end{array}$ & $\begin{array}{l}\text { 26. 'Arūs-1 medhüñi Yahyā müzeyyen eylemege } \\
\text { Getürdi rişte-i nażm ile niçe lü' lü-i ter } \\
\text { 30. Şeb-i siyāh gibi tỉre-bah̆t olup a' dā } \\
\text { Cihāna pertev-i devletle ol żiyā-güster }\end{array}$ & $\begin{array}{l}\text { kaside- } \\
\text { medhiyye/3 } \\
0\end{array}$ & (..-...---..-./..- & $\begin{array}{l}\text { Başlık: Kașide-i } \\
\text { Yaḥyā Efendi }\end{array}$ \\
\hline $11 \mathrm{a}$ & & $\begin{array}{l}\text { Āsiyāb-1 elem ü hecre idüp üftāde } \\
\text { Pek daḳiḳ işler işi ‘āşsḳa Uncu-zāde }\end{array}$ & & matla'/1 & ..-- /..-- /..-- /..- & Başlık: Ferd \\
\hline $11 \mathrm{a}$ & & $\begin{array}{l}\text { Ḥasretiyle reh-i miḥnetde helāk oldı tenüm } \\
\text { Mevtüme hāżı̀r ola gibi İmām-zāde benüm }\end{array}$ & & matla'/1 & ..-- /..-- /..-- /..- & Başlık: Ferd \\
\hline $11 \mathrm{a}$ & & $\begin{array}{l}\text { Eyleyüp mahkeme-i vușlatına āmāde } \\
\text { 'Işk ile eyler müdāfi' beni Ḥıżr-zāde }\end{array}$ & & matla'/1 & ..-- /..-- /..-- /..- & Başlık: Ferd \\
\hline $11 \mathrm{~b}$ & & $\begin{array}{l}\text { Heāṣıl1 '1şḳuña kendüm olalı üftāde } \\
\text { Hırmeni șabrumı șavurdı Șamancı-zāde }\end{array}$ & & matla'/1 & ..-- /..-- /..-- /..- & Başlık: Ferd \\
\hline $11 \mathrm{~b}$ & & $\begin{array}{l}\text { Varak-1 mihri o meh tọgradı virdi bāda } \\
\text { Oydı miḳrāṣ-1 ġamıla beni Fahrí-zāde }\end{array}$ & & matla'/1 & ..-- /..-- /..-- /..- & Başlık: Ferd \\
\hline $11 \mathrm{~b}$ & & $\begin{array}{l}\text { Ġayra ḳul olmamaḳ içün bu dil-i āzāde } \\
\text { Huccet-i ' 1şḳumı imżāladı Kāạîi-zāde }\end{array}$ & & matla'/1 & ..-- /..-- /..-- /..- & Başlık: Ferd \\
\hline $12 \mathrm{a}$ & & $\begin{array}{l}\text { Tamām eksülügin bildirdi māha tāke-1 min̄īda } \\
\text { Hilāl ebrūların ' arż eyleyince Muḥtesib-zāde }\end{array}$ & & matla'/1 & |--------/.---/.--- & Başlık: Ferd \\
\hline $12 \mathrm{a}$ & "Ițri & $\begin{array}{l}\text { N'idem ki eşk-i dem-ālūde ḳ̄ūy-1 yāra aḳar } \\
\text { Hezār hạasret ile dīde ol kenāre aḳar } \\
\text { Çıḳarsa dūd u fiḡānum n'ola sipihre degin } \\
\text { Cayır cayır beni oṭlaḳ Eminni-zāde yaḳar }\end{array}$ & & $\mathrm{k} 1 \mathrm{t}^{\mathrm{c}} \mathrm{a} / 1$ & .-.-...--..-.-...- & Başlık: Kiț a-i ' Ițri \\
\hline $12 b$ & Yahyā & $\begin{array}{l}\text { Hem-rāh idüp ‘adūları hoş-hạāl ider yürür } \\
\text { Ḩāk-i reh-i mahabbeti pā-māl ider yürür }\end{array}$ & $\begin{array}{l}\text { Hecriyle bí-karār idügin yāre 'arż idüp } \\
\text { Yaḥyā sirişk-i çeşmini irsāl ider yürür }\end{array}$ & gazel/5 & --. /-..-./.--. /-..- & Başlık: Yaḥyā \\
\hline $13 \mathrm{a}$ & Yahyā & $\begin{array}{l}\text { Dil-i bī-çārenüñ dildār mehcūr oldugìn ister } \\
\text { Nişān-1 tỉininüñ ol ḳaşı yā dūr olduġın ister }\end{array}$ & $\begin{array}{l}\text { Ruhuñ şevkiyle ölmek ārzūsın eylemiş Yahyā } \\
\text { Virüp ỉmān ile cān ḳabri pür-nūr olduğın ister }\end{array}$ & gazel/5 & .---/.---/.---/.--- & Başlık: Yaḥyā \\
\hline $13 \mathrm{a}$ & Yahyā & $\begin{array}{l}\text { Hemişe merdüm-i çeşmüm 'izaār-1 yāra baḳar } \\
\text { Gözüm o penceredür șạ̣n-1 lāle-zāra baḳar }\end{array}$ & $\begin{array}{l}\text { Ne i' tibār bu evżā'c a merd olan Yahyyā } \\
\text { Ne zillete naẓar eyler ne i' tibāra baḳar }\end{array}$ & gazel/5 & .-.-...---...-./.- & Başlık: Yahyā \\
\hline $13 b$ & Yahyā & $\begin{array}{l}\text { Hāțtir-1 pākine konmuş bād-1 āhumdan gubār } \\
\text { Hāk-i pāyine yitiş ey eşk eyle ic tižār }\end{array}$ & $\begin{array}{l}\text { İşigüñ̃e gözi yaşlu ‘āşıkuñ bĩñ var iken } \\
\text { Nev-cevānum biñ yaşa Yaḥyāyı itdüñ ihtiyār }\end{array}$ & gazel/5 & -.--/-.---/-.--/-.- & Başlık: Yahyyā Efendi \\
\hline
\end{tabular}




\begin{tabular}{|c|c|c|c|c|c|c|}
\hline $13 b$ & Şem ${ }^{\bar{i}} \bar{i}$ & $\begin{array}{l}\text { 'Ār idermiş beni öldürmege ol simm-tenüm } \\
\text { Varayın yalvarayın boynuma alup kefenüm }\end{array}$ & $\begin{array}{l}\text { Şem‘īyem gūşe-i mey-hāneyi virmem felege } \\
\text { Gülşen-i bāğ-1 cināndan baña yigdür vațanum }\end{array}$ & gazel $/ 5$ & ..-- /..-- /..-- /..- & Başlık: Şem‘ $\bar{i}$ \\
\hline $14 \mathrm{a}$ & Āzzeri & $\begin{array}{l}\text { Bir gice künc-i ġamda yaturdum şikeste-bāl } \\
\text { Mir āt-1 ḳalbi țutmış idi gerd-i infi āl }\end{array}$ & $\begin{array}{l}\text { 23. Mihr-i sipihr-i ‘ izzet olur Āzerēi-i zār } \\
\text { Bezmüñde aña olsa müyesser șaff-1 ni`āl } \\
\text { 30. Ġam anı añmasun ol unutsun cihān ġamın } \\
\text { Hergiz huceste hāạtırına gelmesün melāl }\end{array}$ & $\begin{array}{l}\text { kaside- } \\
\text { medhiyye/3 } \\
0\end{array}$ & --. /..-./.--../-.- & $\begin{array}{l}\text { Başlık: Kașide-i Āzerī } \\
\text { Çelebì Berāy-1 Bostan } \\
\text { Efendi-zāde }\end{array}$ \\
\hline $14 \mathrm{~b}$ & Bāḳ̄i & $\begin{array}{l}\text { Sākiyā cām-1 mey ne hoş gül olur } \\
\text { Eline kim alursa bülbül olur }\end{array}$ & $\begin{array}{l}\text { Bāḳ̄iye āb-1 vașluñ irmez ise } \\
\text { Āteş-i hecr ile yanar kül olur }\end{array}$ & gazel/5 & ..-- / ...- / ..- & Başlık: Bāḳī \\
\hline $14 \mathrm{~b}$ & 'İşreti & $\begin{array}{l}\text { Ey göñül kişverinüñ taḩtına sulțān küçücük } \\
\text { Gel esirge ḳulınam başuñ-içün cān küçücük }\end{array}$ & $\begin{array}{l}\text { Dilerüz ‘İşretī Haḳ’dan büyüyüp ola cevān } \\
\text { İnci dişlüce şeker sözlüce ogglan küçücük }\end{array}$ & gazel $/ 5$ & ..-- /..-- /..-- /..- & Başlik: 'İşreti \\
\hline $15 \mathrm{a}$ & Necātī & $\begin{array}{l}\text { Dil kişverine zülf-i siyāhuñ belā yeter } \\
\text { Y1ḳmaga bu vilāyeti bir ejdehā yeter }\end{array}$ & $\begin{array}{l}\text { Tek yirde gökde zerre ḳadar minnet olmasun } \\
\text { Örti döşek Necātīye bir būriyā yeter }\end{array}$ & gazel/6 & --./-.../.--.//..- & Başlık: Necātī \\
\hline $15 \mathrm{a}$ & & $\begin{array}{l}\text { Be zālim terk itdüñ beni } \\
\text { Șag̀ ol var ol şimden girü } \\
\text { Hercāyisin bildüm seni } \\
\text { Șag ol var ol şimden girü }\end{array}$ & $\begin{array}{l}\text { 'Işḳ olmaz imiş miḥnetsüz } \\
\text { Derd olmaz imiş fürḳatsüz } \\
\text { Yüri be hey haḳiḳatsüz } \\
\text { Șag ol var ol şimden girü }\end{array}$ & türkü/4 & 8'li hece & Başlık: Türkü \\
\hline $15 \mathrm{a}$ & Nesimi $\bar{i}$ & $\begin{array}{l}\text { Her seher vaḳtinde kim bülbül fig̀ānın başlar } \\
\text { Āhum artar şöyle kim aḳar gözümden yaşlar }\end{array}$ & $\begin{array}{l}\text { Şöyle terk itdi Nesīmi cānını Hak yolına } \\
\text { Kanda ḳaldı ata ana ḳavm ile ḳardaşlar }\end{array}$ & gazel/6 & -.--/-.---/-.--/-.- & Başlık: Nesimīi \\
\hline $15 b$ & Nevālī & $\begin{array}{l}\text { Cüdā ister beni devrān leb-i şirin-zebānumdan } \\
\text { Baña aciñ kim ayrılmaḳ görindi țatlu cānumdan }\end{array}$ & $\begin{array}{l}\text { Uyarımaz o yārı bir nefescik ḩ̌āb-1 nāzından } \\
\text { Nevālī uyımaz halk-1 cihān gerçi fig̀ānumdan }\end{array}$ & gazel $/ 5$ & .---/.---/.---/.--- & Başlık: Nevāli \\
\hline $15 b$ & Bāḳi & $\begin{array}{l}\text { Müşkil imiş ki dil-rübā țfl ola dil-sitān ola } \\
\text { ' Āş1ḳ-1 zār u mübtelā pīr ola nā-tüvān ola }\end{array}$ & 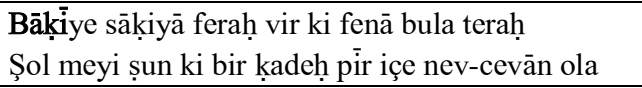 & gazel/5 &..$--/$ /.-.-/.../.-.- & Başlık: Bāḳ̄i \\
\hline $16 \mathrm{a}$ & Selimīi & $\begin{array}{l}\text { Maḥabbet şāhınuñ bir bende-i fermānıyuz cānā } \\
\text { Gedā-yı kūy-1 'ışḳuz 'ālemüñ sulțānıyuz cānā }\end{array}$ & $\begin{array}{l}\text { Selīmīiveş lebüñ vașfin idüp şīin edā ile } \\
\text { Zamānuñ himmetüñle Husrev-i devrānıyuz cānā }\end{array}$ & gazel/5 & .---/.---/.---/.--- & $\begin{array}{l}\text { Başlık: Sulțān Selīm } \\
\text { Hān }\end{array}$ \\
\hline $16 \mathrm{a}$ & Kabūlì & $\begin{array}{l}\text { Ey țıfl-1 sirişküm ḳatı ḳalg̈ırduñ a dıñ dıñ } \\
\text { Halvā-yı leb-i dilberi gördüñ yine diñ diñ }\end{array}$ & $\begin{array}{l}\text { Raḥm eyler idi yaşumuza yār Kabūlī } \\
\text { Aġyār geçüp ḳarşumuza gülmese giñ giñ }\end{array}$ & gazel/5 & ---./.--./.--./.-- & Başlık: Kabūli \\
\hline $16 \mathrm{a}$ & Kabūli & $\begin{array}{l}\text { Ġubār-1 hatț-1 lac lüñ gàayet ile hurde yazmışlar } \\
\text { Șanasın sūre-i Kevșer durur bir dürde yazmışlar }\end{array}$ & $\begin{array}{l}\text { Senüñ yoluñda ölmekden ḳaçar diyü münāfiḳlar } \\
\text { Ḳabūli ol şeh-i ḥüsne bizi öldürde yazmışlar }\end{array}$ & gazel/5 & .---/.---/.---/.--- & Başlık: Kabūli \\
\hline $16 b$ & Kabūli & $\begin{array}{l}\text { Yatur pīr-i mugàan evgār olup desti ḳabak țutmaz } \\
\text { Şu deñlü bāde-nūş olmuş kim el ditrer ayaḳ țutmaz }\end{array}$ & $\begin{array}{l}\text { Kabūli gevher-i genc-i ma`ārif bī-revāc ancaḳ } \\
\text { Dür-i naẓm-1 kelām-1 pāküñe kimse kulaḳ țutmaz }\end{array}$ & gazel $/ 5$ & .---/.---/.---/.--- & Başlık: Kabūli \\
\hline $16 \mathrm{~b}$ & Vaḥdeti $\bar{i}$ & $\begin{array}{l}\text { Cānumı ḳaşuña ḳurbān ideyin n’olsa gerek } \\
\text { Alnuma kilk-i ḳażā çekdügi resm olsa gerek }\end{array}$ & $\begin{array}{l}\text { Dem bu demdür berü gel bezm-i gama Vaḥdetiyā } \\
\text { İçelüm bāde-i '1ş̧̣̂ be diye n'olsa gerek }\end{array}$ & gazel/7 & ..-- /..-- /..-- /..- & Başlık: Vaḥdetī \\
\hline $16 \mathrm{~b}$ & Fiḡāni & Ķaşlaruñ țuggrası cānā āfitāb üstindedür & Țutalum kim ser-be-ser sulțān-1 ‘ àlemsin bu gün & gazel/5 & -.--/-.---/-.--/-.- & Başlık: Figānī \\
\hline
\end{tabular}




\begin{tabular}{|c|c|c|c|c|c|c|}
\hline & & Şekl-i bismillāha beñzer kim kitāb üstindedür & Ey Fiḡānī menzilüñ āhir türāb üstindedür & & & \\
\hline $17 \mathrm{a}$ & Kabūli & $\begin{array}{l}\text { Cism-i pākin görmek isterseñ șoyup hạmmāma ḳoy } \\
\text { Olmaz ol sīminn-beden gibi efendi pāk-șoy }\end{array}$ & $\begin{array}{l}\text { Ḥażret-i ‘ İsā da olsañ yaramazsın kimseye } \\
\text { Ey Kabūli sūzen-i zerle gerekse gözin oy }\end{array}$ & gazel/5 & -.---/.---/-.---.-.- & Başlık: Kabūli \\
\hline $17 \mathrm{a}$ & Kabūlì & $\begin{array}{l}\text { Gel naț } \text {-1 maḥabbetde şehā bir sen ü bir ben }^{\text {Şațranc oyunın oynayalum māt ola düşmen }}\end{array}$ & $\begin{array}{l}\text { Leclāe ise de lec iderüz nat' }{ }^{`}-1 \text { cihānda } \\
\text { Nā-dāna Kabūlí yeñilür șanma bizi sen }\end{array}$ & gazel/5 & $\begin{array}{l}--. / .--. / .--. / .-- \\
\end{array}$ & Başl1k: Ve lehu \\
\hline $17 \mathrm{~b}$ & Bāḳi & $\begin{array}{l}\text { Ālet-i hüsni mükemmel ḳad-i dil-cū da güzel } \\
\text { O siyāh gözler ile haḳ bu ki ebrū da güzel }\end{array}$ & $\begin{array}{l}\text { Söylese lafž-1 dürer-bārına söz yok Bāḳi } \\
\text { Dürc-i la' lindeki her dāne-i lü’lü de güzel }\end{array}$ & gazel/5 & ..-- /..-- /..-- /..- & $\begin{array}{l}\text { Başlık: Bāk̄i Efendi } \\
\text { Sellemellāhu }\end{array}$ \\
\hline $17 b$ & Bāḳi & $\begin{array}{l}\text { Cilā vir çeşme ey sāḳi mey-i șāf-1 muravvaḳdan } \\
\text { Kamaşdı gözlerüm cām-1 hilàl-i ‘ 'ide baḳmaḳdan }\end{array}$ & $\begin{array}{l}\text { Mukayyed olma ey Bāk̄í kemend-i keyd-i a' dāya } \\
\text { 'İnāyet Ḥażret-i Ḥaḳ'dan kerem Feyyāż-1 Muṭlaḳdan }\end{array}$ & gazel/5 & .---/.---/.---/.--- & Başlık: Bāḳi \\
\hline $18 \mathrm{a}$ & Bāḳi & $\begin{array}{l}\text { Āyine-i cemāl-i hạkịiḳat-nümā yüzüñ } \\
\text { Āb-1 zülāl-i çeşme-i șidḳ u șafā sözüñ }\end{array}$ & $\begin{array}{l}\text { Kimi ayaġuñ öpmege sarkar kimi elüñ } \\
\text { Bākīye besdür ey gül-i handān güler yüzüñ }\end{array}$ & gazel/5 & --. /-.-./.--./.-.- & Başlık: Bāḳi \\
\hline $18 \mathrm{a}$ & Maḥfï & $\begin{array}{l}\text { Öpsem seni doyınca doyınca seni öpsem } \\
\text { Öpsem dimeseñ epsem epsem dimeseñ öpsem }\end{array}$ & $\begin{array}{l}\text { Maḥfĩ ḳuluñam şāhum şāhum ḳuluñam Mạ̣fĩ } \\
\text { 'Ālem dükeli bildi bildi dükeli ‘ ālem }\end{array}$ & gazel/5 & --./.---/--./.--- & Başlık: Mahfĩ \\
\hline $18 \mathrm{~b}$ & Cilāyi $\bar{i}$ & $\begin{array}{l}\text { Nigārā vādī-i ‘'ş̧kuñda şādīden belā yigdür } \\
\text { Ki yad illerde yüz biñ yaddan bir āşinā yigdür }\end{array}$ & $\begin{array}{l}\text { Nesīm-i feyż-i luṭ̂ndan Cilāyī olma müstag̉nī } \\
\text { Sülūk ehline istignnā maḳāmından recā yigdür }\end{array}$ & gazel/5 & .---/.---/.---/.--- & Başlik: Cilāyi \\
\hline $18 \mathrm{~b}$ & Aḥmed Paşa & $\begin{array}{l}\text { Bāg̀g-1 vuşlatda ḳaçan devr itse sāḳi cām-1 mül } \\
\text { Şāhn-1 gül ḳaddüñ lebüñ gonçe yañaguuñ tāze gül }\end{array}$ & $\begin{array}{l}\text { Nażm neșr Aḥmed hemān eglenmek içündür bugün } \\
\text { Kişiden ancaḳ ḳalan bir ad imiş ölmez oġul }\end{array}$ & gazel/5 & -.--/-.---/-.--/-.- & Başlık: Aḥmed Paşa \\
\hline $19 \mathrm{a}$ & Kelimi & $\begin{array}{l}\text { Yārumuñ ḳaddi elif ben bendesinüñ lām-elif } \\
\text { Bu muḳarrer bir elif bir lām olur bir lām-elif }\end{array}$ & $\begin{array}{l}\text { Ey Kelīmī ol zül(ü)f ḳad ḳaddümi lām eyledi } \\
\text { Bu elif lām oldı ammā nice olur lām elif }\end{array}$ & gazel/5 & -.--/-.---/-.--/-.- & Başlık: Kelïmi \\
\hline $19 \mathrm{a}$ & Bāḳi & $\begin{array}{l}\text { 'Işkuñula ḳılup ḳāmetini dāl ḳaranfül } \\
\text { 'Arż itdi saña mūy-1 sefî̀d al ḳaranfül }\end{array}$ & $\begin{array}{l}\text { Geh şişe gehī köhne sifāl ile ḳılur ‘ayş } \\
\text { Bāḳiveş olup ‘işrete meyyāl ḳaranfül }\end{array}$ & gazel/5 & ---./.--./.--./.-- & Başlık: Bāḳī \\
\hline $19 b$ & 'Ulvī & $\begin{array}{l}\text { İşigüñ cānibin gözler gezer şām u sehẹer dīde } \\
\text { Irrlmaz āsitānuñdan efendi bir naẓar dīde }\end{array}$ & $\begin{array}{l}\text { Ölürsem hecr ile künc-i diyār-1 gamda ey ‘Ulvī } \\
\text { Dönüp bir kimse baḳmaz yüzüme aṣlā meger dīde }\end{array}$ & gazel/6 & & Başlık: 'Ulvī \\
\hline $19 b$ & Bākì & $\begin{array}{l}\text { Gūş senüñ haberlerüñ almaġa olsa çāremüz } \\
\text { Kāş ḳulaġumuz ḳadar eyleyelerdi pāremüz }\end{array}$ & $\begin{array}{l}\text { Dāg̀-1 siyāh-1 sīnemüz örtüle mevc-i eşk ile } \\
\text { Bir gün ola ki Bāḳiyā görmeye kimse ḳaramuz }\end{array}$ & gazel/5 &..$--/ .-.-/-. .-/ .-.-$ & Başlık: Bākī \\
\hline $20 \mathrm{a}$ & 'Ulvī & $\begin{array}{l}\text { Șubḥa dek ag̉laduḳ bu şeb țog̉madı māh-pāremüz } \\
\text { Țālic imüz açılmadı düşkün imiş sitāremüz }\end{array}$ & $\begin{array}{l}\text { Ġarḳa-i mevc-i eşk olup göz yumalum zamānede } \\
\text { Çeşm-i hasāud 'Ulviyā görmeye tā ki ḳaramuz }\end{array}$ & gazel/5 &..$--/ .-.-/-. .-/ .-.--$ & Başlık: 'Ulvī \\
\hline $20 \mathrm{a}$ & Levhị & $\begin{array}{l}\text { Ey ḩoş o dem ki lebüñ meyl-i mey-i nāb eyler } \\
\text { Dehen-i tengüñi mey gonçe-i sirāb eyler }\end{array}$ & $\begin{array}{l}\text { Levhīi-i bi-dilüñ ayruginna şāhum demidür } \\
\text { Kit }{ }^{\dagger} a-i \text { derd-i dilin ḳapuña işrāb eyler }\end{array}$ & gazel/5 & ..-- /..-- /...- /...- & Başlik: Levḥi \\
\hline $20 \mathrm{~b}$ & Emri & $\begin{array}{l}\text { Küşte-i tìg̀-1 gam-1 `1şk oldugiumçün ey melek } \\
\text { Bir zümürrüd türbe yapdı üstüme țāk-1 felek }\end{array}$ & $\begin{array}{l}\text { Kabrüm üstine kururılmış haymedür çerh Emriyā } \\
\text { Zer-țnābıdur şu' } \bar{a}^{c}-1 \text { āfitāb āhum direk }\end{array}$ & gazel/5 & -.---/.---/-.---/.-- & Başl1k: Emrī \\
\hline $20 \mathrm{~b}$ & Hayreti & $\begin{array}{l}\text { Meclis içre būse-i cānānum almak yol mıdur } \\
\text { Öldürüp ben nātüvānı cānum almaḳ yol mıdur }\end{array}$ & $\begin{array}{l}\text { Ey kilāb-1 kūy-1 dilber size n'itdi Hayretī } \\
\text { Çaġrışup her biriñüz dāmānum almaḳ yol mıdur }\end{array}$ & gazel/5 & -.--/-.--/-.---/.-- & Başlık: Ḥayretī \\
\hline
\end{tabular}




\begin{tabular}{|c|c|c|c|c|c|c|}
\hline $21 \mathrm{a}$ & 'Ațāyì & $\begin{array}{l}\text { Ag̉layup rāz-1 derūnın 'arż ider cānāne cām } \\
\text { Bāde-i ' '1şḳ ile olmışdur meger mestāne cām }\end{array}$ & $\begin{array}{l}\text { Ey ‘Atāyī muțtașil hālì degüldür bādeden } \\
\text { Mübtelādur var ise dā'im gam-ı devrāne cām }\end{array}$ & gazel/5 & -.--/-.---/-.--/-.- & Başlık: 'Ațāyi \\
\hline $21 \mathrm{a}$ & 'Ațāyì & $\begin{array}{l}\text { Ṭa`n eyler oldı hançer-i ser-tīzüñ senüñ } \\
\text { Cānā çemende hayli dili bitdi sūsenüñ }\end{array}$ & $\begin{array}{l}\text { Ġam gelse ey ‘Ațāyī harābāta düş hemān } \\
\text { Egler seni ne hālet ise eski meskenüñ }\end{array}$ & gazel/5 & --./-..-./.--. /-..- & Başlık: 'Ațāyi \\
\hline $21 b$ & 'Ațāyì & $\begin{array}{l}\text { Remedden șanmañuz sürh olduġın bu çeşm-i pür- } \\
\text { hūnuñ } \\
\text { Hुayāli gitmez oldı dīdeden ol rūy-ı gülgūnuñ }\end{array}$ & $\begin{array}{l}\text { Ne lu'b itdüñ ki çeşmin bağladuñ nāgeh ‘Ațāyīnüñ } \\
\text { Meger kār eyledi ey ḩoḳka-bāz çerh-i efsūnuñ }\end{array}$ & gazel/5 & |-------/.----/.--- & Başlık: 'Ațāyī \\
\hline $21 b$ & 'Ațāyì & $\begin{array}{l}\text { Kalurdı pençe-i gamda dil-i figende zebūn } \\
\text { Yitişmeseydi eger sāḳiyā mey-i gülgūn }\end{array}$ & $\begin{array}{l}\text { 'Ațāyī bāgìda ber-bād olan varaḳları gör } \\
\text { Cihānı șanma șaḳın menzil-i ḳarār u sükūn }\end{array}$ & gazel/5 & .-.-/..---...-./.-- & Başlık: 'Ațāyī \\
\hline $22 a$ & 'Ațāyì & $\begin{array}{l}\text { Nāṣıhā pendüñ senüñ ehl-i maḥabbet diñlemez } \\
\text { Fārìg olmaz' 1şḳ-1 dilberden nașịhat diñlemez }\end{array}$ & $\begin{array}{l}\text { Ey ‘Ațāyī ȟ̃āba varmış mesned-i nāz üzre yār } \\
\text { Ḳıșșa-i hicrānı yād itme hikāyet diñlemez }\end{array}$ & gazel/5 & -.---/.---/-.---_.-- & Başlık: 'Ațāyī \\
\hline $22 \mathrm{a}$ & 'Ațāyí & 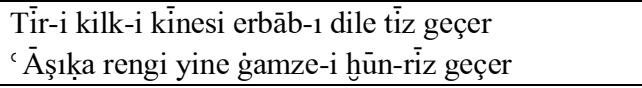 & $\begin{array}{l}\text { Reh-i '1ş̧ununda ‘Ațāyiviveş olup ser-geşte } \\
\text { Mihr-i ruhsāruña dil żerre-i nā-çiz geçer }\end{array}$ & gazel/5 & ..-- /..-- /..-- /..- & Başlık: 'Ațāyī \\
\hline $22 b$ & 'Ațāyī' & $\begin{array}{l}\text { Firkatüñle ag̉lasam aġyār-1 bed-aḩter güler } \\
\text { Ġam beni bir şekle ḳoydı hāälüme itler güler }\end{array}$ & 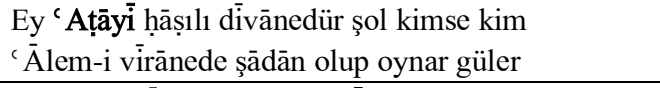 & gazel/5 & -.--/-.---/..--/-.- & Başlık: 'Ațāyī \\
\hline $22 b$ & 'Ațāyí & $\begin{array}{l}\text { Ġamzeñ hadengine olalı sīnemüz mekān } \\
\text { Kandīil-i tïrdür ten-i sūrāhumuz hemān }\end{array}$ & $\begin{array}{l}\text { Pür-dāg̀-1 sīnem üzre 'Ațāyī hadeng-i dōst } \\
\text { Beñzer o serve kim ola ețrāfi gülsitān }\end{array}$ & gazel/5 & --. /-.-. /.--. /-..- & Başlık: 'Ațāyī \\
\hline $23 a$ & 'Ațāyí & $\begin{array}{l}\text { Znevḳ alan 'ārif cem' ān bezminde nūş-1 cāmdan } \\
\text { Baş ḳaldırmaz ḥabāb-āsā mey-i gül-fāmdan }\end{array}$ & $\begin{array}{l}\text { Rūşen it kalbüüñ fürūgè-1 āfitāb-1 tāb ile } \\
\text { Ey ‘Ațāyi tire-dil olma gam-1 eyyāmdan }\end{array}$ & gazel/5 & -.--/-.---/-.--/-.-- & Başlık: 'Ațāyi \\
\hline $23 a$ & 'Ațāyì & 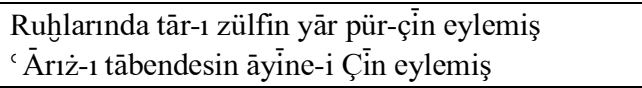 & $\begin{array}{l}\text { Ey 'Ațāyī her gedā-meşreb olur şāh-1 cihān } \\
\text { Cem șafā bezminde bir şāhāne āyin eylemiş }\end{array}$ & gazel/5 & -.---/.---/-.--/-.-- & Başlık: 'Ațāyī \\
\hline $23 b$ & 'Ațāyì & 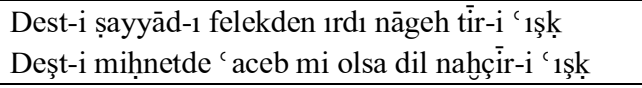 & $\begin{array}{l}\text { Ey ‘Atāyāi görinen eflākde encüm degül } \\
\text { Deldi țās-1 günbed-i gerdūnı yir yir tî̀r-i '1şk }\end{array}$ & gazel/5 & -.--/-.---/-.--/-.-- & Başlık: 'Ațāyī \\
\hline $23 b$ & 'Ațāyì & $\begin{array}{l}\text { Olmada dilde füzūn derd-i gam-1 fürḳat ise } \\
\text { Gel devā eyle țabibüm ne ḳadar zahmet ise }\end{array}$ & $\begin{array}{l}\text { Hुākden ref' ider ayaḳda ḳomaz şāh-1 cihān } \\
\text { Düş ayaġına 'Ațāyi garazuñ rif' at ise }\end{array}$ & gazel/5 & ..-- /..-- /..-- /..- & Başlık: 'Ațāyī \\
\hline $24 \mathrm{a}$ & 'Ațāyì & $\begin{array}{l}\text { Ġayr ile yār oldı dilber ben gedāyı n’eylesün } \\
\text { Yadlarla ülfet itdi āşināyı n'eylesün } \\
\text { Ehl-i dil dā 'im çeker bunca belāyı n'eylesün } \\
\text { Dil giriftār-1 belā dilber hevāyi n'eylesün } \\
\text { Dāma düşmez yirlere ḳonmaz hümāyı n'eylesün }\end{array}$ & 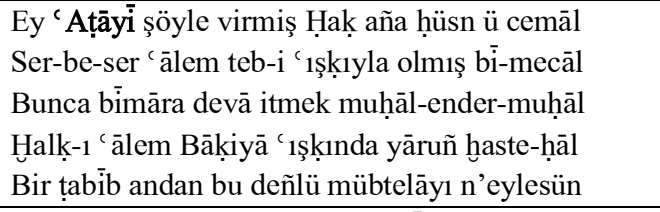 & tahmis/5 & -.--/-.---/..--/-.- & Başlık: 'Ațāyī \\
\hline $24 b$ & 'Ațāyí & $\begin{array}{l}\text { Șāf-dil bir 'āşıłunñdur ḳıl naz̧ar āyīneye } \\
\text { Ger țoḳınsa pertev-i luṭfuñ düş̧er āyineye }\end{array}$ & $\begin{array}{l}\text { Luțf idüp göñlin ele alsañ ‘Ațāyinüuñ n’ola } \\
T_{\text {Tab }} \text {-1 pāküñ beñzedür ehl-i hüner āyineye }\end{array}$ & gazel/5 & -.--/-.---/..--/-.- & Başlık: 'Ațāyī \\
\hline $25 \mathrm{a}$ & 'Ațāyì & 'Ālemi guulgulenāk itdi beşāret ḩaberi & Ey 'Ațāyī umarın cünd-i zafer rehberden & gazel/6 & ..-- /..-- /..-- /..- & Başlık: 'Ațāyī \\
\hline
\end{tabular}




\begin{tabular}{|c|c|c|c|c|c|c|}
\hline & & İrdi tā gūş-1 hilāle bu meserret huaberi & Şāh-1 dehre gele günden güne firșat ḩaberi & & & \\
\hline $25 \mathrm{a}$ & 'Ațāyì & $\begin{array}{l}\text { Görince dilleri bag̉landı hep ' uşşāk-1 nālānuñ } \\
\text { Meger dil bāġıdur başuñda ol zülf-i perişānuñ }\end{array}$ & $\begin{array}{l}\text { Ġaraż izhār ise yāra 'Ațāyī rāz-1 pinhāñ } \\
\text { Açılsun sineñ üzre yāreler çāk it giríbānuñ }\end{array}$ & gazel/5 & .---/.---/.---/.--- & Başlık: 'Ațāyì \\
\hline $25 b$ & 'Ațāyī & $\begin{array}{l}\text { Meyl idüp bir mest-i nāz u şūhh-1 bī-pervāya dil } \\
\text { Başumuz uğratdı āh u zār ile ġāvgāāya dil }\end{array}$ & $\begin{array}{l}\text { Ey ‘Ațāyí gerçi aḥbābuñ țokınmmaz göñline } \\
\text { Ṭurmaz ammā zahmm urur ḩançer gibi a' dāya dil }\end{array}$ & gazel/5 & -.--/-.---/.---/-.- & Başlık: 'Ațāyī \\
\hline $25 b$ & 'Ațāyī & $\begin{array}{l}\text { Ruh-1 rengīnüñe cānā berāber țutma mir' ātı } \\
\text { Bilürsin ‘ārıżidur hü̈nni mir'atüñ anuñ zātít }\end{array}$ & & matla'/1 & .---/.---/.---/.--- & Başlık: Ve lehu \\
\hline $25 b$ & 'Ațāyì & $\begin{array}{l}\text { Bìi-mecāl oldugiuma çekmez idüm hüüzn ü melāl } \\
\text { Olsa fí-cümle eger kūyuña varmağa mecāl }\end{array}$ & & matla'/1 & ..-- /..-- /..-- /..- & Başlık: Ve lehu \\
\hline $25 b$ & 'Ațāyì & $\begin{array}{l}\text { Tïğuñla ten-i zārda kim yāre açıldı } \\
\text { Şād oldı biraz bu dil-i bī-çāre açılddı }\end{array}$ & $\begin{array}{l}\text { Sīnemde 'Ațāyi görinüp dāğ-1 nihān }{ }^{13} \\
\text { Bildürdi gam-1 '1şḳmı dildāra açıldı }\end{array}$ & gazel/5 & ---./.--./.--./.-- & Başl1k: 'Ațāyī \\
\hline $26 \mathrm{a}$ & 'Ațāyì & $\begin{array}{l}\text { Gülüp açılsa n’ola ‘işve vü nezāket ile } \\
\text { O ġonçe göñlümüz almaḳ diler z̧arāfet ile }\end{array}$ & & matla'/1 &..$--/ . .--/ .-.-/ . .-$ & Başlık: Ve lehu \\
\hline $26 \mathrm{a}$ & 'Ațāyi & $\begin{array}{l}\text { Cem` itseler ḳ1lur seni `ālemüñ maḥal }{ }^{14} \\
\text { İksīre mālik oldılar erbāb-1 ' aḳd ü ḥal }\end{array}$ & & matla'/1 & --./-.../.--. /-.- & Başlık: Ve lehu \\
\hline $26 \mathrm{a}$ & 'Ațāyì & $\begin{array}{l}\text { Ey perī-rū seni ben hem-ser-i hūrā bilürin } \\
\text { Lebüñi ġonçe-i Firdevs-i mu allā bilürin } \\
\text { Ruh-1 rengīnüñi gül-berg-i mutarrāā bilürin } \\
\text { Ser-i kūyuñ șanemā cennet-i a' lā bilürin } \\
\text { Müntehā ḳāmetüñi Sidre vü Țūbā bilürin }\end{array}$ & 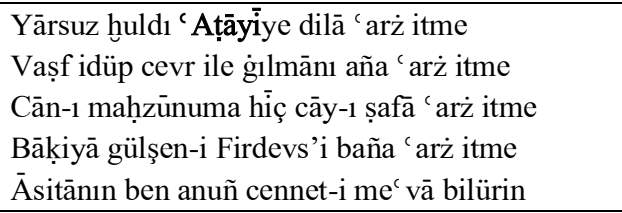 & tahmis $/ 5$ & ..-- /..-- /..-- /..- & Başlık: 'Ațāyī \\
\hline $26 b$ & 'Ațāyì & $\begin{array}{l}\text { Ġam āteşin söyündür çek āb-1 erg̉uvāni } \\
\text { Nār-1 belāya yanma çekme șaḳın duhānı }\end{array}$ & & matla'/1 &.$-- /-.--/--. / /-.--$ & Başlık: Ve lehu \\
\hline $26 b$ & 'Ațāyì & $\begin{array}{l}\text { Yansun ko nār-1 hecr ile ag̉yār-1 bed-fi' āl } \\
\text { Şeyțān ‘ azāābda yaraşur ey melek-hyıșāl }\end{array}$ & & matla'/1 &.$-- /-.-. / .--. /$-.- & Başlık: Ve lehu \\
\hline $26 b$ & 'Ațāyi & $\begin{array}{l}\text { Sīneden geçmekde tīr-i tīz-i dilber țurmayup } \\
\text { Zahm-1 pür-hūnum anuñǚn ḳanlar ağlar țurmayup }\end{array}$ & $\begin{array}{l}\text { Ey ‘Ațāyī pāy-māl eyler yürür ehl-i dili } \\
\text { Tevsen-i ser-keş gibi çerh-i sitemger țurmayup }\end{array}$ & gazel/5 & -.--/-.---/-.--/-.- & Başlık: 'Ațāyī \\
\hline $27 \mathrm{a}$ & 'Ațāyì & $\begin{array}{l}\text { Gül-sitānı 'ayş u 'işretdür meger mey-hāneler } \\
\text { Devr idüp dūlābveş anı șular peymāneler }\end{array}$ & $\begin{array}{l}\text { Ey 'Ațāyī mahrem-i bezm-i vișāl-i şem’ olup } \\
\text { Raḳ̦a girdi gice şevḳinden yine pervāneler }\end{array}$ & gazel/5 & -.---/.---/-.--/-.- & Başlık: 'Ațāyī \\
\hline $27 \mathrm{a}$ & 'Ațāyì & $\begin{array}{l}\text { Sükker-i lac l-i lebinden lezzzet almazsañ revā } \\
\text { Bí-mez̄āḳ olan ne bilsün ağzı dadın zāhidā }\end{array}$ & & matla'/1 & -.--/-.--/-.--/-.- & Başlık: Ve lehu \\
\hline $27 \mathrm{a}$ & 'Ațāyi & El uzatmazsam 'aceb mi cānib-i tesbịhe ben & & matla'/1 & -.--/-.---/-.---/-.- & Başlık: Ve lehu \\
\hline
\end{tabular}

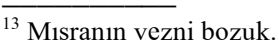

${ }^{14}$ Misranın vezni bozuk. 


\begin{tabular}{|c|c|c|c|c|c|c|}
\hline & & Zāhidā degmez elüm meclisde sāgàr țutmadan & & & & \\
\hline $27 \mathrm{a}$ & 'Ațāyi & 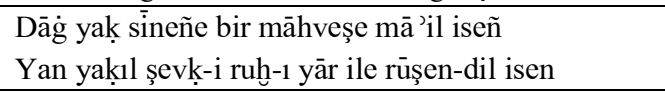 & $\begin{array}{l}\text { Gelmesün göñ̂lüñe endīse-i hatț ile gubuār } \\
\text { Pür-keder olma 'Ațāȳi gibi deryā-dil iseñ }\end{array}$ & gazel/5 &..$--/ . .--/ . .--/ . .-$ & Başlık: 'Atāyī \\
\hline $27 \mathrm{~b}$ & 'Ațāyì & $\begin{array}{l}\text { Rind-i mey-ȟrārelerüñn 'aklılın ugiurlardı müdām } \\
\text { Bezm-i meyde ele ggeldi țutulup dün gice cām }\end{array}$ & $\begin{array}{l}\text { Ey ‘Ațāyī göricek yolda seni ol ser-keș } \\
\text { Bir selāmmı dirìg itse gerekdür ne kelām }\end{array}$ & gazel/5 & ..-- /...-- /...-- /..- & Başlık: 'Atạyīi \\
\hline $27 \mathrm{~b}$ & 'Ațāyì & $\begin{array}{l}\text { Ey dīde hayāal-i lebi tek hem-demüñ olsun } \\
\text { Çek hūnn-1 ciger bezm-i belāda demüñ olsun }\end{array}$ & & matla'/1 & ---./.--./.--./.-- & Başlı: Ve lehu \\
\hline $27 \mathrm{~b}$ & 'Ațāyīi & $\begin{array}{l}\text { Çek cāmı deff } \text {-i derd-i ġam-1 dil-rübā içün } \\
\text { Cà 'iz degül mi nưş-1 mey itmek devā içün }\end{array}$ & & matla'/1 &.$-- /$ /.-../.--./.-.- & Başlı: Ve lehu \\
\hline $27 \mathrm{~b}$ & 'Ațāyì & $\begin{array}{l}\text { Vaṣl-1 yāra naḳd-i cān ile olurlar müşsterī } \\
\text { Ol metā'uñ ḳymetin a' lā bilür 'āşılkları }\end{array}$ & 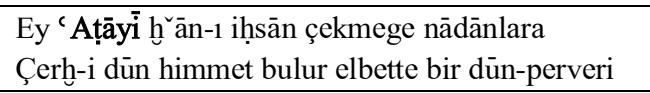 & gazel/5 & -..--/.---/..--/.-. & Başlık: 'Atāyīi \\
\hline $28 \mathrm{a}$ & 'Ațāyī & $\begin{array}{l}\text { Hatțt-1 nev-res n'ola yüz sürse ol ruhsāara bī-minnet } \\
\text { Viṣāl-i gül müyesserdür efendī hāra bì-minnet }\end{array}$ & $\begin{array}{l}\text { Edānī minnet ile ey ‘Ațāyī cāha irmekden } \\
\text { Murād el virmemek yigdür dil-i nā-çāra bī-minnet }\end{array}$ & gazel/5 & .-----------/.--- & Başlık: 'Atāȳi \\
\hline $28 \mathrm{a}$ & 'Ațāyì & $\begin{array}{l}\text { İtdi bezminde hezārān güle mey evbāş ayak } \\
\text { Haaṣ̂ll bir devre geldik kim bilinmez baş ayak }\end{array}$ & & matla'/1 & - & Başlık: 'Atāyāi \\
\hline $28 \mathrm{a}$ & 'Ațāyi & $\begin{array}{l}\text { Mihr [ü] māhın görüp aldanma gel ey bỉ-çāre } \\
\text { İki yüzlüdür inanma felek-i gaddāre }\end{array}$ & & matla'/1 &..$--/ . .--/ . .--/ . .-$ & Başlık: 'Atậyī \\
\hline $28 \mathrm{a}$ & 'Ațāyī & $\begin{array}{l}\text { Ġonçe dirse lebüñe dil n’ola zībādur bu } \\
\text { Serve beñzetsem olur ḳaddüñi a a lādur bu }\end{array}$ & $\begin{array}{l}\text { Ey ‘Ațāyāi felek elbette döner yüz çevirür } \\
\text { Șaḳın aldanma görüp mihrüñi dünyādur bu }\end{array}$ & gazel/5 &..$--/ . .--/ . .--/ . .-$ & Başlık: 'Atāyīi \\
\hline $28 \mathrm{~b}$ & 'Ațāyì & $\begin{array}{l}\text { Olmasun ġayrıya muhtāc bu kalb-i nā-şād } \\
\text { Dil-i virānumı yap yalñız eyle ābād }\end{array}$ & $\begin{array}{l}\text { N'ola ümmididi vișāal itse 'Atāāyi senden } \\
\text { Hūüblardan budur ey şūh cefâ-pişe murād }\end{array}$ & gazel/5 &..$--/ . .--/ . .--/ . .-$ & Başlı: 'Ațāyì \\
\hline $28 \mathrm{~b}$ & 'Ațāyi & $\begin{array}{l}\text { Tutsalar elde n'ola gül gibi cām-1 sahbā } \\
\text { Ġam götürmez kạtı̣ nāzük geçer erbāb-1 șafā }\end{array}$ & & matla'/1 &..$--/ . .--/ . .--/ . .-$ & Başlık: Ve lehu \\
\hline $28 \mathrm{~b}$ & 'Ațāyī & $\begin{array}{l}\text { Nāveküñ eglenmedi gitdi gelince yanuma } \\
\text { Yohsa od almaġa mı geldi dil-i sūzānuma }\end{array}$ & $\begin{array}{l}\text { Ey ‘Ațāyī gamdan öldüm dūr olaldan yārdan } \\
\text { Ḥāṣllı ‘âlem görinmez dīde-i giryānuma }\end{array}$ & gazel/5 & 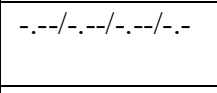 & Başlık: 'Atāyī \\
\hline $29 \mathrm{a}$ & 'Ațāyī & $\begin{array}{l}\text { Sevdüm yine bir dilber-i fettānı göñülden } \\
\text { İtsem yiridür nāle vü efğānı göñülden }\end{array}$ & 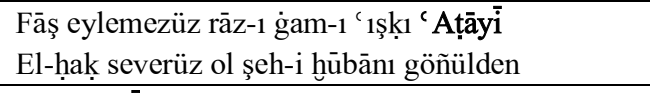 & gazel/5 &.$--- / .--. / .--. / .---$ & Başlık: 'Ațāyī \\
\hline $29 a$ & 'Ațāyī & $\begin{array}{l}\text { Nāylarla cān nālān olsa hem-dem bir nefes } \\
\text { Biz de bu bezm içre olsak şād u hurrem bir nefes }\end{array}$ & $\begin{array}{l}\text { Ey ‘Ațāyi āhumı gūş eyleyüp rahmm itse yār } \\
\text { Gam yimezdüm ol deme 'ālemde irsem bir nefes }\end{array}$ & gazel/5 & 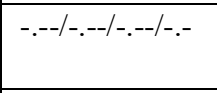 & Başlık: 'Atāyīi \\
\hline $29 \mathrm{~b}$ & 'Ațāyī & $\begin{array}{l}\text { Bagglayup șaḥn-1 çemende yine șaflar sünbül } \\
\text { Çekdi sulțān-1 şitā üstine leşker sünbül }\end{array}$ & $\begin{array}{l}\text { 32. Bāḡ-1 dilden koparup șundı ‘Ațāȳi saña } \\
\text { Bir güzel dānesi çok tāze vü hoșter sünbül } \\
\text { 37. Ser-i aḥbābuña perçem gibi gāayet yaḳş̧up }\end{array}$ & $\begin{array}{l}\text { kaside- } \\
\text { medhiyye/3 } \\
7\end{array}$ &..$--/ . .--/ . .--/ . .-$ & Başlık: 'Ațāyīi \\
\hline
\end{tabular}

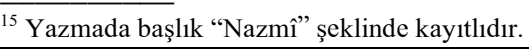

SEFAD, 2017 (38): 211-264 


\begin{tabular}{|c|c|c|c|c|c|c|}
\hline & & & Dest-i a' dāña gelince ola ejder sünbül & & & \\
\hline $31 \mathrm{a}$ & & $\begin{array}{l}\text { Eyā yegāne-i 'așr u ferīd-i devr-i zamān } \\
\text { Cihānı țutdı senüñ șit-i luțf-1 mekremetüñ }\end{array}$ & $\begin{array}{l}\text { Sipihr-i 'ilm ü fażiletde mihr-i enversin } \\
\text { 'Aceb mi sengi eger la'l liderse terbiyetüñ }\end{array}$ & nazım $/ 3$ & .-.-...--/.-.-...- & Başlık: Nazım \\
\hline $31 b$ & 'Ațāyì & $\begin{array}{l}\text { Kand-i leb-i cānāneye hem-tā dimek olmaz } \\
\text { Her buldugunñ ey țūṭi-i gūyā dimek olmaz }\end{array}$ & $\begin{array}{l}\text { Zinhār dime '1şḳuñı zühhāda 'Ațāyī } \\
\text { Bīgānelere sırruñı zírā dimek olmaz }\end{array}$ & gazel/5 & --./.--./.--./.-- & Başlık: 'Ațāyī \\
\hline $31 b$ & 'Ațāyì & $\begin{array}{l}\text { Şevk-i la' lüñü̈r dil-i pākíze gevherden garaż } \\
\text { Neş ’e-i meydür beli ' ālemde sāgardan garaż }\end{array}$ & $\begin{array}{l}\text { Ey ‘Ațāyi dil n’ola eylerse ümmìd-i vișāl } \\
\text { Ževk-i vușlațdur cihānda çünki dilberden garaż }\end{array}$ & gazel/5 & -.--/-.---/-.--/-.- & Başlık: 'Ațāyi \\
\hline $32 \mathrm{a}$ & 'Ațāyì & $\begin{array}{l}\text { Gerçi kim azdur vefāsından cefā vü nāz çok } \\
\text { Kă’ìlüz cānā hemān iḥsānuñ olsun az çoḳ }\end{array}$ & $\begin{array}{l}\text { Ey 'Ațāyì gam degül ' uşsākạa itmezse vefā } \\
\text { Cevrini tek görmesün ol dilber-i țannāz çoḳ }\end{array}$ & gazel/5 & -.--/-.---/-.--/-.- & Başlık: 'Ațāyī \\
\hline $32 \mathrm{a}$ & & $\begin{array}{l}\text { Dil-i şeydā varup bezm-i șafāda cām-1 mül çekmez } \\
\text { Lebüñ devrinde añma bāde-i nābı göñül çekmez }\end{array}$ & & matla'/1 & & Başlık: 'Ațāyī \\
\hline $32 \mathrm{a}$ & 'Ațāyì & $\begin{array}{l}\text { Her kacaçan destüñde sāgagr sākịyā yüz gösterür } \\
\text { Gūyiyā āyine-i cālem-nümā yüz gösterür }\end{array}$ & $\begin{array}{l}\text { Ey ‘Ațāyi āsitānında gören ol yārı dir } \\
\text { Āsumānda āfitāb-1 pür-żiyā yüz gösterür }\end{array}$ & gazel/5 & -.----.----.---/-.- & Başlık: 'Ațāyī \\
\hline $32 b$ & 'Ațāyī & $\begin{array}{l}\text { Kūyuña vardukça görmezsem yüzüñ cānā ne güç } \\
\text { Sana 'arż itmez gidersem hālümi ḥayfā ne güç }\end{array}$ & $\begin{array}{l}\text { Nāz ider gaam-hānede bir gice luṭf it ḳal disem } \\
\text { Ey ‘Ațāyỉ böyle ḳalursa bu istignnā ne güç }\end{array}$ & gazel/5 & -.--/-.---/-.--/-.- & Başlık: 'Ațāyī \\
\hline $32 b$ & 'Ațāyì & $\begin{array}{l}\text { Ol hatț-1 siyeh zāhir olup yār yüzinden } \\
\text { Çoḳ fitne belürdi o sitemkār yüzinden }\end{array}$ & $\begin{array}{l}\text { Zaḩm-1 sitem urmaḳda felek ḳalbe 'Ațāyī } \\
\text { Şemşīr-i ġam-1 firḳat-i dildār yüzinden }\end{array}$ & gazel/5 &.$--- / .--. / .--. / .--$ & Başlık: 'Ațāyī \\
\hline $33 \mathrm{a}$ & 'Ațāyī & $\begin{array}{l}\text { Hep güzellerden baña ol serv-ḳadd-i zíibā gelür } \\
\text { Nāz ile reftāra gelse cümleden ac lā gelür }\end{array}$ & $\begin{array}{l}\text { Ey ‘Ațāyī yig gelür baña gül gülzārdan } \\
\text { Dest-i sākịiden ki cām-1 bāde-i hamāā gelür }\end{array}$ & gazel/5 & -.--/-.---/-.--/-.- & Başlık: 'Ațāyī \\
\hline $33 \mathrm{a}$ & 'Ațāyì & $\begin{array}{l}\text { Raḳs ider meclisde bir gül yüzlü cānāndur ḳadeh } \\
\mathrm{Ba}^{\prime} \text { iś-i cem` iyyet-i erbāb-1 'irfāndur ḳadeḥ }\end{array}$ & $\begin{array}{l}\text { Ġam şebinde gevher-i 'ayş u șafāyı bulmag̉a } \\
\text { Ey 'Ațāyi elde bir şem'-i şebistāndur ḳadeh }\end{array}$ & gazel/5 & -.--/-.--/-.--/-.- & Başlık: 'Ațāyī \\
\hline $33 b$ & 'Ațāyì & 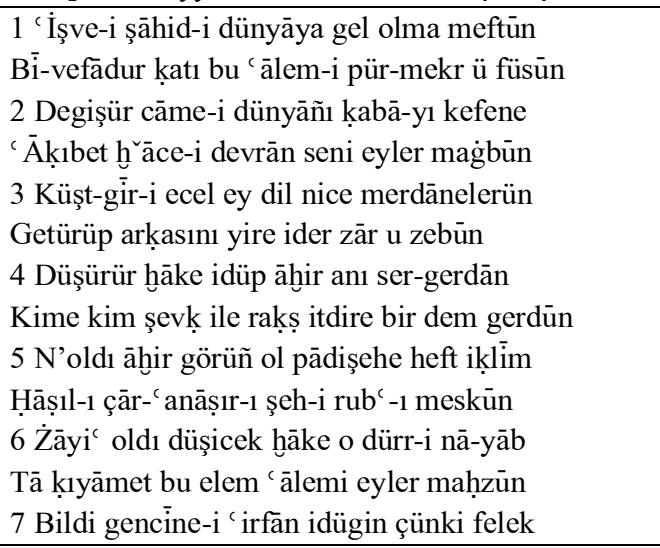 & 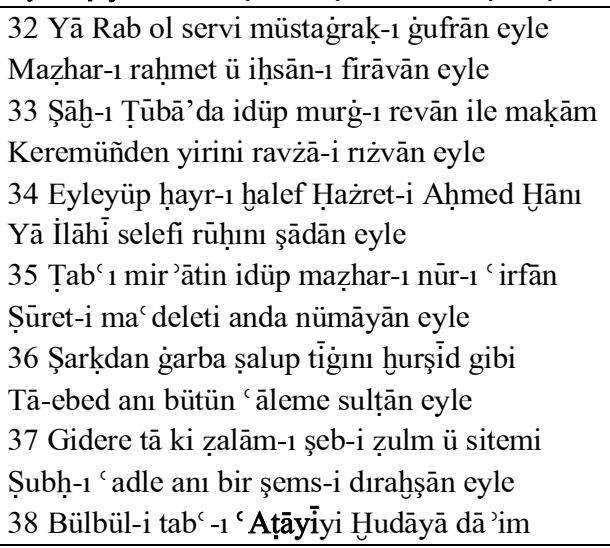 & $\begin{array}{l}\text { terkib-i } \\
\text { bend/5 }\end{array}$ & ..-- /..-- /..-- /..- & $\begin{array}{l}\text { Başlik: Merḥūm } \\
\text { Sulțān Muhammed'e } \\
\text { Merșiyye }\end{array}$ \\
\hline
\end{tabular}




\begin{tabular}{|c|c|c|c|c|c|c|}
\hline & & $\begin{array}{l}\text { Zīr-i hāa itdi yirin niteki genc-i medfūn } \\
8 \text { Cāh-1 'izzetde iken gör felek-i bed-hñāhı } \\
\text { Māh-1 Nahşseb gibi çāh itdi mekān-1 şāhı }\end{array}$ & $\begin{array}{l}\text { Gülşen-i medḥ ü șenāsında ḩoş-elhān eyle } \\
39 \text { Dilerüz hāākde yatdukça o şāh-1 merhuum } \\
\text { Şeh-i devrānı mu' ammer ide Ḥayy-1 Kayyūm }\end{array}$ & & & \\
\hline $35 b$ & 'Ațāyī & $\begin{array}{l}\text { 'Āleme fāş eyledi ‘ 1şḳuñ ġamın ey dil-rübā } \\
\text { Çıḳsa göñüümden gözümden āh ile eşküm revā }\end{array}$ & $\begin{array}{l}\text { Bulmaḳ isterseñ 'Ațāyī cevr-i gerdūndan halāṣ } \\
\text { Āsitan-1 Ḥażret-i paşaya eyle ilticā }\end{array}$ & gazel/8 & 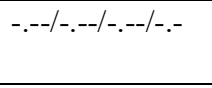 & Başlık: 'Ațāyī \\
\hline $35 b$ & 'Ațāyī & $\begin{array}{l}\text { Cānuma kār itdi çün kim '1şkk-1 bī-pāyān-1 Nūḥ } \\
\text { Başdan aşdı seyl-i eşküm nitekim țūān-1 Nūḥ }\end{array}$ & & matla'/1 & -.--/-.---/-.--/-.- & Başlık: Ve lehu \\
\hline $35 b$ & 'Ațāyī & $\begin{array}{l}\text { Görüp hatț-1 ruhuñ ağlarsa tañ mı çeşm-i gam-dīide } \\
\text { Gubār-ālüde olsa lācerem yaş aḳıdur díde }\end{array}$ & & matla'/1 & .---/.---/.---/.--- & Başlık: Ve lehu \\
\hline $35 b$ & 'Ațāyī & $\begin{array}{l}\mathrm{Na}^{\mathrm{c}} \text { ller kesmiş iken sīneme bir zahm açd1 } \\
\text { Bilmezin çāre nedür şimdi iş işden geçdi }\end{array}$ & & matla'/1 &..$--/ . .--/ . .--/ . .-$ & Başlik: Ve lehu \\
\hline $36 a$ & 'Ațāyī & $\begin{array}{l}\text { Evrāḳ-1 zanbaḳ oldı șabā ile tār-mār } \\
\text { Hükmin yürütdi mülk-i çemende şeh-i bahār }\end{array}$ & $\begin{array}{l}\text { 31. Baḥr-i suhanda haylī şināverlik eyledi } \\
\text { Kilk-i ‘Ațāyi şimdi n’ola üzülse kenār } \\
\text { 33. Bāg-1 cihānda gül gibi olup güşāāe-dil } \\
\text { Zātuñ ola serīr-i sa'ādetle pāyidār }\end{array}$ & $\begin{array}{l}\text { kaside- } \\
\text { medhiyye/3 } \\
3\end{array}$ & --. /-... /.--. /..- & Başlık: 'Ațāyī \\
\hline $37 b$ & & $\begin{array}{l}\text { Sensin ol șāḥib-i fażl u hüner ü luṭf u nevāl } \\
\text { Ki şimāl-i keremüñ ‘āleme olmış şāmil }\end{array}$ & $\begin{array}{l}\text { Niçe bir haric olam hāne-i iḥsānuñdan } \\
\text { Luṭfuña maẓhar olup vaḳtidür olsam dāḩil }\end{array}$ & nazım/2 & ..-- /..-- /..-- /..- & Başlık: Nazım \\
\hline $37 b$ & 'Ațāyī & $\begin{array}{l}\text { Der-kenār olmaz güzeller vașl-1 hūbān ber-țaraf } \\
\text { Kimsede yoḳ merḥamet 'ālemde ị̣sān ber-țaraf }\end{array}$ & $\begin{array}{l}\text { Ey 'Ațāyī şāhid-i makșūd olurdı cilveler } \\
\text { Olsa dil āyinesinde jeng-i hicrān ber-țaraf }\end{array}$ & gazel/5 & -.---/.---/.---/-.- & Başlık: 'Ațāyī \\
\hline $38 \mathrm{a}$ & Emri & $\begin{array}{l}\text { Ten-i dilberde mūveş görinen șanmañ miyānıdur } \\
\text { Der-āgūș itmiş anı ben ża' ífüñ ḳılca cānıdur }\end{array}$ & $\begin{array}{l}\text { Olup ter dīdeme vāḳı didi nükteyle bir 'ārif } \\
\text { Ne oldur Emri ne bu halḳa-i mìm-i miyānıdur }\end{array}$ & gazel/5 & '.---/.---/.---/.--- & Başl1k: Emrī \\
\hline $38 \mathrm{a}$ & Hasan & $\begin{array}{l}\text { Olaldan yār dest-i düşmen-i bed-gevher altında } \\
\text { Kalupdur ellerüm Ferhād gibi țaşlar altında }\end{array}$ & $\begin{array}{l}\text { Hasan șanma miyānıdur görinen ziri-i hançerde } \\
\text { Mis̄āl-i gencdür yatur dem-ā-dem ejder altında }\end{array}$ & gazel/5 & ----/.---/.---/.--- & $\begin{array}{l}\text { Başlık: Ḩınnāl1-zāde } \\
\text { Ḥasan Çelebi }\end{array}$ \\
\hline $38 \mathrm{~b}$ & 'Ubeydī & $\begin{array}{l}\text { Ne açılduk feżā-yı gülşene gül-pīrehenlerle } \\
\text { Ne șalınduḳ murād üzre boyı serv-i çemenlerle }\end{array}$ & $\begin{array}{l}\text { Vefã eyleñ diseydük incinürler söylemezler hịç } \\
\text { 'Ubeydī söyleşilmez hak budur gonçe-dehenlerle }\end{array}$ & gazel/5 & .---/.---/.---/.--- & Başl1k: 'Ubeydī \\
\hline $38 b$ & Kabūli & $\begin{array}{l}\text { Merhametsüz habīibi n'eylersin } \\
\text { Menfa' atsiz țabibi n'eylersin }\end{array}$ & $\begin{array}{l}\text { Yaşına baḳ Kabūlīye raḥm it } \\
\text { Ağladup bu garibi n'eylersin }\end{array}$ & gazel/5 & ..--/.-.-/..- & Başlık: Kabūli \\
\hline $39 a$ & $\operatorname{Nev}^{c} \overline{\mathrm{i}}$ & $\begin{array}{l}\text { Nāz iderseñ yaraşur mümtāz dilbersin hele } \\
\text { Öldürürseñ gam degül sulțān-1 kişversin hele }\end{array}$ & $\begin{array}{l}\text { Nev' iyā aġyār ile șohbet yaraşmaz yāre hịç } \\
\text { Saña meyl itse ne söz merd-i suhanversin hele }\end{array}$ & gazel/5 & -.--/-.---/-.--/-.- & Başlık: Nev' $\overline{\mathrm{i}}$ \\
\hline $39 a$ & Rūḥi & $\begin{array}{l}\text { Yaramı șardurayın ol büt-i ġaddāra hele } \\
\text { Görsün aġyār șarılmaḳ nice_olur yāra hele }\end{array}$ & $\begin{array}{l}\text { Ne gazazeller oḳınup yazıla evșāfuñda } \\
\text { Rūhịi-i gam-zede gelsün yine güftāra hele }\end{array}$ & gazel/6 & ..-- /..-- /..-- /..- & Başlık: Rūḥi \\
\hline $39 b$ & Kabūli & $\begin{array}{l}\text { Āfitāb-1 țal'atüñ rahşs̄ān u nūr-efşān ola } \\
\text { Kevkeb-i māhiyyetüñ şām u seherer tābān ola }\end{array}$ & $\begin{array}{l}\text { Ulu devletdür Kabūlī bende-i nā-çizi iken } \\
\text { Saña ol sulțān-1 'āali-şāndan iḥsān ola }\end{array}$ & gazel/5 & -.--/-.---/..--/-.- & Başlık: Kabūlī \\
\hline
\end{tabular}

SEFAD, 2017 (38): 211-264 


\begin{tabular}{|c|c|c|c|c|c|c|}
\hline $39 b$ & Kabūlī & $\begin{array}{l}\text { Ne şād olmaḳ murād eyle ne dilde zerrece gam țut } \\
\text { Elüñde sāgaruñ cām ittiḥād it kendüñi Cem țut }\end{array}$ & $\begin{array}{l}\text { Cihān dār-1 belādur bunda kimse şādmān olmaz } \\
\text { Kabūlì gam getürme hāạtıra göñlüñi hurrem țut }\end{array}$ & gazel/5 & ----/.---/.---/.--- & Başlık: Kabūli \\
\hline $40 \mathrm{a}$ & Kabūlì & $\begin{array}{l}\text { Egleden göñlümüzi seyr-i gül-i rūyuñdur } \\
\text { Baġlayan murg-1 dili bāg̣çç-i kūyuñdur }\end{array}$ & $\begin{array}{l}\text { Kim-durur dirseñ işigüñde Kabūli çāker } \\
\text { Dā‘ } \overline{\mathrm{i}} \text {-i devletüñ ol eski du`ā-gūyuñdur }\end{array}$ & gazel/5 & ..-- /..-- /...- /...- & Başlık: Kabūli \\
\hline $40 \mathrm{a}$ & Kabūli & $\begin{array}{l}\text { Meh-i nev keştīi deryā-yı gerdūna dümen țaḳdı } \\
\text { Şu } u^{c} \bar{a}^{-}-1 \text { āfitāb ețrāfina zerrīn resen țaḳdı }\end{array}$ & $\begin{array}{l}\text { Ķabūli mā'il-i dünyā degüldi ey göñül ammā } \\
\text { Zen-i dünyā içün birḳaç düzen düzdi țaḳan țaḳdı }\end{array}$ & gazel/5 & & Başlık: Kabūli \\
\hline $40 \mathrm{~b}$ & $\operatorname{Nev}^{c} \overline{\mathrm{i}}$ & $\begin{array}{l}\text { N'ola ḳıyāmete beñzer disem ḳad-i yārı } \\
\text { Kıyāmetüñ günidür āfitāb-1 ruhsārı }\end{array}$ & $\begin{array}{l}\text { Hevā-yı ' ışk esereri var meger ki Nev' īde } \\
\text { Açıldı perde-i rāzı bilindi esrārı }\end{array}$ & gazel/5 & .-.-...--/.-.-/..- & Başlık: Nev`啇 \\
\hline $40 \mathrm{~b}$ & Veysi $\bar{i}$ & 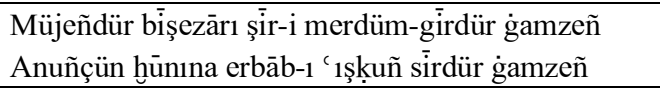 & $\begin{array}{l}\text { Dil-i Veysī țutalum țās-1 pūlād-1 sipihr olmış } \\
\text { Geçer andan da bir tîr-i ḳażā te 'șîirdür gamzeñ }\end{array}$ & gazel/5 & .---/.---/.---/.--- & Başlık: Veysī \\
\hline $41 \mathrm{a}$ & Hilāli & $\begin{array}{l}\text { Zahm-1 hadeng-i yār ile dil lālezārdur } \\
\text { Her tāze dāg tende gül-i nev-bahārdur }\end{array}$ & $\begin{array}{l}\text { Yoḳdur Hilāli gül yüzi vașfinda hem-demüñ } \\
\text { Gerçi cihānda bülbül-i şeydā hezārdur }\end{array}$ & gazel/5 & --./-..-/.--.//.-- & Başlık: Hilāli \\
\hline $41 \mathrm{a}$ & Kabūli & $\begin{array}{l}\text { O nezāket o lețāfet o țarāvet o șafā } \\
\text { O zuaāāfet o feșāhat o belāgat o edā }\end{array}$ & $\begin{array}{l}\text { Nedür ol yāra Kabūlī bu ḳadar 'izzetler } \\
\text { O teşevvuḳ o ta'alluḳ o ta'aşşuḳ o hevā }\end{array}$ & gazel/5 & ..-- /..-- /..-- /..- & Başlık: Kabūli \\
\hline $41 b$ & Mis̄āli $\bar{i}$ & $\begin{array}{l}\text { Dime bir būseme biñ cān virür çok mübtelā vardur } \\
\text { Bahāsı hüsnüñũñ șanma ki ey hüsn ü bahā vardur }\end{array}$ & $\begin{array}{l}\text { Hevā-yı kadd-i cānān ile bir yirde ḳarār itmez } \\
\text { Misāāliveş meger servüñ de başında hevā vardur }\end{array}$ & gazel/5 & .---/.---/.---/.--- & Başlık: Mis̄āli \\
\hline $41 b$ & Mis̄āli $\bar{i}$ & $\begin{array}{l}\text { Țabīb-i cānsın derd ehline sende devā vardur } \\
\text { Anuñçün işigüñ bekler yatur çoḳ mübtelā vardur }\end{array}$ & $\begin{array}{l}\text { Hemişse sāde-rūlar vașfin itmekdür anuñ şānı } \\
\text { Misālī mahlaṣı bir şā'ir-i rengīn-edā vardur }\end{array}$ & gazel/5 & .---/.---/.---/.--- & Başlık: Mis̄āli \\
\hline $41 b$ & Sālim & $\begin{array}{l}\text { Gözden ki n'idem cūy-1 sirişk aḳmag̀a gelmez } \\
\text { Āyīne-i āba o peri baḳmağa gelmez }\end{array}$ & $\begin{array}{l}\text { Hayrān olalı hüsn-i cihān-tābuña Sālim } \\
\text { Āyīne-i āba o peri baḳmag̀a gelmez }\end{array}$ & gazel/6 & ---./.--./.--./.-- & Başlık: Sālim \\
\hline $42 a$ & Emri & $\begin{array}{l}\text { Eşk-i çeşmüm gördi ol pír olası sögdi baña } \\
\text { Bu meșeldür kim erenler naḳde ḳılmışlar du }{ }^{\complement} \bar{a}\end{array}$ & $\begin{array}{l}\text { Çeşm ü ruhsārına öykünse n'ola nergisle gül } \\
\text { Anlaruñ yüzin gözin açmışdur ey Emri șabā }\end{array}$ & gazel/5 & -.--/-.---/-.--/-.- & Başlık: Emrī \\
\hline $42 a$ & Mis̄āli & $\begin{array}{l}\text { Pāy-1 semendüñ öpmedüñ itdüñ güzzār hayayf } \\
\text { Ḥayf oldı ben fütādeñe ey şeh-süvār ḥayf }\end{array}$ & $\begin{array}{l}\text { İrgürmedi gubāruñı kūy-1 nigāra āh } \\
\text { Ḥayf itdi ey Mis̄ālī saña rūzgār ḥayf }\end{array}$ & gazel/5 & --. /-... /.--. /-..- & Başlık: Mişāli \\
\hline $42 b$ & Revānī & $\begin{array}{l}\text { Şol serv gibi kāāmet-i dil-cūya ne dirsin } \\
\text { Şol güller ile kākül-i hoş-būya ne dirsin }\end{array}$ & $\begin{array}{l}\text { Zāhid dir imiş tevbelüyem cām-1 şarāba } \\
\text { Billāhi Revāni ya şu bed-hūya ne dirsin }\end{array}$ & gazel/5 & ---./.--./.--./.-- & Başlık: Revāni \\
\hline $42 b$ & Kabūli & $\begin{array}{l}\text { Şitāb idüp şitāda riḥlet idüp hāneden çıḳma } \\
\text { Żiyā-bahş ol otur āteş gibi kāşāneden çiḳma }\end{array}$ & $\begin{array}{l}\text { Kabūlī pādişāh olmaḳ dilerseñ terk-i cāh eyle } \\
\text { Ferāgat şālına gir vaż -1 dervişāāneden çıḳma }\end{array}$ & gazel/5 & "---/.---/.---/.--- & Başlık: Kabūli \\
\hline $43 a$ & Kabūlì & $\begin{array}{l}\text { Zerd iden rūyumuzı zer gibi zer yoḳlugìdur } \\
\text { Bizi ayaḳda ḳoyan elde güher yoḳluğıdur }\end{array}$ & $\begin{array}{l}\text { Nāle vü āh-1 Ḳabūlī göge çıkmaġa sebeb } \\
\text { Kūy-1 dilberde ol üftādeye yir yoḳlugìdur }\end{array}$ & gazel/5 & ..--/..-- /..-- /..- & Başlık: Kabūlī \\
\hline $43 a$ & Āzzerí & $\begin{array}{l}\text { Ey dil ruh-1 zerdüñle senüñ eşk-i terüñ yok } \\
\text { Varma der-i dildāra șaḳın sim ü zerüñ yoḳ }\end{array}$ & $\begin{array}{l}\text { Dög taşlar ile Āzeriyā gögsüñi her dem } \\
\text { İller gibi sineñde çü bir sim-berüñ yoḳ }\end{array}$ & gazel/5 & ---./.--./.--./.-- & Başl1k: Āzzerī \\
\hline $43 b$ & $\operatorname{Nev} \bar{i}$ & Kalb-i ‘āşıı gibi vīrān itdiler mey-ḩāneyi & Sen de Nev`i i muḳteżā-yı nefsi dilden dūr idüp & gazel/5 & -.---/-.--/-.--/-.-- & Başlik: Nev' $\bar{i}$ \\
\hline
\end{tabular}




\begin{tabular}{|c|c|c|c|c|c|c|}
\hline & & Bï-vefālar 'ahdine döndürdiler peymāneyi & Şāhid-i rūḥa gel iḥżār eyle hyalvet-ḩāneyi & & & \\
\hline $43 b$ & Necātì & $\begin{array}{l}\text { Bu cefādan ki kadeh aġzuñ öper döne döne } \\
\text { Nār-1 gayretde kebāb oldı ciger döne döne }\end{array}$ & $\begin{array}{l}\text { Zār u giryānlı̀ ile oldı Necātī dūlāb } \\
\text { Gülsitān-1 ser-i kūyuñı șular döne döne }\end{array}$ & gazel/5 & ..-- /..-- /..-- /..- & Başlık: Necātī \\
\hline $44 \mathrm{a}$ & $\overline{\text { Āzzeri }}$ & $\begin{array}{l}\text { Kalduḳ hayāl-i yār ile vușlat muhạālmiş } \\
\text { Vuṣlat tașavvur itdigümiz bir ḩayālmiş }\end{array}$ & $\begin{array}{l}\text { Rag̉bet kemāle añlar-1duḳ şimdi Āzerēi } \\
\text { Cem -i menāl ü māl dah̆ı bir kemālmiş }\end{array}$ & gazel/5 & --. /..../.--./..-- & Başlık: Āžerī \\
\hline $44 \mathrm{a}$ & $\operatorname{Nev}^{\prime} \bar{i}$ & $\begin{array}{l}\text { Bülbüllere nāz it açılup söylemege sen } \\
\text { Ey ġonçe alayın haberüñ bād-1 seḥerden }\end{array}$ & $\begin{array}{l}\text { Müjgān-1 ġamuñ nice çeke hāțtır-1 Nev' } \overline{\mathrm{i}} \\
\text { Pürdür ġam ile şöyle ki șig̀maz ser-i sūzen }\end{array}$ & gazel/5 & --./.--./.--./.-- & Başlık: Nev`啇 \\
\hline $44 b$ & $\mathrm{Nev}^{\mathrm{i}} \overline{\mathrm{i}}$ & $\begin{array}{l}\text { Baḳma cemāl-i hūba hhaț-1 müşg-bārsuz } \\
\text { Çıḳmaz kitāb-1 mihr ü mahạabbet kenārsuz }\end{array}$ & $\begin{array}{l}\text { Nev` } \bar{i} \text { ḳanı zamānede bir ehl-i i` tibār } \\
\text { Olsa ‘aceb mi sözlerümüz i` tibārsuz }\end{array}$ & gazel/5 & --../-.-./.--./-..- & Başlık: Nev' $\bar{i}$ \\
\hline $44 b$ & $\mathrm{Nev}^{c} \overline{\mathrm{i}}$ & $\begin{array}{l}\text { Göreli rūyuñı șūretleri büt-huānelerüñ } \\
\text { Oldılar cümle senüñ yazılu divaānelerüñ }\end{array}$ & $\begin{array}{l}\text { 'Ömri her birisinüñ geçdi belā-keşlik ile } \\
\text { Nev'iyā zülfi girince eline şānelerüñ }\end{array}$ & gazel/5 & ..-- /..-- /..-- /...- & Başlık: Nev' $\overline{\mathrm{i}}$ \\
\hline $45 \mathrm{a}$ & Yahyā & $\begin{array}{l}\text { Düşmez ol şāha ki her gāh ider istig̀nā } \\
\text { Gāh olur 'āşıḳ-1 şeydāya düşer istiğnā }\end{array}$ & $\begin{array}{l}\text { Sitem ü cevri de Yahyā'ya tevāżūúc görinür } \\
\text { Gerçi her vaż` } 1 \text { gelür yāre nazarar istignnā }\end{array}$ & gazel/5 & ..-- /..-- /..-- /..- & Başlık: Yahyā \\
\hline $45 \mathrm{a}$ & Yaḥyā & $\begin{array}{l}\text { Țūụtīsșıat ol cāme-i sebzi giye cānā } \\
\text { Bir söz yiri var mı baḳa āyineye cānā }\end{array}$ & $\begin{array}{l}\text { Ey gam yidi vașạāf-1 lebüñ olalı Yahyaā } \\
\text { Țūți gibi şimden girü sükker yiye cānā }\end{array}$ & gazel/5 &.$--- / .--. / .---. / .--$ & Başlık: Yahyaā \\
\hline $45 b$ & Mis̄āli & $\begin{array}{l}\text { Ber-bād ola yoluñda ten-i hāa-sārumuz } \\
\text { Bir gün yir ile görmeye kimse ġubārumuz }\end{array}$ & $\begin{array}{l}\text { Nažm ehli ter düşüp yuya eş ārdan elin } \\
\text { Görse Mišāli bu gazel-i āb-dārumuz }\end{array}$ & gazel/5 & --./-.-./.--. /-.- & Başlık: Mis̄āli \\
\hline $45 b$ & Bāḳi & $\begin{array}{l}\text { Dilā meyl itme vașl-1 dil-rübāya } \\
\text { Hevā-y1 salțanat düşmez gedāya }\end{array}$ & $\begin{array}{l}\text { Ferāmūş it gam-ı devrānı Bākīi } \\
\text { Bugün sıḥhatdeyüz minnet Hudā'ya }\end{array}$ & gazel/5 & .---/.---/.-- & Başlık: Bāḳī \\
\hline $46 a$ & Bāḳi & $\begin{array}{l}\text { Cihān cevr ider derd-i ' 'ş̧̣uñla cāna } \\
\text { Seni sevmek oldı bahāne cihāna }\end{array}$ & $\begin{array}{l}\text { Demüñ 'ayşa șarf eyle Bāk̄ī niyāzuñ } \\
\text { Cevān-baht sultān-1 sāḥib-ḳırāna }\end{array}$ & gazel/5 & .-- / .-- / .-- /.-- & Başlık: Bāḳī \\
\hline $46 a$ & Bāḳi & $\begin{array}{l}\text { Seyr-i gülşende ne hāșsıl bile yār olmayıcak } \\
\text { Şāh-1 gülden ne biter tāze bahār olmayıcaḳ }\end{array}$ & $\begin{array}{l}\text { Bākìiyā şāhid-i makșūd olur çihre-nümā } \\
\text { Șāf u pāk āyine-i dilde gubār olmayıcaḳ }\end{array}$ & gazel/5 & ..-- /..-- /..-- /..- & Başlık: Bāḳī \\
\hline $46 b$ & Bāḳi & $\begin{array}{l}\text { Baḳmadı bāḡa göñül yār ile yār olmayıcak } \\
\text { Aḳmadı șu gibi gülzāra bahār olmayıcaḳ }\end{array}$ & $\begin{array}{l}\text { Olmaz ey Bāḳ̄ìi bì-dil ser-i a' dā pā-māl } \\
\text { Yine sen țab` semendine süvār olmayıcaḳ }\end{array}$ & gazel/7 & ..-- /..-- /...- /...- & Başlık: Bāḳī \\
\hline $46 b$ & Bāḳi & $\begin{array}{l}\text { Düssse göñlüm n'ola ol ḩançer-i hūn-efşāna } \\
\text { Müjen oḳlarınuñ eylükleri batdı cāna }\end{array}$ & $\begin{array}{l}\text { Cān nisāār eyledi Bāk̄ī bilini kuçmag̀ içün } \\
\text { Der-miyān itdi bugün varını dervişāāe }\end{array}$ & gazel/5 & ..-- /..-- /..-- /...- & Başlık: Bāḳi \\
\hline $47 a$ & Mis̄āli $\bar{i}$ & $\begin{array}{l}\text { Ey kaşı yā șanma tīrüñ cānuma kār eylemez } \\
\text { Kimseye hum-1 derūnum anı iẓhār eylemez }\end{array}$ & $\begin{array}{l}\text { Ey Missālī bir adım atmag̀a servüñ cānı yok } \\
\text { Anuñ içün yār ile gülşende reftār eylemez }\end{array}$ & gazel/5 & -.--/-.--/-..--/.-- & Başlık: Mis̄āli \\
\hline $47 a$ & Bāḳ̄i & $\begin{array}{l}\text { Maḥabbet husrev-i fermān-dih-i şāh u gedā ancak } \\
\text { Musahhhar cümle 'ālem '1ş̧̣a bir sırr-1 Hudā ancak }\end{array}$ & 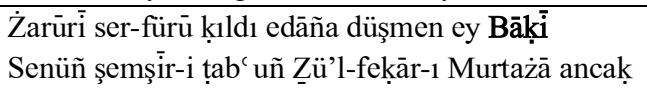 & gazel/7 & .---/.---/.---/.--- & Başlık: Bāḳi \\
\hline $47 b$ & Mis̄āli & $\begin{array}{l}\text { Derd-i dile la' lüñ gibi dermān ele girmez } \\
\text { Dermān degül ammā güzelüm cān ele girmez }\end{array}$ & $\begin{array}{l}\text { El üzre țutarlarsa Mișālīyi mahạaldür } \\
\text { Anuñ gibi bir rind-i suhan-dān ele girmez }\end{array}$ & gazel/5 & ---./.--./.--./.-- & Başlık: Mișāli \\
\hline
\end{tabular}




\begin{tabular}{|c|c|c|c|c|c|c|}
\hline $47 b$ & Mișāli & $\begin{array}{l}\text { Cemālüñ tābına şem` ü hilāl ebrūña 'āşıkdur } \\
\text { Birinüñ ḳaddi ḩam olmış birinüñ bağrı yanıḳdur }\end{array}$ & $\begin{array}{l}\text { Mis̄āli yāraşur mümtāz olursa ehl-i naẓm içre } \\
\text { Gören eş`ārını taḥsin ider fenninde fāyıḳdur }\end{array}$ & gazel/5 & .---/.---/.---/.--- & Başlık: Mișāli \\
\hline $48 \mathrm{a}$ & Mis̄āli $\bar{i}$ & $\begin{array}{l}\text { Tīìgı kaçan ki sinede zahmuñ ' ayān ider } \\
\text { Derd-i derūnı yāre o demde beyān ider }\end{array}$ & $\begin{array}{l}\text { Görse bilüñde ḩançer-i hūun-rīzüñi şehā } \\
\text { Cān naḳdini Mišālī o dem der-miyān ider }\end{array}$ & gazel/5 & --./-..-./.--. /-..- & Başlık: Mișāli \\
\hline $48 \mathrm{a}$ & Mis̄āli $\bar{i}$ & $\begin{array}{l}\text { Derildi Ka' be-i kūyuñda ḳullaruñ 'ibādet var } \\
\text { Kaşuñ miḥrābına ḳılmağa ḳılem secde niyyet var }\end{array}$ & $\begin{array}{l}\text { Teb-i mihr-i ruhıyla ḳatı yanġın gibi ol māhuñ } \\
\text { Mis̄ālī mihr-i ‘ālem-tābda gaāyet ḥarāret var }\end{array}$ & gazel/5 & .---/.---/.---/.--- & Başlık: Mișāli \\
\hline $48 b$ & Bāḳi & $\begin{array}{l}\text { Müje haylin dizer ol ġamze-i fettān șaf șaf } \\
\text { Gūyiyā cenge țurur nize-güzārān șaf șaf }\end{array}$ & $\begin{array}{l}\text { Ḳadrüñi seng-i mușallāda bilüp ey Bākīi } \\
\text { Ṭurup el bağlayalar ḳarşuña yārān șaf șaf }\end{array}$ & gazel/9 & ..-- /..-- /..-- /..- & Başlık: Bāḳī \\
\hline $48 b$ & Veysì & $\begin{array}{l}\text { Nāmeñe baḳmaduġına ol nigār-1 bī-vefā } \\
\text { Ey dil-i bī-çāre benden bir ḳulaç kāḡı̀d saña }\end{array}$ & & matla'/1 & -.--/-.---/-.--/-.- & Başlık: Veysi $\bar{i}$ \\
\hline $49 a$ & Mis̄āli & $\begin{array}{l}\text { Görinmezsin perīveş çekdürüp āvāreñe gamlar } \\
\text { Kanı ey cām 'ālemde senüñle sürdügüm demler }\end{array}$ & $\begin{array}{l}\text { Göñül naḳdine zülfi șarḳıcaḳ olmış ḳafā-dārı } \\
\text { Mišāli uç virüp başdan çıḳar āhir o perçemler }\end{array}$ & gazel/5 & .---/.---/.---/.--- & Başlık: Mis̄ālī \\
\hline $49 a$ & Sirri & $\begin{array}{l}\text { Şehā tīg-1 gamuñ kesmek dilermiş bendeñi senden } \\
\text { Beni ġam öldürür şimden girü ümmidi kes benden }\end{array}$ & $\begin{array}{l}\text { İrişdi şām-1 fürḳat gel bu günden ölmege sa' y it } \\
\text { Yitiş ser-menzile ey Surri bāri sen de erkenden }\end{array}$ & gazel/5 & .---/.---/.---/.--- & Başlık: Sırrī \\
\hline $49 b$ & Mis̄āli & $\begin{array}{l}\text { Ölümlü ‘āşıłka fürḳatde kūy-1 dil-rübā yigdür } \\
\text { Kişi gurbetde bīmār olıcaḳ dārü’ş-şifā yigdür }\end{array}$ & $\begin{array}{l}\text { Mišāli Ḥiżr elinden olsa da āb-1 hayāt içmez } \\
\text { Elüñden bir kadeh nūş eylemek ol mübtelā yigdür }\end{array}$ & gazel/5 & .---/.---/.---/.--- & Başlık: Mis̄ālī \\
\hline $49 b$ & Tīìi & $\begin{array}{l}\text { Ç1ḳarduñ ḩāk-i rāh-1 yārı seyl-i eşk ile başa } \\
\text { Benüm iki gözüm merdümlük itdüñ hayli çoḳ yaşa }\end{array}$ & $\begin{array}{l}\text { Leb-i dilber șafāsın Tīg̀iyā peymāne-keşden șor } \\
\text { Şarābuñ lezzzetin añlar o kim yār ola 'ayyāşa }\end{array}$ & gazel/5 & |---/.---/.---/.--- & Başlık: Tïgi \\
\hline $50 \mathrm{a}$ & Misāāli & $\begin{array}{l}\text { Pervāneveş bizüm de od olmazdı yirimüz } \\
\text { Nāz 1ssı olmasaydı o şem`-i münïrimüz }\end{array}$ & $\begin{array}{l}\text { Nażm ehli cümle fārig̀ olurdı nazīireden } \\
\text { Görse Mis̄āli bu gazel-i bi-naẓirimüz }\end{array}$ & gazel/5 & --. /-... /.--. /-..- & Başlık: Mișāli \\
\hline $50 \mathrm{a}$ & Misāāli & $\begin{array}{l}\text { Baḳmadı rūy-1 zerdüme dilber } \\
\text { Zere mā 'il degül o siminin-ber }\end{array}$ & $\begin{array}{l}\text { Düşdi ol şevḳ ile mey-i nāba } \\
\text { N'ola șıısa Mișāliyā sāğar }\end{array}$ & gazel/5 & ..--/.--./ ..- & Başlık: Mișāli \\
\hline $50 \mathrm{~b}$ & $\begin{array}{l}\text { Derviş } \\
\text { Çelebi }\end{array}$ & $\begin{array}{l}\text { Yār ser-keş sīne pür-āteş göñül sevdā-perest } \\
\text { Baht nā-hem-vār țālic ser-nigūn hnātı̣ şikest }\end{array}$ & $\begin{array}{l}\text { [Pençe-i kām-1 dil-i Derviş zīr-i dest-i gaam } \\
\text { Çāre ne meşhūrdur çün dest ber-bālā-yı dest] }\end{array}$ & gazel/5 & -.---/-.--/-.--/-.. & Başlık: Hāāi ${ }^{16}$ \\
\hline $50 \mathrm{~b}$ & Maḳāli & $\begin{array}{l}\text { Gūşında șanmañ ol șanemüñ gūş-vāredür } \\
\text { Pehlū-yı āfitābda ol bir sitāredür }\end{array}$ & $\begin{array}{l}\text { Āhum duhāān 'ālem-i ' 1şḳuñ sipihridür } \\
\text { Yir yir Maḳāli i aña kevākib şerāredür }\end{array}$ & gazel/5 & --. /-..-./.--. /-..- & Başlık: Maḳāli \\
\hline $51 \mathrm{a}$ & Bāḳi & $\begin{array}{l}\text { Nem-i eşkümle göñül dāg̀i dem-ā-dem tāze } \\
\text { Gül-i ruhsāruñ ile gülşen-i ‘ ālem tāze }\end{array}$ & $\begin{array}{l}\text { Olicak hūba göñül virmege 'irfān ehli } \\
\text { Şic r-i Bāḳi gibi hem şūh gerek hem tāze }\end{array}$ & gazel/5 & ..-- /..-- /..-- /..- & Başlık: Bāḳī \\
\hline $51 \mathrm{a}$ & Bāḳi & $\begin{array}{l}\text { Gümişden pāleheng ol nah̆l-i bālānuñ miyānında } \\
\text { Görinür māh-1 tābāndur nihāl-i serv yanında }\end{array}$ & $\begin{array}{l}\text { Görenler ol kemerde Bākiyā țāke-1 melāḥatde } \\
\text { Yazılmış şemsedür dirler güzellik āsumānında }\end{array}$ & gazel/5 & .---/.---/.---/.--- & Başlık: Bāḳī \\
\hline $51 \mathrm{a}$ & Bāḳi & Dergāh-1 Ḥaḳk’a derd ile ‘āşık niyāzda & Bāḳi ḳarin-i fürḳatüñ olmaḳ revā mıdur & gazel/5 & --./-..-./.--. /-..- & Başlık: Bāḳī \\
\hline
\end{tabular}

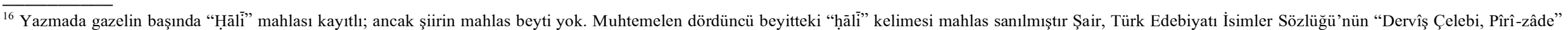
maddesinden (Yeniterzi 2014) tespit edilmiş, mahlas beyti buradan eklenmiştir. 


\begin{tabular}{|c|c|c|c|c|c|c|}
\hline & & Bāṭıl taṣavvur itmede zāhid namāzda & Akrān içinde böyle iken imtiyāzda & & & \\
\hline $51 \mathrm{a}$ & & $\begin{array}{l}\text { Dün gice girdi halkalka-i zikre o meh-liḳā } \\
\text { ' Āşșlarına döne döne eyledi cefā }\end{array}$ & & matla'/1 & --../-.../.--./..- & Başlık: Müfred \\
\hline $51 \mathrm{~b}$ & Bāḳi & $\begin{array}{l}\text { Gönül aḳdı gözüm yaşı gibi ol ḳadd-i dil-cūya } \\
\text { Niçün meyl itmez ol serv-i hırāmānum aḳar șuya }\end{array}$ & $\begin{array}{l}\text { Yine cisminde Bākīi hançerüñle yāreler çizdi } \\
\text { Șanasın sāde-rū bir dil-rübādur çekdi pehlūya }\end{array}$ & gazel/5 & ----/.--/.---/.--- & Başlık: Bāḳi \\
\hline $51 \mathrm{~b}$ & $\overline{\text { Āzeri }}$ & $\begin{array}{l}\text { Düşmeni terk itmegi ḳavl itdi ol peymānı süst } \\
\text { Ben didüm 'ahdüñ bütün mi didi kim terküm dürüst }\end{array}$ & & matla'/1 & -.--/-.---/-.--/-.- & Başl1k: Āzzerī \\
\hline $51 \mathrm{~b}$ & Bāḳi & $\begin{array}{l}\text { Zülfüñe bend eyle ben mecnūnı didüm dilbere } \\
\text { Didi ḳayd itdüm seni dīvāne geçdüñ deftere }\end{array}$ & $\begin{array}{l}\text { Șūret itdüñ şi' rüñi girdüñ nigāruñ göñline } \\
\text { Bāḳiyā bu nakș ile sen nükte ḳazduñ mermere }\end{array}$ & gazel/5 & -.--/-.---/-.--/-.- & Başlık: Bāḳi \\
\hline $51 \mathrm{~b}$ & & $\begin{array}{l}\text { Mihr ü mehdür șanmañuz devr eyleyen şām u seher } \\
\text { ' Āşık olmış çerh saña țurmayup gögsin döger }\end{array}$ & & matla'/1 & -.---/.---/-.---/..- & Başlık: Müfred \\
\hline $51 \mathrm{~b}$ & Bāḳi & $\begin{array}{l}\text { Niçe demdür șabr ider ol tịg̀-i bürrān zahmını } \\
\text { Şimdi ḳatlanmaz göñul şemşir-i hicrān zahmına }\end{array}$ & $\begin{array}{l}\text { Bākīiyi söyletmez olduñ lac lüñ aldı aġzına } \\
\text { Döymez ol nāzük lebüñ beñzer ki dendān zahmına }\end{array}$ & gazel/6 & -.--/-.---/..--/-.- & Başlık: Bāḳi \\
\hline $52 \mathrm{a}$ & Bāḳi & $\begin{array}{l}\text { Bir lebi gonçe yüzi gülzār dirseñ işte sen } \\
\text { Ḩār-1 gamda 'andelïb-i zār dirseñ işte ben }\end{array}$ & $\begin{array}{l}\text { Bākìiyā Ferhād ile Mecnūn-1 şeydādan bedel } \\
\text { 'Āşı̣̂-1 bí-șabr u dil kim var dirseñ işte ben }\end{array}$ & gazel/7 & -.---/.---/-.--/-.- & Başlık: Bāḳī \\
\hline $52 \mathrm{a}$ & Bāḳi & $\begin{array}{l}\text { Naġamāt eylemege başladı șanma anı sen } \\
\text { Ehl-i sūzuñ șanemā āteşin üfler ney-zen }\end{array}$ & $\begin{array}{l}\text { Bākìiye 'işret ü 'ayş itmege hecrüñde yiter } \\
\text { Nāle ney göz yaşı mey fikr-i vișālün gülşen }\end{array}$ & gazel/6 & ..-- /..-- /..-- /..- & Başlık: Bāḳi \\
\hline $52 \mathrm{a}$ & Bāḳi & $\begin{array}{l}\text { SSaçuñ zencīine bend it dil-i āvāre eglensün } \\
\text { Muḳayyed ḳ̂l biraz ol zülf-i müşgin-tāre eglensün }\end{array}$ & $\begin{array}{l}\text { Şarāb-1 dil-güşāa egler dil-i mehcūrı ey Bāk̄i } \\
\text { İlet ol derdmendi ḩāne-i hammāre eglensün }\end{array}$ & gazel/6 & .---/.---/.---/.--- & Başlık: Bāḳi \\
\hline $52 \mathrm{~b}$ & Bāḳi & $\begin{array}{l}\text { Ele cām-1 mușaffā al derūnuñ pür-ṣafā olsun } \\
\text { Ḥarīm-i bezmüñe tāb-1 mey-i rūşen żiyā olsun }\end{array}$ & $\begin{array}{l}\text { Nišār itdümse hāk-i dergehinden gaayra ey Bākì } \\
\text { Cihānda lü 'lü'-i menşūr-1 naẓmum hep hebā olsun }\end{array}$ & gazel/5 & .---/.---/.---/.--- & Başlık: Bāḳī \\
\hline $52 \mathrm{~b}$ & Bāḳi & $\begin{array}{l}\text { Şeb-i zülfüñ nihān eyle ruhuñ rūşen bahār olsun } \\
\text { Gider ebr-i hațuñ yüzden cemālüñ nev-bahār olsun }\end{array}$ & $\begin{array}{l}\text { Cenāb-1 şāha ey Bākīi nișār it lü 'lü'-i nazmuñ } \\
\text { Bu șandūḳ-1 șadef-kāride dürr-i şāh-vār olsun }\end{array}$ & gazel/7 & .---/.---/.---/.--- & Başlık: Bāḳi \\
\hline $52 \mathrm{~b}$ & Bāḳi & $\begin{array}{l}\text { Niçe bir mübtelā-yı '1şḳa hicrānı belā olsun } \\
\text { İlāhi kendü gibi bī-vefāya mübtelā olsun }\end{array}$ & $\begin{array}{l}\text { Yine Bāk̄ịi vișālüñ günlerin görsün gözüm nūrı } \\
\text { Gubār-1 āsitānuñ çeşm-i cāna tūtiyā olsun }\end{array}$ & gazel/5 & .---/.---/.---/.--- & Başlık: Bāḳi \\
\hline $53 a$ & Bāḳi & $\begin{array}{l}\text { İtdürür zühhāda ol miḥrāb-1 ebrū ser-fürū } \\
\text { Kildurur ' uşşāḳa ol ḩāk-i ser-i kū ser-fürū }\end{array}$ & $\begin{array}{l}\text { Dürr-i nazmuñ Bākìiā baş egdürür țāliblere } \\
\text { Kim żarūi itdürür ġavvāṣa lü 'lü' ser-fürū }\end{array}$ & gazel $/ 5$ & -..---.---/-.--/-.- & Başlık: Bāḳi \\
\hline $53 a$ & Bāḳi & $\begin{array}{l}\text { Ol āfitāb-țal' ata kim dirse māh-rū } \\
\text { Olsun cihānda meh gibi dā 'im siyāh-rū }\end{array}$ & $\begin{array}{l}\text { Kūyuñ yolında Bākīi-i üftāde var iken } \\
\text { Hayfā o keff-i pāye süre hāāk-i rāh rū }\end{array}$ & gazel/5 & --./-.-./.--. /-.- & Başlık: Bāḳi \\
\hline $53 a$ & Bāḳi & $\begin{array}{l}\text { Saña kūyuñ içre olana ḳarīn } \\
\text { Melek hem-nişin ü felek şeh-nişin }\end{array}$ & $\begin{array}{l}\text { Șorarsañ ḳapuñda şehā Bākīìi } \\
\text { Ġulām-1 kemin bende-i kemterin }\end{array}$ & gazel $/ 5$ & .--/.--/.--/.- & Başlık: Bāḳi \\
\hline $53 \mathrm{~b}$ & Bāḳi & $\begin{array}{l}\text { Bāg̀ pür-nakşs u nigār oldı bahārı severin } \\
\text { Mā'ilem nakşsına gāyetde nigārı severin }\end{array}$ & $\begin{array}{l}\text { 'Āşıkuñ rakșda hem-pālarıdur dest-efşān } \\
\text { Bāḳiyā anuñ içün serv ü çenārı severin }\end{array}$ & gazel/5 & ..-- /..-- /..-- /...- & Başlık: Bāḳ̄i \\
\hline
\end{tabular}




\begin{tabular}{|c|c|c|c|c|c|c|}
\hline $53 b$ & Bāḳi & $\begin{array}{l}\text { Seyre çıkssun ne temāşā ola peydā göresin } \\
\text { Bir iki gün hele șabr eyle temāşā göresin }\end{array}$ & $\begin{array}{l}\text { Bākịyā cilve ḳlur çihre-i iḳbāl ol dem } \\
\text { Ki göñül āyinesin pāk ü mücellā göresin }\end{array}$ & gazel/7 & ..-- /..-- /..-- /..- & Başlık: Bāḳ̄i \\
\hline $53 b$ & Bāḳi & $\begin{array}{l}\text { Pervāne gibi şu' le-i şevküũñle yanmadın } \\
\text { 'Āşș maḥabbet adın añar mı utanmadın }\end{array}$ & $\begin{array}{l}\text { Kesb-i hevā-y1 'sşk idegör Bākịāa hemān } \\
\text { Dil hānesine revzen-i dīdeñ ḳapanmadın }\end{array}$ & gazel/5 & --./-..-/.--.//.-- & Başlık: Bāḳī \\
\hline $54 a$ & Bāḳi & $\begin{array}{l}\text { Māh-rūlar bí-` aded bir ' àşık-1 sevdāyi ben } \\
\text { Yitmeye biñ pāre ḳ1lsam bu dil-i şeydāyı ben }\end{array}$ & $\begin{array}{l}\text { Āsitān-1 yārda mesken bulursam Bākiyā } \\
\text { Kāfda seyr itdürem 'ankāya istignnāyı ben }\end{array}$ & gazel/6 & -.---/.---/-.--/-.- & Başlık: Bāḳi \\
\hline $54 a$ & Bāḳ̄i & $\begin{array}{l}\text { Dil çeker ol tār-1 mūy-1 ' anberīnüñ minnetin } \\
\text { İstemez ‘ālemde zülf-i hūur-1 ' 'inüñ minnetin }\end{array}$ & $\begin{array}{l}\text { Silk-i gevher ma'nī-i bārīk ü nażm-1 ter yiter } \\
\text { Bāḳiyā çekmez göñül dürr-i șeminüñ minnetin }\end{array}$ & gazel/6 & -.--/-.--/-.---/-.- & Başlık: Bāḳī \\
\hline $54 a$ & Bāḳi & $\begin{array}{l}\text { Niçe țūfān oldı peydā dīde-i hūn-pāşdan } \\
\text { Nūh çeşmüm yanına gelse dem urmaz yaşdan }\end{array}$ & $\begin{array}{l}\text { Bākīiyi ġam öldürür ' } 1 \text { şḳuñ yolında korḳarın } \\
\text { Şimdi mi çekdi belāyı rāh-rev yoldaşdan }\end{array}$ & gazel/5 & -.---/-.--/-..--/-.- & Başlık: Bāḳī \\
\hline $54 b$ & Yahyā & $\begin{array}{l}\text { Cānā ḩaț-1 yāḳūtı yazan ol dehen üzre } \\
\text { Bir noḳța ḳomış surh ile gūyā zekẹan üzre }\end{array}$ & $\begin{array}{l}\text { Yaḥyā o şehüñ cevherīi-i lac lini söylet } \\
\text { Yāḳūtı neden kim țuta dürr-i ` Aden üzre }\end{array}$ & gazel/5 & --./.--./.--../.-- & Başlık: Yaḥyā \\
\hline $54 b$ & 'Āli & $\begin{array}{l}\text { Hुāk-i derüñi devlet-i dārāya degişmem } \\
\text { Her na' lçeñüñ resmini țuğraya degişmem }\end{array}$ & $\begin{array}{l}\text { Cānānuma bir kerre nazaar ḳılmag̀a ‘ } \bar{A} l \bar{i} \\
\text { Dünyā gibi biñ țurfe temāşāya degişmem }\end{array}$ & gazel/7 & --./.--./.--./.--- & Başlık: ‘ Āli \\
\hline $54 b$ & Rūḥi & $\begin{array}{l}\text { Husşt-i haremin mesned-i ‘ ̇̇sā'ya degişmem } \\
\text { Huâk-i ḳademin ‘ālem-i bālāya degişmem }\end{array}$ & $\begin{array}{l}\text { Rūḥ̄i ruh̆ı fikriyle iki hāvere baḳmam } \\
\text { Bu maḳta's ol maḳtac-i garrāya degişmem }\end{array}$ & gazel/7 & --./.--./.--./.--- & Başlık: Rūhīi \\
\hline $55 \mathrm{a}$ & Rūḥi & $\begin{array}{l}\text { Yār gaāill çerh zālim derd ü miḥnet bir degül } \\
\text { Dil ża ìif ac dā ḳavi renc ü meşaḳḳat bir degül }\end{array}$ & $\begin{array}{l}\text { Söz bilen bir bilmez erbāb-1 kelāmı Rūhiyāā } \\
\text { Gerçi birdür vezn-i țab ammā belāgāat bir degül }\end{array}$ & gazel/7 & -.--/-.--/-..--/-.- & Başlık: Rūḥi \\
\hline $55 \mathrm{a}$ & Bāḳ̄i & $\begin{array}{l}\text { Zülfüñi görsem ‘izāruñ üzre ey hụur-1 cemīl } \\
\text { Șanuram cennetde țgigān eylemişdür Selsebil }\end{array}$ & $\begin{array}{l}\text { Muntazır olsa n’ola nergis gubār-1 kūyına } \\
\text { Tūtiyāya Bāḳiyā muhtāc olur 'ayn-1 'alīl }\end{array}$ & gazel/5 & -.--/-.---/-.--/-.- & Başlık: Bāḳi \\
\hline $55 \mathrm{a}$ & Bāḳ̄i & $\begin{array}{l}\text { Derd ü gam bezmine ḳaddüm gibi bir çeng olmaz } \\
\text { Nāylar nālelerüm sāzına āheng olmaz }\end{array}$ & $\begin{array}{l}\text { Āl ile ruhlaruñ alsun dil-i Bāk̄īyi hemān } \\
\text { Aña ey şūh-1 cihān böyle güzel reng olmaz }\end{array}$ & gazel/5 & ..-- /..-- /..-- /..- & Başlık: Bāḳī \\
\hline $55 \mathrm{~b}$ & Yahyā & $\begin{array}{l}\text { Şeh-bāz gözüñ ṣayd-1 dil ü cāna șalınsun } \\
\text { Fitrākuña ḳo bu dil-i divāane șalınsun }\end{array}$ & $\begin{array}{l}\text { Yahyāa yine bir hūù zuhūr eyledi dirler } \\
\text { Bir tāze belādur yine yārāne șalınsun }\end{array}$ & gazel/5 & ---./.--./.--./.-- & Başlık: Yaḥyā \\
\hline $55 \mathrm{~b}$ & Nādirī & $\begin{array}{l}\text { Ġam-1 '1şḳuñla feryād eylesem dīvānedür dirler } \\
\text { Ḳızarsa ağlamaḳdan gözlerüm mestānedür dirler }\end{array}$ & $\begin{array}{l}\text { Ne deñlü tiş̧e ursañ anda genc-i '1şk olup peydā } \\
\text { Derūnı Nādirì'nüñ bir ' aceb vỉrānedür dirler }\end{array}$ & gazel/5 & .---/.---/.---/.--- & Başlık: Nādirīi ${ }^{17}$ \\
\hline $55 \mathrm{~b}$ & Yahyā & $\begin{array}{l}\text { 'Aklum dağıdur zülf-i siyeh-kār-1 perisşān } \\
\text { Cem'iyyet-i hāatı̣ mı ḳor efkār-1 perişān }\end{array}$ & $\begin{array}{l}\text { Her gūşede şi` rüñ oḳınur var ise Yahyā } \\
\text { Söyletdi o kākül saña eş ār-1 perişşān }\end{array}$ & gazel/5 & --./.--./.--../.-- & Başlık: Yaḥyā \\
\hline $56 a$ & Yahyā & $\begin{array}{l}\text { Bilsem ki sīne yārelerinden o yāre ne } \\
\text { Çekmek görindi ey dil-i bī-çāre çāre ne }\end{array}$ & $\begin{array}{l}\text { 'İd irdi naḳd-i cāna ise hīç revāc yok } \\
\text { Yahyyā ne ḥāżır eyledüñ ol gül-‘ izāare ne }\end{array}$ & gazel/5 & --. /-... /.--. /-..- & Başlık: Yaḥyā \\
\hline $56 a$ & Yahyā & $\begin{array}{l}\text { Cūy-1 eşküm serv ḳaddüñçün ke aḳsun sū-be-sū } \\
\text { Būstān-1 kūyuñ arayı țolansun kū-be-kū }\end{array}$ & $\begin{array}{l}\text { Ġonçedur gülzār-1 derd ü gamda Yahyānuñ hemān } \\
\text { Jeng-beste göñli tāze dāğgarla tū-be-tū }\end{array}$ & gazel/5 & -.--/-.---/-.--/-.- & Başlık: Yaḥyā \\
\hline
\end{tabular}

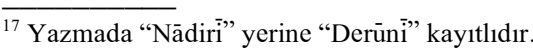




\begin{tabular}{|c|c|c|c|c|c|c|}
\hline $56 a$ & Yahyā & $\begin{array}{l}\text { Kanlu peykānı ki bu sīne-i ‘ uryāna çıḳa } \\
\text { Beñzer ol gonçe-i nev-resteye dükkāna çıḳa }\end{array}$ & $\begin{array}{l}\text { Reh-i `1şḳındayuz ol serv-kadüñ ey Yaḥyā } \\
\text { Korḳaruz kim yolumuz vādī-i hicrāna çıḳa }\end{array}$ & gazel/5 & ..-- /..-- /..-- /..- & Başlık: Yahyā \\
\hline $56 \mathrm{~b}$ & Yahyāā & 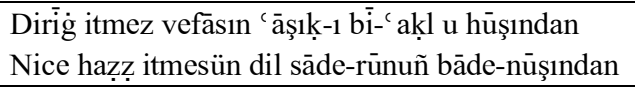 & $\begin{array}{l}\text { Alur biñ cān ile naḳd-i revāna 'āḳıbet Yaḥyā } \\
\text { Lebüñ ḳandini bāzār-1 vefā sükker-fürūşından }\end{array}$ & gazel/5 & .---/.---/.---/.--- & Başlık: Yaḥyā \\
\hline $56 \mathrm{~b}$ & Yahyāā & $\begin{array}{l}\text { Yaḳlaşdı diyü hațtııı geçme o güzelden } \\
\text { Kim gördi ki evvel öle bir kimse ecelden }\end{array}$ & $\begin{array}{l}\text { Yārüñ ki miyānındadur ol ḩançer-i gaddār } \\
\text { Şimden girü Yaḥyā geçemezsin sen o belden }\end{array}$ & gazel/5 & --./.--./.---./.-- & Başlık: Yahyyā \\
\hline $56 b$ & Yahyāā & $\begin{array}{l}\text { Bir güzel sev kim aña her nev-cevān reşk eylesün } \\
\text { Cān gibi síneñde yir itsün cihān reşk eylesün }\end{array}$ & $\begin{array}{l}\text { Çeşme-i ḥayvānuñ ag̉zı șuyın aḳıtsun sözüñ } \\
\text { Ḥıżr işitsün anı Yahyyā her zaman reşk eylesün }\end{array}$ & gazel/5 & -.--/-.---/-.--/-.- & Başlık: Yahyā \\
\hline $57 \mathrm{a}$ & Yahyyā & $\begin{array}{l}\text { Münevver țal' at-i ferḩundesi bir hūbdur bayram } \\
\text { Güneş yüzlü hilāl ebrūlu bir maḥbūbdur bayram }\end{array}$ & $\begin{array}{l}\text { Seḥer yazmag̀ içün evșāf-1 Sultān Aḥmed'i Yahyyā } \\
\text { Güneşden zer varak peydā ider zer-kūbdur bayram }\end{array}$ & gazel/5 & .---/.---/.---/.--- & Başlık: Yaḥyā \\
\hline $57 \mathrm{a}$ & Yahyāā & $\begin{array}{l}\text { Şive-i reftārūññ serv-i çemende görmedük } \\
\text { Bu ser-āmed ḳāmeti bir nārvende görmedük }\end{array}$ & $\begin{array}{l}\text { Şerh iderse ders-i ' } 1 \text { şḳı yine Yahyyā şerh ider } \\
\text { Bir maḥal kalmış mıdur zīāā bu fende görmedük }\end{array}$ & gazel/5 & -.--/-.---/-.--/-.- & Başlık: Yaḥyā \\
\hline $57 \mathrm{a}$ & Yahyāā & $\begin{array}{l}\text { 'Ayn-1 żillet mi degül devlet-i dünyā didügüñ } \\
\text { Kaț̣ alçak görinür oldı eñ a' lā didügüñ }\end{array}$ & $\begin{array}{l}\text { Hazer it seng-i cefāsından o şūhunuñ dirdüñ } \\
\text { 'Āḳıbet geldi benüm başuma Yaḥyā didügüñ }\end{array}$ & gazel/5 & ..-- /..-- /..-- /..- & Başlık: Yaḥyā \\
\hline $57 b$ & Yahyāā & $\begin{array}{l}\text { Șalınsun 'īd irişdi yine hūūbānı Sitanbūl'uñ } \\
\text { Yine ārāste olsun ḳaramanı Sitanbūl'uñ }\end{array}$ & 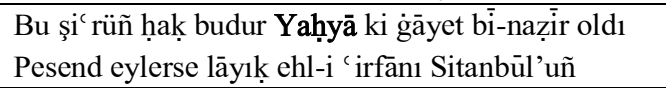 & gazel/5 & .---/.---/.---/.--- & Başlık: Yahyā \\
\hline $57 \mathrm{~b}$ & Yahyā & $\begin{array}{l}\text { Sürersin dā 'im ey dil pāy-1 yāre çihre-i zerdüñ } \\
\text { Dimez mi ol țabīb-i cān u dil saña nedür derdüñ }\end{array}$ & $\begin{array}{l}\text { Felek döne döne şimdi cefālar itsün ey Yahyyā } \\
\text { Ne tozlar ḳopara bir dem ola āh-1 cihān-gerdüñ }\end{array}$ & gazel/5 & |---/.---/.---/.--- & Başlık: Yahyā \\
\hline $57 b$ & Yahyāā & $\begin{array}{l}\text { Ġamze özler dil yā kākül ikiden hālì degül } \\
\text { Tỉ̀g özler cān yā gull ikiden hāali degül }\end{array}$ & $\begin{array}{l}\text { Yā irem ḳaddine Yahyyā yāhud olam pāy-māl } \\
\text { Yā teraḳkī yā tenezzül ikiden ḩāli degül }\end{array}$ & gazel/5 & -.---/.---/-.--/-.- & Başlık: Yahyā \\
\hline $58 \mathrm{a}$ & Yahyāā & $\begin{array}{l}\text { Umulmaz mı o țıfl-1 şūhudan şeftālūler virmek } \\
\text { Cihānda şimdi mi oldı nihāl-i tāze ber virmek }\end{array}$ & $\begin{array}{l}\text { İşitme nuşh u pendin şeyh-i şehrüñ tācını terk it } \\
\text { Ne lāzım kendüñe bi-hūde Yahyyā derd-i ser virmek }\end{array}$ & gazel/5 & |---/.---/.---/.--- & Başlık: Yahyā \\
\hline $58 \mathrm{a}$ & Yahyāā & $\begin{array}{l}\text { Sen ḳariñ-i şem }-i \text { meclis ben habībümden raḳ } \\
\text { Bir midür pervāne sūz-1 vașl ile sūz-1 firāk }\end{array}$ & $\begin{array}{l}\text { Kalmasun Yaḥyā ten-i fersūdede yoldaşdan } \\
\text { Kūy-1 yāre gitmege cān u dil itmez ittifāḳ }\end{array}$ & gazel/5 & -.--/-.---/.---/-.- & Başlık: Yaḥyā \\
\hline $58 \mathrm{a}$ & Yahyāā & 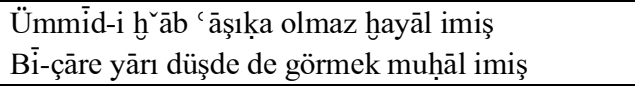 & $\begin{array}{l}\text { Dermān olursa senden olur ey țabīb-i cān } \\
\text { Yaḥyā-yı hyaste-hāāl 'aceb bì-mecāl imiş }\end{array}$ & gazel/5 & --./-..-./.--./-..- & Başlık: Yahyā \\
\hline $58 \mathrm{~b}$ & Yahyāā & $\begin{array}{l}\text { Bülbül şețāreti gül-i handānı güldürür } \\
\text { Taḳlid-i zāg kebk-i ḩrāmānı güldürür }\end{array}$ & $\begin{array}{l}\text { Yahyyāyı ag̉ladursa eger yār gaam degül } \\
\text { Müşkil budur ki düşmen-i nādānı güldürür }\end{array}$ & gazel/5 & --. /-..-./.--. /-..- & Başlık: Yahyā \\
\hline $58 \mathrm{~b}$ & Yahyā & $\begin{array}{l}\text { Rūy-1 dilber al kāgaza ' anberīn mū anda haṭ } \\
\text { Sāyesi müjgānınuñ i` rāb beñlerdür nuḳaṭ }\end{array}$ & $\begin{array}{l}\text { Yazılurdı hāațır-1 mecrūḥ-1 Yahyā dōstum } \\
\text { Kātib-i vașfuñ ideydi üstüh̆̌ānından mıḳaṭ }\end{array}$ & gazel/5 & -.---/-.--/-.---/..- & Başlık: Yahyā \\
\hline $58 \mathrm{~b}$ & Maḳāili & $\begin{array}{l}\text { Nihāl-i ḳāmet-i mevzūnı yāruñ nahll-i dil-cūdur } \\
\text { Dil-i meyyālümüz ardınca anuñ bir aḳar șudur }\end{array}$ & $\begin{array}{l}\text { Ug̉urlar hānümānın kimse țuymaz hāne-i dilden } \\
\text { Maḳālì gamze-i dilber 'acāyib düzd-i uğrudur }\end{array}$ & gazel/5 & .---/.---/.---/.--- & Başlık: Makāli \\
\hline $59 \mathrm{a}$ & Yahyā & Seyr-i gülşende iken yār büyüklenme iñen & Yār Yahyāya dimiş vaḳt-i gül ü bülbüldür & gazel/5 & ..-- /..-- /..-- /..- & Başlık: Yaḥyā \\
\hline
\end{tabular}




\begin{tabular}{|c|c|c|c|c|c|c|}
\hline & & Hele her cānibi bir yoḳlaya ey serv-i çemen & Șubh-dem 'azm idelüm gülşene bir ben bir sen & & & \\
\hline $59 a$ & Yaḥyā & $\begin{array}{l}\text { Aḳıtdum yaşumı yaḳdum fitīl-i dāḡ-1 sūzānı } \\
\text { Benem şimdi maḩabbet bezminüñ şem -i şebistānı }\end{array}$ & $\begin{array}{l}\text { Kemān u tïr ü hançer cem in eyler țurmaz ey Yahyā } \\
\text { Yine bir fitne peydā itmek ister çeşm-i fettānı }\end{array}$ & gazel/5 & .---/.---/.---/.--- & Başlık: Yaḥyā \\
\hline $59 a$ & Yaḥyā & $\begin{array}{l}\text { 'Aks-i müjgān ile ey dilber-i şīīn-harekāàt } \\
\text { Șanuram ruhlaruñ i' rāb ḳonılmış āyāt }\end{array}$ & $\begin{array}{l}\text { Dāhil it silsile-i zülfüñe gel Yahyaāyı } \\
\text { Līk şol şarț ile şāhum ki ola ḳayd-1 ḥayāt }\end{array}$ & gazel/5 & ..-- /..-- /..-- $/ . .-$ & Başlık: Yahyāā \\
\hline $59 b$ & Yaḥyā & $\begin{array}{l}\text { Çeşm-i hūnininüm hayālüñ şāhını i' zāz ider } \\
\text { Her gelişde bir ḳumāş-1 sürh pāy-endāz ider }\end{array}$ & $\begin{array}{l}\text { Az çoḳ neylerse Yahyyā luțílur iḥsānıdur } \\
\text { Dime ol meh-rū cefāyı çoḳ vefāyı az ider }\end{array}$ & gazel/5 & -.--/-.---/-.--/-.- & Başlık: Yaḥyā \\
\hline $59 b$ & Yaḥyā & $\begin{array}{l}\text { Mu' ațar ḳ̂l meşāmum būy-1 zülf-i müşk-bāruñla } \\
\text { Münevver ḳıl dü çeşmüm mihr-i rūy-1 tāb-dāruñla }\end{array}$ & $\begin{array}{l}\text { Dimezsin k̦anda ahş̧amlar o meh dahı uyursın sen } \\
\text { Uyutmazsin egerçi halḳı Yahyā āh u zāruñla }\end{array}$ & gazel/5 & .---/.---/.---/.--- & Başlık: Yaḥyā \\
\hline $59 \mathrm{~b}$ & Yaḥyā & $\begin{array}{l}\text { Hulḳa hạalḳa zülfi dām u iki hāli iki zāg } \\
\text { Murg-1 dil șayd itmege beñ gösterüp kurmaḳ duzag̀ }\end{array}$ & $\begin{array}{l}\text { Meclis olmaz kim o şāh içün yanup yaḳılmaya } \\
\text { İltifāt idüp n'ola Yaḩyā'yı eylerse çerāg }\end{array}$ & gazel/5 & -.---/.---/-.--/-.- & Başlık: Yaḥyā \\
\hline $60 \mathrm{a}$ & Yaḥyā & $\begin{array}{l}\text { 'Aks-i rūyuñla derūnum tābnāk olmaḳdadur } \\
\text { Söz hemān āyīne-i idrāk-i pāk olmaḳdadur }\end{array}$ & $\begin{array}{l}\text { Korḳarın derd-i derūnum ide yir yirden zuhūr } \\
\text { Tìंḡ-1 gamla sīne Yahyāa çāk çāk olmaḳdadur }\end{array}$ & gazel/5 & -.--/-.---/-.--/-.- & Başlık: Yaḥyā \\
\hline $60 \mathrm{a}$ & Yaḥyā & $\begin{array}{l}\text { Feryādum irdi göklere ey serv-ḳad yitiş } \\
\text { Korḳum budur bu gam beni alur meded yitiş }\end{array}$ & $\begin{array}{l}\text { Yașdansun āsitānumı vaṣl isteyen dimiş } \\
\text { Yahyyā işigi țaşını idin sened yitiş }\end{array}$ & gazel/5 & --./-.-. /.--./-.- & Başlık: Yaḥyā \\
\hline $60 \mathrm{a}$ & Maḳāīi & $\begin{array}{l}\text { Başladı Ferhād-1 dil ḳazmag̉a miḥnet sengini } \\
\text { Gel gör ey şīrin-dehen țag ile țaşuñ cengini }\end{array}$ & $\begin{array}{l}\text { Meh beyāżında Makālī şol sevāduñ ' aynıdur } \\
\text { Her ḳaçan țaḳınsa ol meh țurra-i şeb-rengini }\end{array}$ & gazel/5 & -.--/-.---/-.--/-.- & Başlık: Maḳāli \\
\hline $60 \mathrm{~b}$ & Vahịidi & $\begin{array}{l}\text { Kıldı ruhsarında yāruñ hạalḳa-i zülfi karār } \\
\text { Oldı mir’āt içre gūyā ' aks-i çeşmüm āşikār }\end{array}$ & 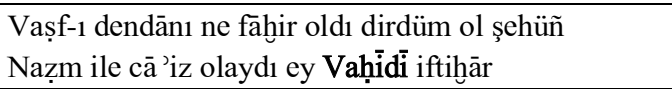 & gazel/5 & -.--/-.---/-.--/-.- & Başlık: Vahịidi \\
\hline $60 \mathrm{~b}$ & & $\begin{array}{l}\text { Söyleşilmezse ‘aceb mi leb-i handānuñ ile } \\
\text { Bağladuñ dilleri hep zülf-i perişānuñ ile }\end{array}$ & & matla'/1 & ..-- /..-- /..-- /..- & Başlık: Ferd \\
\hline $60 \mathrm{~b}$ & & $\begin{array}{l}\text { Didi Loḳmān ki kirās oldı çü emrāz-1 beden } \\
\text { Ben anı reng ü letāfetde 'aḳiḳ olsa yimen }\end{array}$ & & matla'/1 & ..-- /..-- /..-- /..- & Başlık: Ferd \\
\hline $60 \mathrm{~b}$ & Yahyyā & $\begin{array}{l}\text { Dilüñ bir kez șınuk mir āatine baḳdı yüzin dürdi } \\
\text { Tecellā-yı cemālin var ise dildār çoḳ gördi }\end{array}$ & $\begin{array}{l}\text { Hele rūz-1 su 'āl olsun da görsün yār Yaḥyāyı } \\
\text { Ne bir dem yüzine baḳdı ne bir kez hāạtırın șordı }\end{array}$ & gazel/5 & .---/.---/.---/.--- & Başlık: Yahyā \\
\hline $61 \mathrm{a}$ & Nādirīi & $\begin{array}{l}\text { Yaḳınca lāle meş` al șaldı tāb-1 ' ālem-efrūzı } \\
\text { Meger kim oldı ḳır-1 dāg̀-1 dil sermāye-i sūzı }\end{array}$ & $\begin{array}{l}\text { Hezāra Nādirī yanında rāz-1 '1ş̧̣ı söyletme } \\
\text { Getürme șeyh-i fennüñ bahṣsine țfl-1 nev-āmūzı }\end{array}$ & gazel/10 & .---/.---/.---/.--- & $\begin{array}{l}\text { Başlik: Nādirī Efendi } \\
\text { sellemellāhü }\end{array}$ \\
\hline $61 \mathrm{a}$ & Yahyyā & $\begin{array}{l}\text { Āsīb-i hazān bilmez '1şḳuñ gül-i gülzārı } \\
\text { Bülbülleri bu bāḡuñ her demde ider zārı }\end{array}$ & $\begin{array}{l}\text { Yaḥyāda reh-i '1şkuñ bārına taḥammül yok } \\
\text { Bir menzile irişdür ey ḳudreti çoḳ Bārī }\end{array}$ & gazel/5 & ---./.------./.--- & Başl1k: Yahyyā \\
\hline $61 b$ & Yahyāā & $\begin{array}{l}\text { Eyle merdümlük sevād-1 çeşmümi ey eşk-i āz } \\
\text { Yāre ‘ arż eyle süveydā-yı̀ dilüñ ḥālin biraz }\end{array}$ & $\begin{array}{l}\text { Ders-i '1ş̧̧uñ müşkilin Yahyā nice hall eylesün } \\
\text { Söyleyenler kendüsin bilmez bilenler söylemez }\end{array}$ & gazel/5 & -.---/-.--/-.---/..- & Başlık: Yaḥyā \\
\hline $61 b$ & Yaḥyā & $\begin{array}{l}\text { Bir āfet-i devrān yine araladı şehri } \\
\text { Hercāyiligi mihr gibi meh gibi şehri }\end{array}$ & $\begin{array}{l}\text { Yahyyā işimüz itdi bizüm şükr ü şikāyet } \\
\text { La' l-i lebinüñ gamzesinüñ luṭf ile ḳahrı }\end{array}$ & gazel/5 & ---./.--./.--./.-- & Başlık: Yaḥyā \\
\hline
\end{tabular}




\begin{tabular}{|c|c|c|c|c|c|c|}
\hline $61 b$ & Hāletī & $\begin{array}{l}\text { Țag̉ıtdı 'aḳlumı seyr idicek zülf-i perişānuñ } \\
\text { Bıraḳdum kendümi cānā görüp çāh-1 zenahăānuñ }\end{array}$ & $\begin{array}{l}\text { Açılmaz gonçe-i bahtuñ senüñ ey Ḩāleti hergiz } \\
\text { Meger ki pertev-i mihri șala ol mihr-i rahş̧ānuñ }\end{array}$ & gazel/5 & .---/.---/.---/.--- & $\begin{array}{l}\text { Başl1k: ‘Azmi-zāde } \\
\text { Efendi }\end{array}$ \\
\hline $62 \mathrm{a}$ & Bāḳi & $\begin{array}{l}\text { Biñ mübtelāyı miḥnet ile bir dem öldürür } \\
\text { Dilber mülāyim olmayıcaḳ ādem öldürür }\end{array}$ & $\begin{array}{l}\text { Bāḳ̄i peleng-i kūh-1 gamuñ pençesindedür } \\
\text { Luṭuñ meded yitişmez ise bir dem öldürür }\end{array}$ & gazel/5 & --. /-... /.--. /-..- & Başlık: Bāḳi \\
\hline $62 \mathrm{a}$ & Hādī & $\begin{array}{l}\text { Dil-i nā-şādumı lutff-1 firāvānuñla şād eyle } \\
\text { Dem-ā-dem zulmı ḳānūn itme şāhum gāhi dād eyle }\end{array}$ & $\begin{array}{l}\text { Cefā 'add eylemez Hādī ne deñlü eyleseñ düşnām } \\
\text { Ne dirseñ luțf u iḥsānuñ hemān dünyāda yād eyle }\end{array}$ & gazel/5 & .---/.---/.---/.--- & Başlık: Hādī \\
\hline $62 b$ & Vahịidi & 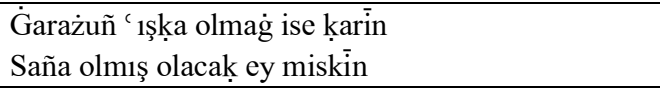 & $\begin{array}{l}\text { Ey Vahīidi çeker mi hāar elemin } \\
\text { Bāig-1 vușlatdan olmayan gül-çīn }\end{array}$ & gazel/6 & ..-- /.-.- /..- & Başlık: Li-muharririhi \\
\hline $62 b$ & Vahīid & $\begin{array}{l}\text { Gūş it peyām-1 lac l-i dehen söylerem saña } \\
\text { Benden işit bu rāzı ki ben söylerem saña }\end{array}$ & $\begin{array}{l}\text { Medḥ itdügüm ḳadar o meh-i bī-bedel Vahīi } \\
\text { Çı̣̣mazsa alma vechi ḥasen söylerem saña }\end{array}$ & gazel/6 & --./-... /.--. /-..- & Başlık: Vahịid \\
\hline $62 b$ & Vahịid & $\begin{array}{l}\text { Baḳ ebruvān-1 yāre kemān söylerem saña } \\
\text { Tīr-i nigāhı țoz koparan söylerem saña }\end{array}$ & & matla'/1 & --./-..-./.--. /-..- & Başlık: Vahịid \\
\hline $62 b$ & Vahịid & $\begin{array}{l}\text { Baḳ ḳadd-i yāre serv-i çemān söylerem saña } \\
\text { Hüsnin tamām cümleten ān söylerem saña }\end{array}$ & $\begin{array}{l}\text { Nażm-1 Vahīid olur ise taḥsinüñe ḳarīn } \\
\text { Şic r-i selis-i şevḳ-resān söylerem saña }\end{array}$ & gazel/7 & --../..-./.--./..- & Başlık: Vahīi \\
\hline $63 \mathrm{a}$ & 'Ațāyì & $\begin{array}{l}\text { Göñül bağlar gören ol kākül-i pür-tābdan geçmez } \\
\text { Baḳup zülf-i nigāra sünbül-i sìr-ābdan geçmez }\end{array}$ & $\begin{array}{l}\text { Göñül bir iki peymāne çeker gāhī hakikimāne } \\
\text { Muhașșsal ey ‘Ațāyī dil şarāb-1 nābdan geçmez }\end{array}$ & gazel/5 & .---/.---/.---/.--- & Başlık: 'Ațāyī \\
\hline $63 a$ & & $\begin{array}{l}\text { Giceler kākül-i sevdāsı ile dildāruñ } \\
\text { Ḥaddi pāyānı mı var țūl-i dırāz efkāruñ }\end{array}$ & $\begin{array}{l}\text { Jāleler țamlamag̀ ister gül-i terden gūyā } \\
\text { Görinen hatț-1 bināgūş degüldür yāruñ }\end{array}$ & gazel/5 & ..-- /..-- /..-- /..- & Başlık: Gazel \\
\hline $63 b$ & $\operatorname{Şem}^{\prime} \bar{i}$ & $\begin{array}{l}\text { Alursa cānumı gamzen n'ola ömrüm revān olsun } \\
\text { İçerse leblerüñ ḳanum efendi nūş-1 cān olsun }\end{array}$ & $\begin{array}{l}\text { Oñulmaz derdümüñ dāg̀ yüri ‘ arż eyle dildāra } \\
\text { Niçe bir sinede Şem`‘் bu göynükler nihān olsun }\end{array}$ & gazel/5 & .---/.---/.---/.--- & Başlık: Şem`i $\bar{i}$ \\
\hline $63 b$ & & $\begin{array}{l}\text { Var mı bir hāṭtır ki gaamdan hāār huāli olmaya } \\
\text { Kanı bir ruh kim havādișden gubārı olmaya }\end{array}$ & & matla'/1 & -.--/-.---/-.--/-.- & Başlık: Müfred \\
\hline $63 b$ & & $\begin{array}{l}\text { Var mı bir ruhssāre kim zülf-i siyeh-fām olmaya } \\
\text { Devr içinde ḳanḳı gün gördüñ ki ahşşam olmaya }\end{array}$ & & matla'/1 & -.---/.---/-.--/-.- & Başlık: Müfred \\
\hline $63 b$ & & $\begin{array}{l}\text { Sen lebi āb-1 hayātı ḳoçan ölmez dirler } \\
\text { 'Ahdüm olsun seni cānā ḳocayın ölmez isem }\end{array}$ & & müfred/1 & ..-- /..-- /..-- /..- & Başlık: Müfred \\
\hline $63 b$ & & $\begin{array}{l}\text { Göñlüm aldı nāz ile bir gözleri ala yine } \\
\text { Gözleri alalaruñ cānlar fidā alayına }\end{array}$ & & matla'/1 & -.--/-.---/-.--/-..- & Başlık: Müfred \\
\hline $63 b$ & & $\begin{array}{l}\text { Müjeler tîr-i belā ḳavs-i kuzuah ebrūlar } \\
\text { Ādemi nice helāk eylemesün meh-rūlar }\end{array}$ & & matla'/1 & ..-- /..-- /..-- /..- & Başlık: Müfred \\
\hline $64 a$ & Yahyā & $\begin{array}{l}\text { Birbirine girdiler țūlāblarla āblar } \\
\text { Āblar gālib olınca döndiler țūlāblar }\end{array}$ & $\begin{array}{l}\text { Pertev-i ruhsāā-1 sāḳi şu' le-i cām-1 şarāb } \\
\text { 'Ayşa āgāa eyle Yaḥyā geçmedin meh-tāblar }\end{array}$ & gazel/5 & -.--/-.---/-.--/-.- & $\begin{array}{l}\text { Başlık: Yaḥyā Efendi } \\
\text { Sellemellāhu }\end{array}$ \\
\hline $64 \mathrm{a}$ & Zihni & İñleyüp dūlābveş dökdüm gözümden āblar & Bu gazael ' 1 ḳd-1 dür-i dendān-1 dilber vașfidur & gazel/5 & -.---/-.---/-.--/-.-- & Başlık: Nazịire-i Zihni \\
\hline
\end{tabular}




\begin{tabular}{|c|c|c|c|c|c|c|}
\hline & & Döndürince ol mehi ḳurdum niçe dūlāblar & Az olur Zihni bu resme gevher-i nā-yāblar & & & \\
\hline $64 b$ & 'Abdi & $\begin{array}{l}\text { Gözlerüm dìdār-1 yāre ḳarşu dökse āblar } \\
\text { Ol dem ol āba olur her bir müjem mízāblar }\end{array}$ & $\begin{array}{l}\text { Sim-tenler bāb-1 vașlın șāḥib-i māla açar } \\
\text { Müflise ‘Abdī açıllmaz şimdi bil ol bāblar }\end{array}$ & gazel/5 & -.--/-.---/-.--/-.- & Başlık: Nazīire-i 'Abdi \\
\hline $64 b$ & Yahyā & $\begin{array}{l}\text { Díde hūun-1 dille pür oldukçca eşk-i ter döker } \\
\text { Ag̀lamaḳdan gayrı dermān bulımaz ölçer döker }\end{array}$ & $\begin{array}{l}\text { Bir ' aceb vādīye șaldı hüsn-i bī-pervā beni } \\
\text { Aña 'anḳā-yı hyayāl uğrarsa Yahyā per döker }\end{array}$ & gazel/5 & -.--/-.---/-.--/-.- & Başlık: Yahyā Efendi \\
\hline $65 \mathrm{a}$ & Raḥmi & $\begin{array}{l}\text { Sīneye yāre çeküp yārüñ eli kan old } 1 \\
\text { Bahr-i hūn içre o dem pençe-i mercān oldı }\end{array}$ & $\begin{array}{l}\text { Dil-i Rahmīide ḳarār itmedüñ ey genc-i murād } \\
\text { Y1llar oldı ki anuñ hyāțır virān oldı }\end{array}$ & gazel/5 & ..-- /..-- /..-- /..- & Başlık: Raḥmi ${ }^{18}$ \\
\hline $65 \mathrm{a}$ & $\mathrm{Nev}^{c} \overline{\mathrm{i}}$ & $\begin{array}{l}\text { Yüzüñ döndürme bizden ey felek senden recāmuz yoḳ } \\
\text { Keder bulduḳ senüñ ` ayşüñnde nūşuñda șafāmuz yoḳ }\end{array}$ & 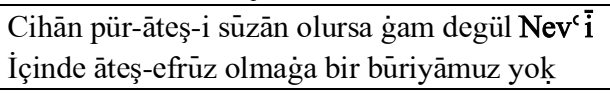 & gazel/5 & .---/.---/.---/.--- & Başlık: Nev'部 \\
\hline $65 b$ & Fevrí & $\begin{array}{l}\text { Bir dem ki ben faḳị̂r idüm ol yār-1 cān idi } \\
\text { Sāḳi idi ki nāzük idi nükte-dān idi } \\
\text { Yārān idi ki her biri rind-i cihān idi } \\
\text { Devrān-1 lāle idi dem-i gülsitān idi } \\
\text { Hengām-1 ' ayş ü vaktt-i mey-i erḡuvān idi } \\
\text { Şevke-i cevānlar ile göñül kām-rān idi } \\
\text { Demler o demler idi zamān ol zamān idi }\end{array}$ & $\begin{array}{l}\text { Ey Fevrỉ gibi mīhnet-i eyyāma mübtelā } \\
\text { Devr-i şebābı eyleme żāyi` șatup riyā } \\
\text { Ālām-1 pīīi eylemedin ḳaddüñi dü-tāā } \\
\text { 'İşretler eyle dehrden al kām sür șafāa } \\
\text { Şāyed müsā' id olmaya bu devr-i bī-vefā } \\
\text { Añup bu demleri diyesin bir zamān ola } \\
\text { Demler o demler idi zamān ol zamān idi }\end{array}$ & müsebba $/ 7$ & --. /-... /.--. /-..- & $\begin{array}{l}\text { Başlık: Müsebbac }{ }^{-1} \\
\text { Fevri Efendi }{ }^{19}\end{array}$ \\
\hline $66 \mathrm{a}$ & Zātí & $\begin{array}{l}\text { Dem-be-dem seylābveş eşk-i revānum çaǵlar } \\
\text { Dögünüp țaşlarla ağlar ḥălüme ırmaġlar }\end{array}$ & $\begin{array}{l}\text { [Zātiyā Ferhād içün tagilarda feryād eyledüm } \\
\text { İşidüp feryādum gögsin geçürdi țaǵlar] }\end{array}$ & Gazel /5 & -.--/-.---/.---/-.- & \\
\hline $66 \mathrm{a}$ & & 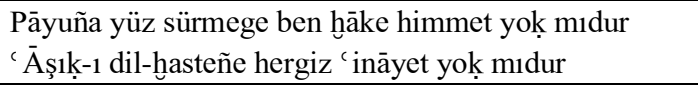 & $\begin{array}{l}\text { Öldürürsin hecr ile ben ‘āşıłı ey dil-rübā } \\
\text { Ḳāżí olmaz mı Huudā yarın ḳıāmet yoḳ mıdur }\end{array}$ & $\operatorname{nazım} / 2$ & -.--/-.---/-.--/-.- & Başlık: Penc-gāh \\
\hline $66 \mathrm{a}$ & & $\begin{array}{l}\text { Ețrāf-1 çemenzārı yine āb țolandı } \\
\text { Gülzāra girüp her yaña șalındı bulandı }\end{array}$ & $\begin{array}{l}\text { Beñzetdi dehānuñda olan ḥabb-1 nebāta } \\
\text { Şeb-nem göricek gonçelaruñ aġzı șulandı }\end{array}$ & nazım/2 & ---./.--./.--./.-- & Başlık: Nevā \\
\hline $66 b$ & Celāli $\bar{i}$ & $\begin{array}{l}\text { Nev-bahār oldı bezendi bāğ u șaḥrā bir yaña } \\
\text { Seyr-i iḳdām eyledi a' lā vü ednā bir yaña } \\
\text { Çekmedi sensüz göñül ey serv-i bālā bir yaña } \\
\text { Cümle ‘ālem bir yaña bī-çāre tenhā bir yaña } \\
\text { Cennet-i kūyuñ ḳomazam olsa dünyā bir yaña }\end{array}$ & 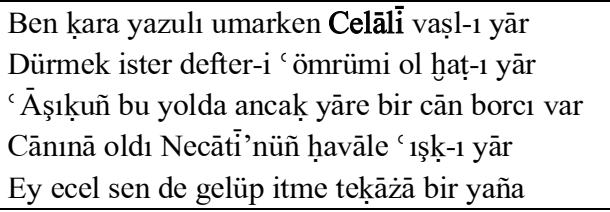 & tahmis/7 & -.--/-.---/-.--/-.- & Başlık: Celāli ${ }^{21}$ \\
\hline $67 \mathrm{a}$ & & $\begin{array}{l}\text { Dil hnānesini ug̣rı gözüñ ḳıldı ḳarārgāh } \\
\text { Deldi sīnemi tỉr-i müjeñ itdi güzergāh }\end{array}$ & $\begin{array}{l}\text { Öldürdi beni ḩışm ile mestāne gözüñ āh } \\
\text { Raḥm eyle benüm hālüme luṭf eyle Ḥasan Şāh }\end{array}$ & nazım/2 & --./.---./.--./.-- & $\begin{array}{l}\text { Başlık: Nevā-yı } \\
\text { sünbüle }\end{array}$ \\
\hline
\end{tabular}

${ }^{18}$ Yazmada başlı "Hālì" şeklinde kayıtlıdır.

${ }^{19}$ Yazmada başlık "Muhammes-i Fevrì Efendi" şeklinde kayıtlıdır.

${ }^{20}$ Yazmada sadece iki beyti bulunan șiir Zâtî Dîvânı'nda (Tarlan 1967: I/163) beș beyitlik gazel șeklinde yer almaktadır. Mahlas beyti dîvândan yazılmıștır.

${ }^{21}$ Yazmada başlık "Necātî" şeklinde kayıtlıdır. 


\begin{tabular}{|c|c|c|c|c|c|c|}
\hline $67 a$ & Bāḳi & $\begin{array}{l}\text { Nām u nişāne ḳalmadı fașl-1 bahārdan } \\
\text { Düşdi çemende berg-i dıraht i i tibārdan }\end{array}$ & $\begin{array}{l}\text { Bāḳ̄i çemende hayli perişān idi varaḳ } \\
\text { Beñzer ki bir şiḳāyeti var rūzgārdan }\end{array}$ & gazel/5 & --./-..-./.--./-..- & Başlık: Bāḳ̄i \\
\hline $67 \mathrm{a}$ & Bāḳi & $\begin{array}{l}\text { Tesellī virmez ey dil derdüñi cānāne söylersin } \\
\text { Açılmaz saña gūyā gonçe-i handāne söylersin }\end{array}$ & 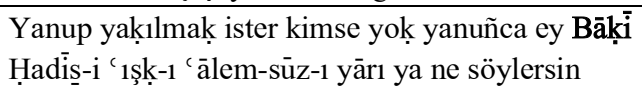 & gazel/5 & & Başlık: Bāḳī \\
\hline $67 \mathrm{~b}$ & Bāḳi & $\begin{array}{l}\text { Çāk oldı yakam cevr-i firāvānuñ elinden } \\
\text { Șad pāre iken dāmen-i dil anuñ elinden }\end{array}$ & $\begin{array}{l}\text { Bākīi niçe bir făh̆teveş bāḡ-1 belāda } \\
\text { Nālān olam ol serv-i hyıāmānuñ elinden }\end{array}$ & gazel/7 & --./.--./.--./.-- & Başlık: Bāḳi \\
\hline $67 \mathrm{~b}$ & Bāḳ̄i & $\begin{array}{l}\text { Dil-rübālarla 'aceb keșreti var her yoluñ } \\
\text { Geçemez hūblarından gönül İstanbūl'uñ }\end{array}$ & $\begin{array}{l}\text { Yoluña Bākīi-i dil-haste revān eyler idi } \\
\text { Tuhfe-i cān-1 ḥaḳir olsa eger maḳbūlüñ }\end{array}$ & gazel $/ 5$ & ..-- /..-- /..-- /..- & Başlık: Bāḳi \\
\hline $68 \mathrm{a}$ & Mihri Hātūn & $\begin{array}{l}\text { Yok șanurdum 'ālem içre cān ile serden lezīiz } \\
\text { Hey neler varmış cihānda dahı anlardan lezizz }\end{array}$ & 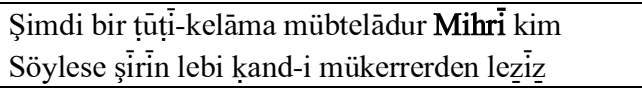 & gazel $/ 5$ & -.--/-.---/-.--/-..- & $\begin{array}{l}\text { Başlık: Ġazel-i Mihrī } \\
\text { Hātūn }\end{array}$ \\
\hline $68 \mathrm{a}$ & Șādıḳ & $\begin{array}{l}\text { Kūh-1 gamda dil-i Ferhād'umuzı yād eyle } \\
\text { Acı ey husrev-i şirīn-dehenüm dād eyle }\end{array}$ & $\begin{array}{l}\text { Varuñı virdi hevā yile gerek ey Șādık } \\
\text { Def gibi síneñi dög ney gibi feryād eyle }\end{array}$ & gazel $/ 5$ & ..-- /..-- /..-- /..- & Başlık: Gazel-i Șādık \\
\hline $68 b$ & $\operatorname{San}^{\prime}<\bar{i}$ & $\begin{array}{l}\text { Müdāmī ġayrılarla bāde-i gülgūn idersin sen } \\
\text { Șurāhị gibi bezm-i gamda bağrum hūn idersin sen }\end{array}$ & $\begin{array}{l}\text { Şifā-sāz ol kerem ḳıl Sā‘ īyi cevrüñle öldürme } \\
\text { Güzeller şāhısın ḳan itmegi ḳānūn idersin sen }\end{array}$ & gazel/5 & .---/.---/.---/.--- & Başlık: Ġazel-i Sāc $\bar{i}$ \\
\hline $68 b$ & Zāāti & 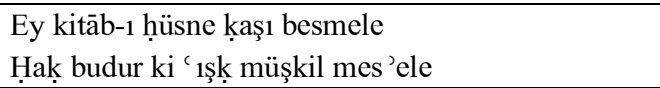 & $\begin{array}{l}\text { Tuhfe iltüñ Zāāti-i dil-hasteyi } \\
\text { Ol țabīb-i cāna şāyed hoş gele }\end{array}$ & gazel/5 & -.---/.---/-.-- & Başlık: Zātī \\
\hline $69 a$ & Necātī & $\begin{array}{l}\text { Lāle-ḩadler yine gülşende neler itmediler } \\
\text { Servi yürütmediler ġonçeyı söyletmediler }\end{array}$ & $\begin{array}{l}\text { Ey Necātī yüri șabr eyle elüñden ne gelür } \\
\text { Hūblar cevr ü cefāyı kime ögretmediler }\end{array}$ & gazel $/ 5$ & ..-- /..-- /..-- /..- & Başlık: Ġazel-i Necāti \\
\hline $69 a$ & Bahārí & 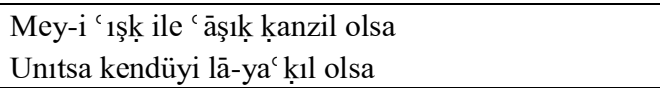 & $\begin{array}{l}\text { Dükenmez ḳsșsa-i derd-i Bahārī } \\
\text { Ki anuñ her güni ger biñ yıl olsa }\end{array}$ & gazel $/ 5$ & .---/.---/.-- & Başlık: Bahārī \\
\hline $69 b$ & Niḳābi & $\begin{array}{l}\text { Būseñe dil kāāni` olmaz vașlıñuñ şeydāsıdur } \\
\text { Dōstūm ma' zūur țut dünyā țama' dünyāsıdur }\end{array}$ & $\begin{array}{l}\text { Bilmek isterseñ Niḳābī kim-durur ol gononçe-leb } \\
\text { Gülsitān-1 hüsnüñüũ bir bülbül-i gūyāsıdur }\end{array}$ & gazel/5 & -.---/.---/-.--/-.-- & Başlık: Niḳābi \\
\hline $69 b$ & Emri & $\begin{array}{l}\text { Görindi ‘ aks-i rūy-1 yār mir 'āt-1 semenlerde } \\
\text { Zuhūr itdi ḩrām-1 ḳadd-i dilber nārvenlerde } \\
\text { Oturma merdüm-i çeşmüm gibi beytü'l-ḥazenlerde } \\
\text { Bahār oldı șafā kesb idicek demdür çemenlerde } \\
\text { Hușūșā șalına yanuñca serv ü sīm-tenler de }\end{array}$ & 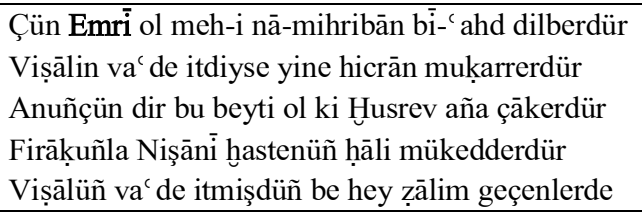 & tahmis/6 & .---/.---/.---/.--- & $\begin{array}{l}\text { Başlık: Ġazel-i Nişāni } \\
\text { Tahmis-i Emri }\end{array}$ \\
\hline $70 a$ & Fażlí & $\begin{array}{l}\text { Kanadum altına 'ank̦ā gibi biñ kūhsār aldum } \\
\text { İçinde pençe-i ḳahr ile kebk-i dil-figār aldum } \\
\text { Mahạabbet fāḳınuñ gerçi şikārın bī-şümār aldum } \\
\text { 'Adū-yı zāg elinden bir tezerv-i şivekār aldum } \\
\text { Dahı ben şāh-bāz-1 '1şḳ olaldan bir şikār aldum }\end{array}$ & $\begin{array}{l}\text { Olup Fażlī gibi ser-geştesi bir māh ruhsāruñ } \\
\text { Varup dellāl-1 dil bāzār-1 kūyına o dildāruñ } \\
\text { Hezārān derd ile iḳārını aldum ol aġyāruñ } \\
\text { Nukūd-1 șabrumı virdüm metā‘ -1 vașlına yāruñ } \\
\text { Görenler Zāàtiyā cānlar deger bir yādigār aldum }\end{array}$ & tahmis $/ 5$ & .---/.---/.---/.--- & $\begin{array}{l}\text { Başlık: Ġazel-i Zāti } \\
\text { Tahmis-i Fażli }\end{array}$ \\
\hline $70 \mathrm{~b}$ & Raḥmi & $\begin{array}{l}\text { Baña bir gūşe mi var künc-i fenādan ġayrı } \\
\text { Baña maḥrem kim olur derd ü ‘ anādan ġayrı }\end{array}$ & $\begin{array}{l}\text { Raḥmiyā virmeyicek yār bize vușlat elin } \\
\text { Virmeye şāhid-i makșūd bize devlet elin }\end{array}$ & tahmis $/ 5$ & ..-- /..-- /..-- /..- & $\begin{array}{l}\text { Başlık: Ġazel-i Necāti } \\
\text { Beg Tahmis-i Raḥmi }\end{array}$ \\
\hline
\end{tabular}

SEFAD, 2017 (38): 211-264 


\begin{tabular}{|c|c|c|c|c|c|c|}
\hline & & $\begin{array}{l}\text { Ger șorarlarsa dilā bunca belādan ġayrı } \\
\text { Dime kim yārda yoḳ cevr ü cefādan ġayrı } \\
\text { Ne dilerseñ bulınur mihr ü vefādan gayrı }\end{array}$ & $\begin{array}{l}\text { Āh u zār ile urup birbirine hayret elin } \\
\text { N'ola țutarsa Necātí yüzine haclet elin } \\
\text { Nesi var yüze gelür dest-i du'ādan gayrı }\end{array}$ & & & Efendi $\bar{i}$ \\
\hline $71 b$ & Hayāli $\bar{i}$ & 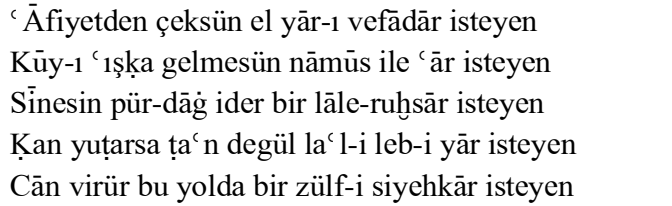 & 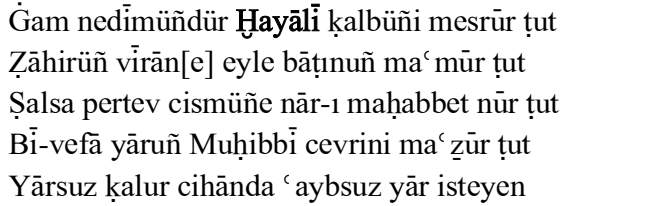 & tahmis/5 & -.--/-.---/-.--/-.-- & $\begin{array}{l}\text { Başlık: Gazel-i Sulțān } \\
\text { Süleymān Tahmís-i } \\
\text { Hayāli Beg }\end{array}$ \\
\hline $72 a$ & 'Ulvī & 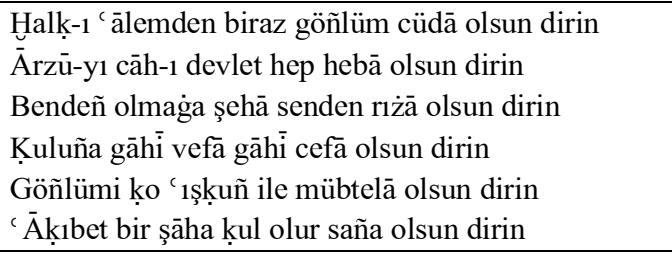 & 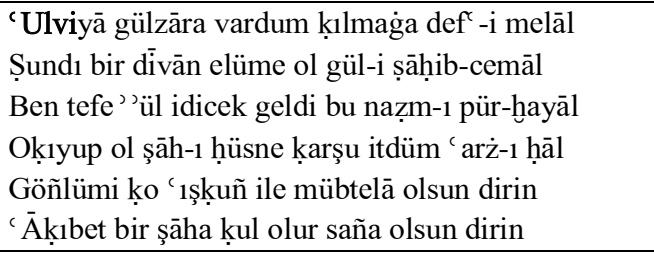 & müseddes/5 & -.---/.---/-.---/..- & Başlık: 'Ulvī \\
\hline $72 b$ & Raḥmi & $\begin{array}{l}\text { Cihān gark-āà olupdur dīde-i eşk-i revānumdan } \\
\text { Felekler nīl-reng olmış-durur dūd-1 duhānumdan } \\
\text { Melekler bāl ü per yaḳmış-durur sūz-1 nihānumdan } \\
\text { Düşelden ayru şeydā-dil meh-i nā-mihribānumdan } \\
\text { Kevākib her gice yummaz gözin āh u fiḡānumdan }\end{array}$ & 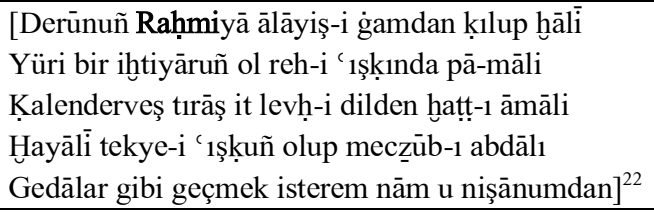 & tahmis $/ 5$ & .---/.---/.---/.--- & $\begin{array}{l}\text { Başlık: Ġazel-i Hayāli } \\
\text { Tahmis-i Raḥmí }\end{array}$ \\
\hline $73 a$ & Cinānī & 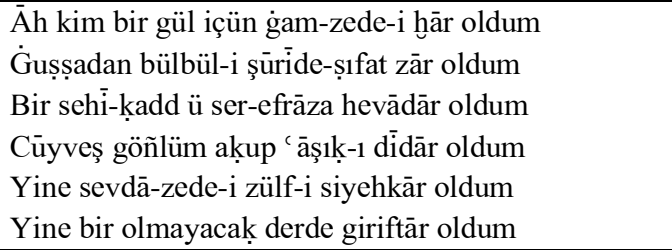 & $\begin{array}{l}\text { Ey Cinānī n'ola bülbül gibi nālān olsam } \\
\text { Gül-i șad-pāre gibi n'ola perişāan olsam } \\
\text { Țuyulup ' 'ş̧k ile ‘ ālemlere destān olsam } \\
\text { Kākül-i yār gibi n'ola perīşān olsam } \\
\text { Yine sevdā-zede-i zülf-i siyehkār oldum } \\
\text { Yine bir olmayacaḳ derde giriftār oldum }\end{array}$ & müseddes/6 & ..--/..-- /..--/..- & $\begin{array}{l}\text { Başlık: Cinānī } \\
\text { Fermāyed }\end{array}$ \\
\hline $74 a$ & Hayāli $\bar{i}$ & $\begin{array}{l}\text { Cānuña āteş urur mihr-i dırahssānuñ mı var } \\
\text { Sīnede dāğ-1 ġamından nār-1 sūzānuñ mı var } \\
\text { Șubḥ-dem şebnem döker bir çeşm-i giryānuñ mı var } \\
\text { N'olduñ iñlersin felek hercāyì cānānuñ mı var } \\
\text { Her maḳāmı seyr ider bir māh-1 tābānuñ mı var }\end{array}$ & 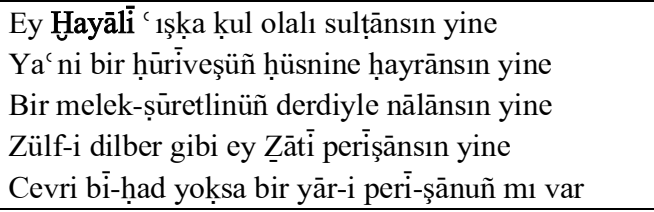 & tahmis $/ 5$ & -.---/.---/-.--/-.-- & $\begin{array}{l}\text { Başlık: Ġazel-i Z̄āti } \\
\text { Taḩmis-i Hayāli }\end{array}$ \\
\hline $74 b$ & Șabrì & $\begin{array}{l}\text { Dilā mecnūn-șıłfat ‘āşık olup gel olma dīvāne } \\
\text { Gider ol çeşm-i āhū yaña ola meyli yabana }\end{array}$ & $\begin{array}{l}\text { Mahạabbet derdi gibi bir dahı̂ renc ü ' } 1 \text { nā olmaz } \\
\text { Ki zirā dem ki bir maḥbūbda mihr [ü] vefā olmaz }\end{array}$ & tahmis $/ 5$ & |---------------- & $\begin{array}{l}\text { Başlık: Gazel-i Nev'ci } \\
\text { Tahmisis-i Șabri }\end{array}$ \\
\hline
\end{tabular}

${ }^{22}$ Yazmada dört bendi kayıtlı olan şiirin son bendi Bursalı Rahmî Dîvânı'ndan (Erdoğan 2011: 276) tamamlanmıştır. 


\begin{tabular}{|c|c|c|c|c|c|c|}
\hline & & $\begin{array}{l}\text { Biliş olma o cānān ile kim meyl ide nā-dāna } \\
\text { Gönül virme gözüñden dūr olan her māh-1 tābāna } \\
\text { Naẓar ḳılma saña yüz virmeyen mihr-i dırahşāna }\end{array}$ & 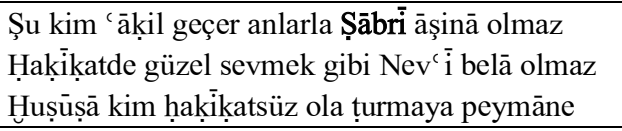 & & & \\
\hline $75 a$ & Ușūli & $\begin{array}{l}\text { Gerçi zencīir-i ser-i zülfüñe çoḳdur şeydā } \\
\text { Delü göñlüm gibi yoḳ vādī-i gamda tenhā }\end{array}$ & $\begin{array}{l}\text { Kaldı hecr ile cehennemde Ușūlī miskīn } \\
\text { Cennet-i vașla eger irmez ise vāy saña }\end{array}$ & gazel/5 & ..-- /..-- /..-- /..- & Başlık: Ușūli \\
\hline $75 b$ & Hayāli & $\begin{array}{l}\text { Ne zillet virmege rāḡg } ı \text { ne devlet-h̆̄āhumuz vardur } \\
\text { Ko ġayrı ġayra yār olsun bizüm Allāhumuz vardur }\end{array}$ & $\begin{array}{l}\text { Hुayāāi șūret-i dünyāya ġāfiller gibi baḳmaz } \\
\text { Ḥaḳị̣at vechine baḳmış dil-i āgāhumuz vardur }\end{array}$ & gazel/5 & .---/.---/.---/.--- & Başlık: Hayāli \\
\hline $75 b$ & $\mathrm{Nev}^{\prime} \overline{\mathrm{i}}$ & $\begin{array}{l}\text { Meclisde öpüp lac lini rindāna țuyurma } \\
\text { Ol ḥāleti aġzuñdaġ1 dendāna țuyurma }\end{array}$ & $\begin{array}{l}\text { Mey içme güzel sevme dimezler saña } \mathrm{Nev}^{`} \overline{\mathrm{i}} \\
\text { Ol żevḳi hemān zümre-i nādāna țuyurma }\end{array}$ & gazel/5 & --./.--./.--./.-- & Başl1k: Nev' $\overline{\mathrm{i}}$ \\
\hline $76 a$ & Riyāżī & $\begin{array}{l}\text { Ney gibi iñlersin ey dil mübtelālıḳ var gibi } \\
\text { Bir şeker-leb şūh dilberden cüdālı̣ var gibi }\end{array}$ & $\begin{array}{l}\text { Nükteñi ' aks eylemişler haylī reng almış ' adū } \\
\text { Ey Riyāżīi şā' ir-i rengīn-edālıḳ var gibi }\end{array}$ & gazel/5 & -.---/.---/..--/-.- & Başlık: Riyāżīi \\
\hline $76 a$ & Emri & $\begin{array}{l}\text { Kaşlaruñ ser-nāme-i hüüsnine yāruñ hạal çeker } \\
\text { Kill ḳalemlerle aña kākülleri cedvel çeker }\end{array}$ & $\begin{array}{l}\text { Z̄erre deñlü Emriyā hnāțı-perişāan olma kim } \\
\text { Ehl olan çekmez cihānuñ gușșasın cāhil çeker }\end{array}$ & gazel/5 & -.--/-.---/-.--/-.- & Başlık: Emrī \\
\hline $76 b$ & Kabūlī & $\begin{array}{l}\text { Ol ki māha nūr tevcīh eylemiş rū ḳoymış ad } \\
\text { Nūrdan bir nūn peydā itmiş ebrū ḳoymış ad }\end{array}$ & 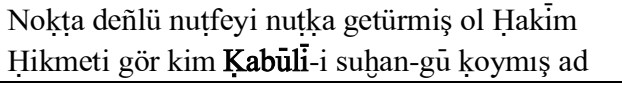 & gazel/7 & -.--/-.---/-.--/-.- & Başlık: Kabūlī \\
\hline $76 b$ & Nevālī & $\begin{array}{l}\text { 'Aks-i nihāl-i kaddüñ bāg̀-1 cinān içinde } \\
\text { Resm-i elif gibidür nakşs oldı cān içinde }\end{array}$ & 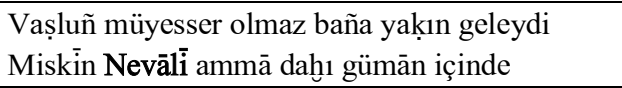 & gazel/5 & --. /-..- /--. /-.-- & Başlık: Nevāli Efendi \\
\hline $77 \mathrm{a}$ & Emri & $\begin{array}{l}\text { Leblerüñ gonçe yañagiuñ gül-i handān olmış } \\
\text { Ḥüsnüñ ey serv-i sehỉ tāze gülistān olmış }\end{array}$ & $\begin{array}{l}\text { Ḥasret-i lac lüñ ile cān virür Emrī șanemā } \\
\text { Gözlerüm ḳan aḳıdur üstine hayrān olmış }\end{array}$ & gazel/5 & ..-- /..-- /..-- /..- & Başlık: Emrī \\
\hline $77 \mathrm{a}$ & Senā'i & $\begin{array}{l}\text { Hुat çıkdı velī olmadı mihri ruhı zā 'il } \\
\text { Hurşididi cihān-tāba semā olmadı ḥā'il }\end{array}$ & $\begin{array}{l}\text { İḳlim-i suhanda geze erbāb-1 ma 'āni } \\
\text { Bulmaya Senā'ìye mu'ādil şeh-i 'ādil }\end{array}$ & gazel/7 & --./.---./.--./.-- & Başlık: Senā'̄i \\
\hline $77 b$ & Rūḥi & $\begin{array}{l}\text { Șanmañuz rüsvāylıḳdan gam çeker ferzāneyüz } \\
\text { Țaşa çalmış şişe-i nāmūsı bir dīvāneyüz }\end{array}$ & $\begin{array}{l}\text { Rūhiyā ẓarfi olan gelsün șalādur 'āleme } \\
\text { Biz mey-i vaḥdetle māl-ā-māl bir ḩum-ḩāneyüz }\end{array}$ & gazel/7 & -.---/.---/-.--/-.-- & Başlık: Rūḥī \\
\hline $77 b$ & $\mathrm{Nev}^{\mathrm{i}} \overline{\mathrm{i}}$ & $\begin{array}{l}\text { Ne mümkin oldı gaam-1 fürḳatüñle ülfet idem } \\
\text { Ne çāre var țalebüñden senüñ ferāgagat idem } \\
\text { Ne kāādirem ser-i kūyuñ varup ziyāret idem } \\
\text { Ne vüs` at oldı saña hāälümi hịikāyet idem } \\
\text { Ne furșat oldı ki hicrān gamın rivāyet idem }\end{array}$ & 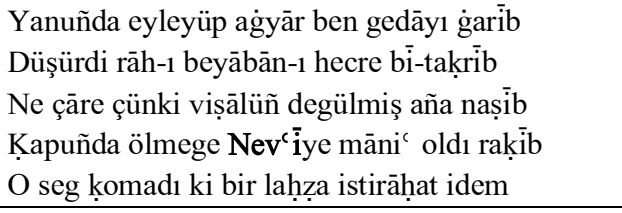 & tahmis $/ 5$ & -..-...---..-./..- & $\begin{array}{l}\text { Başlık: Tahmis-i } \\
\operatorname{Nev}^{`} \bar{i}\end{array}$ \\
\hline $78 \mathrm{a}$ & & $\begin{array}{l}\text { Lālenüñ bād-1 șabā ḳapdı külāhın didi gel } \\
\text { Kelle șaġ olsun cihānda bir külāh eksük degül }\end{array}$ & & matla'/1 & -.---/.---/-.--/-.- & Başlık: Müfred \\
\hline $78 \mathrm{a}$ & & $\begin{array}{l}\text { Himmetüñ ac lāya eyle zerre gibi çerhe çık } \\
\text { Düşüp alçaḳlarda ḳalma ḳațre-i şeb-nem gibi }\end{array}$ & & müfred/1 & -.---/.---/-.---/.-- & Başlık: Müfred \\
\hline $78 \mathrm{a}$ & & Şeref-i Ka'be büd kūy-1 tü-rā & & matla'/1 &..$--/ .-.-1 . .-$ & Başlık: Müfred \\
\hline
\end{tabular}

SEFAD, 2017 (38): 211-264 


\begin{tabular}{|c|c|c|c|c|c|c|}
\hline & & Rād-hā Allāh te' ālā şerefā & & & & \\
\hline $78 b$ & $\operatorname{Sa} \bar{a}^{\prime} \overline{\mathrm{i}}$ & $\begin{array}{l}\text { 'Ālemde șafā sebz-i ruh-1 yārı bilürsin } \\
\text { Ġam gelse saña ḥile-i aḡyārı bilürsin } \\
\text { Mā'il saña ol şūh-1 sitemkārı bilürsin } \\
\text { Kec-revlik ider çerh-i sitemkārı bilürsin } \\
\text { Ne kūyına bir furșat olup varı bilürsin } \\
\text { Ne yārı bulup ḳapuda yalvarı bilürsin }\end{array}$ & 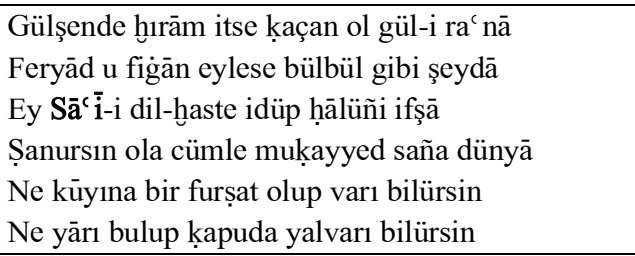 & müseddes $/ 5$ & --./.--./.---./.-- & $\begin{array}{l}\text { Başlik: Müseddes-i } \\
\operatorname{Sa}^{-} \overline{\bar{i}}\end{array}$ \\
\hline $79 a$ & & $\begin{array}{l}\text { 'Aceb ol yāra n’eylesem bilmem } \\
\text { Ol sitemkāra n'eylesem bilmem } \\
\text { Dā 'imā gül-ruh ile baḥs eyler } \\
\text { Gül-i gülzāra n'eylesem bilmem }\end{array}$ & & $\mathrm{k} 1 \mathrm{t}^{\mathrm{c}} \mathrm{a} / 1$ & ..-- /.-.- /..- & Başlık: Kit ${ }^{\mathrm{c}} \mathrm{a}^{23}$ \\
\hline $79 a$ & Fużūli & $\begin{array}{l}\text { Ol perīveş kim melāḥat mülkinüñ sultānı̀dur } \\
\text { Hükm anuñ hüükmi baña fermān anuñ fermānıdur }\end{array}$ & $\begin{array}{l}\text { Ey Fużūli ola kim raḥm ide yār efḡānuña } \\
\text { Agglag̉ıl zār anca kim zār ag̉lamaḳ imkānıdur }\end{array}$ & gazel/5 & -.--/-.---/..--/-.- & Başlık: Fużūli \\
\hline $79 b$ & Bāḳi & $\begin{array}{l}\text { Devrān ayaġın şöyle şikest itdi şarābuñ } \\
\text { Gūyā ki gözi degdi mey-i nāba ḥabābuñ }\end{array}$ & $\begin{array}{l}\text { Bākīi yine șaçıldı nemek bāde-i nāba } \\
\text { Bilsek 'acabā aṣlı nedür bu şeker-ābuñ }\end{array}$ & gazel/5 & ---./.--./.--./.-- & Başlık: Bāḳī \\
\hline $79 b$ & Huyāli & $\begin{array}{l}\text { Günümi kara iden zülf-i siyehkāruñdur } \\
\text { Beni odlara yaḳan āteş-i ruhsāruñdur }\end{array}$ & $\begin{array}{l}\text { Șu gibi yüz süriyü geldi Hayāli ḳapuña } \\
\text { An1 redd itme şehā ' āşık-1 dīdāruñdur }\end{array}$ & gazel/5 & ..-- /..-- /..-- /..- & Başlık: Ḩayāli \\
\hline $80 \mathrm{a}$ & Şuhūdī & $\begin{array}{l}\text { Sāḳi getür piyāleyi țut elde sāğarı } \\
\text { Dök āb-1 huşke luṭf ile gel āteş-i teri }\end{array}$ & $\begin{array}{l}\text { Cān gerdeninde halḳa-i zencīir zülf-i dōst } \\
\text { Olmaḳ geçer Şuhūdí żamírinde Hayderi }\end{array}$ & gazel/5 & --. /-... /.--. /-.. & Başlık: Şuhūdī \\
\hline $80 \mathrm{a}$ & Emri & $\begin{array}{l}\text { Kaşlaruñ kim ‘ ayn-1 lac l-i dür-feşān üstindedür } \\
\text { Pül durur gūyā ki bir cūy-1 revān üstindedür }\end{array}$ & $\begin{array}{l}\text { Kanlu yaşum içre Emrī bu felek beñzer hemān } \\
\text { Şol ḩabāba kim şarāb-1 ergaavān üstindedür }\end{array}$ & gazel/5 & -.--/-.---/-.--/-.- & Başlık: Emrī \\
\hline $80 \mathrm{~b}$ & Bāḳi & $\begin{array}{l}\text { Lebüñi āl ile öpmiş ola mı peymāne } \\
\text { İçeyin ölmez isem ḳanını ḳana ḳana }\end{array}$ & $\begin{array}{l}\text { 'Ayş u ' işret demidür çekme ġam-1 devrānı } \\
\text { Bāḳiyā gel berü sāgar çekelüm rindāne }\end{array}$ & gazel/5 & ..-- /..-- /..-- /..- & Başlık: Bāḳi \\
\hline $80 \mathrm{~b}$ & Fehmi $\bar{i}$ & $\begin{array}{l}\text { Riżā göster ne fermān itse dilber } \\
\text { Vefā ḳılmazsa hod cevri muḳarrer }\end{array}$ & $\begin{array}{l}\text { N'ola vuşlatda pervāz itse Fehmi } \\
\text { Hemiş̧e ' āşıḳ olan uçmaḳ ister }\end{array}$ & gazel/5 & .---/.---/.-- & Başlık: Fehmi \\
\hline $81 \mathrm{a}$ & Husrev & $\begin{array}{l}\text { Yeşiller giydügüñce țīțîi-i gūyāya beñzersin } \\
\text { Siyeh-pūş olduġuñca Ka'be-i ' ulyāya beñzersin }\end{array}$ & $\begin{array}{l}\text { O gül-ruhsārı vașf itdüñ 'aceb rengīn edālarla } \\
\text { Sözüñde Husrevā sen bülbül-i şeydāya beñzersin }\end{array}$ & gazel/5 & .---/.---/.---/.--- & Başlık: Huusrev \\
\hline $81 \mathrm{a}$ & Fużūli & $\begin{array}{l}\text { Teşne-i cām-1 vișālüñ āb-1 hayvān istemez } \\
\text { Mā'ili-i mūr-1 hațuñ mülk-i Süleymān istemez }\end{array}$ & $\begin{array}{l}\text { Ey Fużūlī muttaṣıl devrān muhālifdür saña } \\
\text { Gaālibā erbāb-1 isti` dādı vîrān istemez }\end{array}$ & gazel/5 & -.--/-.---/-.--/-.- & Başlık: Fużūuli \\
\hline $81 b$ & Ḥāletī & $\begin{array}{l}\text { Cihānda nār-1 '1ş̧ữũ düşmedük bir yir mi ḳalmışdur } \\
\text { Senüñ zulmüñnle virān olmaduk kişver mi ḳalmışdur }\end{array}$ & $\begin{array}{l}\text { Senüñ bār-1 belā dehr ḳahruñ çekmege cānā } \\
\text { Hemān 'uşşāḳ içinde Ḥāleti kemter mi ḳalmışdur }\end{array}$ & gazel/5 & |-------/.---/.--- & Başlık: Hāletī \\
\hline $81 \mathrm{~b}$ & Bāḳi & İrdüm fig̀ān u zār ile ol āşiyāna ben & Bāḳi müsellem oldı baña kişver-i suhan & gazel/5 & --./-.../.--. /-..- & Başlık: Bāḳi \\
\hline
\end{tabular}

${ }^{23}$ Yazmada başlık "Rubā̄ ī" şeklinde kayıtlıdır. 


\begin{tabular}{|c|c|c|c|c|c|c|}
\hline & & Ç1ḳdum kemend-i nāle ile āsumāna ben & Geçdüm serīr-i naẓma bugün huusrevāne ben & & & \\
\hline $82 \mathrm{a}$ & Livāyí & $\begin{array}{l}\text { Āşüfteler cefā-zedeler pür-belālaruz } \\
\text { Deyr-i cihānda bir șaneme mübtelālaruz }\end{array}$ & $\begin{array}{l}\text { Pervāz-1 āteşīnle dikdük livā-y1 āh } \\
\text { Yirde sipihr-i mülk-i ġama pādişālaruz }\end{array}$ & gazel/5 & --./-..-./.--./..- & Başlık: Livāyī \\
\hline $82 \mathrm{a}$ & Bākịi & $\begin{array}{l}\text { Nihāl-i kāametüñ hakkkāa ‘ aceb nahll-i dil-ārādur } \\
\text { Egerçi ḳaddüñ a' lā kākülüñ a' lādan a' lādur }\end{array}$ & $\begin{array}{l}\text { Kenār-1 bahr-i naẓma yine dürler dizdüñ ey Bākīi } \\
\text { Sütūr-1 defder-i şi ' rüñ meger emvāc-1 deryādur }\end{array}$ & gazel/5 & .---/.---/.---/.--- & Başlık: Bāḳī \\
\hline $82 b$ & $\operatorname{Nev}^{c} \overline{\mathrm{i}}$ & $\begin{array}{l}\text { Figār oldı tenüm tỉg }-1 \text { cefādan } \\
\text { Ḳoyup cānum beni çıḳdı aradan }\end{array}$ & $\begin{array}{l}\text { Bu şi` rüm sādedür maḥbūba beñzer } \\
\text { Libāsı Nev`iyā rengīn edādan }\end{array}$ & gazel/5 & .---/.---/.-- & Başlik: Nev' $\overline{\mathrm{i}}$ \\
\hline $82 b$ & 'Ārifīi & $\begin{array}{l}\text { Cānāne naẓar gayrı cevānāna baḳıılmaz } \\
\text { Hurş̧ỉd yanında meh-i tābāna baḳıllmaz }\end{array}$ & $\begin{array}{l}\text { Eşküñe n’ola ‘Ārifĩ gözler iremezse } \\
\text { Kim diḳḳat ile lücce-i ' ummāna baḳılmaz }\end{array}$ & gazel/5 & $\begin{array}{l}--. / .--. / .--. / .-- \\
\end{array}$ & Başlik: ' Ārifī \\
\hline $83 \mathrm{a}$ & Yaḥyā & $\begin{array}{l}\text { Yolına geldi cefālar itdügi cānānumuñ } \\
\text { Bī-vefādur sevdügi ol āfet-i devrānumuñ }\end{array}$ & $\begin{array}{l}\text { N'ola ey Yaḥyā șaḳınsam düşmen-i bed-ȟnāhdan } \\
\text { Cānumuñ cānı degül mi sevdügi cānānumuñ }\end{array}$ & gazel/5 & -.---/.---/-.---/..- & Başlık: Yahyāā \\
\hline $83 a$ & 'Ulvì & $\begin{array}{l}\text { Güli şermende iden ‘ārıż-1 gülgūnuñdur } \\
\text { Servi ḥayretde ḳoyan ḳāmet-i mevzūnuñdur }\end{array}$ & $\begin{array}{l}\text { ‘Ulvī’yi şevk-i vișālüñle n’ola şād itseñ } \\
\text { Çoḳ zamāndur ki senüñ ‘ āşıḳ-1 mahzūnuñdur }\end{array}$ & gazel/5 & ..-- /..-- /..-- /..- & Başlık: 'Ulvī \\
\hline $83 b$ & Zāāti & $\begin{array}{l}\text { Merḥabā ey būy-1 zülf-i dil-rübā } \\
\text { Kanḳ1 yiller esdi geldüñ bu yaña }\end{array}$ & $\begin{array}{l}\text { Öykünelden hāk-i pāy-1 dilbere } \\
\text { Çıḳdı Zātī gözlerümden tūtiyā }\end{array}$ & gazel/5 & -.---/.---/-.- & Başlık: Zātī \\
\hline $83 b$ & Murādī & $\begin{array}{l}\text { 'Āşıka raḥm ile cevr idici yārı severin } \\
\text { Hüsnine hulḳı muvāfıḳca nigārı severin }\end{array}$ & $\begin{array}{l}\text { Serv ḳaddin ḳocasın incine ger dildāruñ } \\
\text { Ey Murādī dime kim būs-1 kenārı severin }\end{array}$ & gazel/5 & ..-- /..-- /..-- /..- & Başlık: Sulțān Murād \\
\hline $84 a$ & Ḥayretī & $\begin{array}{l}\text { Olur melūl garīib ü çeker elem ` āş1k } \\
\text { Beni görüñ ki benem hem garīi ü hem `āş1k }\end{array}$ & $\begin{array}{l}\text { Be Hayretī şeh-i ' ālem degül mi na' re ile } \\
\text { Şu dem ki k̦aldura mey-hāanede 'alem 'āşşı }\end{array}$ & gazel/5 & .---/.---/.---/.--- & Başlık: Hayreti \\
\hline $84 a$ & Veysi $\bar{i}$ & $\begin{array}{l}\text { Naḳd-i vașlın o perí illere ikrār eyler } \\
\mathrm{Bu} \text { ' acebdür baña iḳrārını inkār eyler }\end{array}$ & $\begin{array}{l}\text { Veysiyā salțanat-1 dehri n’ider 'āşık olan } \\
\text { Bir ḳadeḥ mey kişiyi ‘āleme hüūnār eyler }\end{array}$ & gazel/5 & ..-- /..-- /...- /..- & Başlık: Veysī \\
\hline $84 b$ & Ümidi $\bar{i}$ & $\begin{array}{l}\text { Āyet-i hü̈snüñ görüp ỉmāna gelmişlerdenüz } \\
\text { Aç cemālüñ mușḥafin Kur' ān'a gelmişlerdenüz }\end{array}$ & $\begin{array}{l}\text { Bu Ümídī müstemendüñe şehā 'adl eyle kim } \\
\text { Hālümüz 'arż itmege sulțāna gelmişlerdenüz }\end{array}$ & gazel/5 & -.---/-.--/-.--/-.- & Başlık: Ümidī \\
\hline $84 b$ & Şem`i $\bar{i}$ & 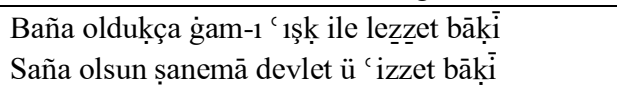 & $\begin{array}{l}\text { Şimdi bu bendeñüze luț̣uñ göster görelüm } \\
\text { Șoñra cevr eyler iseñ Şem‘ i̇ye miḥnet bāḳi }\end{array}$ & gazel/5 & ..-- /..-- /..-- /..- & Başlık: Şem` $\bar{i}$ \\
\hline $84 b$ & & $\begin{array}{l}\text { 'Āk̂lbet micmer-i pür-āteş olursun bir gün } \\
\text { Bezm-i vuṣlatda şehā saña da bir ḳor bulınur }\end{array}$ & & müfred/1 & ..-- /..-- /..-- /... & Başlık: Ferd \\
\hline $84 b$ & & $\begin{array}{l}\text { Vāḳı ‘ a ' ‘ālem-i ru’yāda o meh-ruhsārı } \\
\text { Hele bir gice çeken sinneye kim düş görmez }\end{array}$ & & müfred/1 & ..-- /..-- /..-- /..- & Başlık: Ferd \\
\hline $85 a$ & Hayretī & $\begin{array}{l}\text { Mișr-1 hüüsn içre seni sulțāna beñzetdüm hele } \\
\text { Ey 'azizüm Yūsuf-1 Ken' ān'a beñzetdüm hele }\end{array}$ & $\begin{array}{l}\text { Lebleri esrārını șordum didi ey Ḥayretī } \\
\text { Sözlerüñden ben seni ḥayrāna beñzetdüm hele }\end{array}$ & gazel/5 & -.--/-.--/-.---/.-- & Başlık: Hayreti \\
\hline $85 a$ & Hayretī & $\begin{array}{l}\text { Öpülse yār ile yār olsa dilber } \\
\text { Ḳoçılsa rām-1 dildār olsa dilber }\end{array}$ & $\begin{array}{l}\text { Cefāyı az ḳ1sa Hạretīye } \\
\text { Sözüm bu kim vefādār olsa dilber }\end{array}$ & gazel/5 & .---/.---/.-- & Başlık: Hayreti \\
\hline
\end{tabular}




\begin{tabular}{|c|c|c|c|c|c|c|}
\hline $85 b$ & Fehmi $\bar{i}$ & $\begin{array}{l}\text { Bir gün yüzüme baḳmaya ol māh ne müşkil } \\
\text { Hışm eyleye ben bendesine şāh ne müşkil }\end{array}$ & $\begin{array}{l}\text { Miḥnet iline gider iken bir kişi Fehmī } \\
\text { Gam ḳāfilesin idine hem-rāh ne müşkil }\end{array}$ & gazel/5 &.$--- / .--. / .--. / .--$ & Başlık: Fehmi \\
\hline $85 b$ & Nigāri & $\begin{array}{l}\text { Cemālüñ lālezārı böyle ḳalmaz } \\
\text { Bu gülzāruñ kenārı böyle ḳalmaz }\end{array}$ & $\begin{array}{l}\text { HUarāba yüz țutar eyvān-1 hüsnüñ } \\
\text { Anuñ naḳs u Nigārī böyle ḳalmaz }\end{array}$ & gazel/5 & .---/.---/.-- & Başlık: Nigāri \\
\hline $86 a$ & 'Ulvī & $\begin{array}{l}\text { Dirīgāa seyl-i eşküm cūy-bār olmaḳda gitdükçe } \\
\text { Benüm servüm has u hāra kenār olmaḳda gitdükçe }\end{array}$ & $\begin{array}{l}\text { Öpüp iller ayaġuñ manșı-1 a lāya irmekde } \\
\text { Dil-i ‘ Ulvī ayaḳlarda guubār olmaḳda gitdükçe }\end{array}$ & gazel/5 & & Başlık: 'Ulvī \\
\hline $86 \mathrm{a}$ & Ḥamdī & $\begin{array}{l}\text { Göñlümüz gāaret iden gamze-i fettānuñdur } \\
\text { Beni āşüfte ḳlan zülf-i perīşānuñdur }\end{array}$ & $\begin{array}{l}\text { Ruh-1 dildārı bu ān ile görüp alınduk } \\
\text { Hamdiyā çekdügümüz derd ü belā anuñdur }\end{array}$ & gazel/5 & ..-- /..-- /..-- /..- & Başlık: Ḥamdi \\
\hline $86 b$ & Cemālì & $\begin{array}{l}\text { Meclis-i meyde būse ‘ādetdür } \\
\text { Cān-1 'uşşāḳa bu sa' ādetdür }\end{array}$ & $\begin{array}{l}\text { Geçüren bādeden Cemālī seni } \\
\text { Leb-i dilberdeki halāvetdür }\end{array}$ & gazel/5 & ..-- /.-.- /..- & Başlık: Cemāli \\
\hline $86 b$ & Bāḳi & $\begin{array}{l}\text { Bulmag̀ isterdi ‘ 1şk içinde murād } \\
\text { Yār-1 Şīin degül midür Ferhād }\end{array}$ & $\begin{array}{l}\text { Bāḳī hecrüñ gamıyla cān virdi } \\
\text { Dād ey pādişāh-1 ' ālem dād }\end{array}$ & gazel/5 & ..-- /.-.- /..- & Başlık: Bāḳī \\
\hline $87 \mathrm{a}$ & Ḩayreti & $\begin{array}{l}\text { Ne āteş ü bād u ne āb u gil idüm cānā } \\
\text { Sen serv-i hevā-bahşşa ben bülbül idüm cānā }\end{array}$ & $\begin{array}{l}\text { 'Işk eyledi āvāre ben H̦ayretīyi yohssa } \\
\text { Her hidmete cān ile müsta' cil idüm cānā }\end{array}$ & gazel/5 & |--./.------./.--- & Başlık: Hayreti \\
\hline $87 \mathrm{a}$ & Yahyyā & $\begin{array}{l}\text { Bu āhum ile yaşum bu nāle vü efḡānum } \\
\text { Cānāna beyān eyler aḥvāl-i perişānum }\end{array}$ & $\begin{array}{l}\text { Yaşı gibi Yahyānuñ ḳarşuya çıḳar cānı } \\
\text { Nāz ile ḳaçan gelseñ ey āfet-i devrānum }\end{array}$ & gazel/5 & --./.---/--./.--- & Başlık: Yaḥyā \\
\hline $87 b$ & Bāḳ̄i & $\begin{array}{l}\text { Kanā' at ḳıl göñül pā-būs-1 yāre } \\
\text { Elinden būse alınmaz ne çāre }\end{array}$ & $\begin{array}{l}\text { Saña açmaz efendi Bāḳ̄ gerçi } \\
\text { Ġamuñdan gögsin itdi pāre pāre }\end{array}$ & gazel/5 & .---/.---/.-- & Başlık: Bāḳī \\
\hline $87 b$ & Beyāni & $\begin{array}{l}\text { Niçe bir āteş-i ' 1şḳ ile boyanmaḳ niçe bir } \\
\text { Niçe bir dūd-1 siyāh ile boyanmaḳ niçe bir }\end{array}$ & $\begin{array}{l}\text { Sen ferāgatda Beyāni giceler șubhạa degin } \\
\text { Ser-i kūyuñda itüñ gibi țolanmaḳ niçe bir }\end{array}$ & gazel/5 & ..-- /..-- /..-- /..- & Başlık: Beyāni \\
\hline $88 \mathrm{a}$ & Fiğāni & $\begin{array}{l}\text { Hāme-i ḳudretle yazmış nakş-bend-i Kāf u Nūn } \\
\text { Hüüsn-i hulḳ ile seni ser-defter-i mā-yenzurüūn }\end{array}$ & $\begin{array}{l}\text { Bu Fig̀āni çeşm-i ḩūn-rīz-i belā-engīzüñe } \\
\text { Eyledi teslīm-i cān innā ileyhi rāci ūin }\end{array}$ & gazel/5 & -.--/-.---/-.--/-.- & Başlık: Figānīi \\
\hline $88 \mathrm{a}$ & Behişti & $\begin{array}{l}\text { Mübtelā-yı derd ü gam bulsam melālüm söylerem } \\
\text { Ehl-i hạale rāst gelsem ḥasb-i hāalüm söylerem }\end{array}$ & 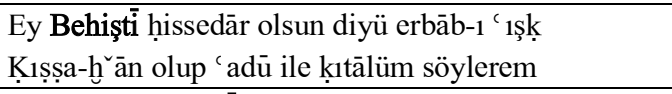 & gazel/5 & -.--/-.---/-.--/-.- & Başl1k: Behişti \\
\hline $88 b$ & Zātí & $\begin{array}{l}\text { Didüm ki benüm dilber yā Rab neme kīn eyler } \\
\text { Göñlüm didi `aynuñda olan neme kīn eyler }\end{array}$ & $\begin{array}{l}\text { Yārān didi ey Zāāi yoḳ bezm-i mahabbetde } \\
\text { Feryād u fiḡānuñdan özge nemeki n'eyler }\end{array}$ & gazel/5 & --./.---/--./.--- & Başlık: Z̄ātī \\
\hline $88 b$ & Ḥamdī & $\begin{array}{l}\text { Sīnemüñ dāġı̀n gören atar melāmet sengini } \\
\text { Gel gör ey sỉminn-beden tạg ile țaşuñ cengini }\end{array}$ & $\begin{array}{l}\text { Țaǵıddup baht-1 siyāhum Hamdiyā ol ġonçe-leb } \\
\text { Gül yüzine hāa 'il itmiş sünbül şeb-rengini }\end{array}$ & gazel/5 & -.---/.---/-.---/-.- & Başlık: Ḥamdī \\
\hline $89 a$ & Kabūlì & $\begin{array}{l}\text { Nā-dān olımaz meclis-i ‘ irfān arasında } \\
\text { Har-mühre șıgar mı dür ü mercān arasında }\end{array}$ & $\begin{array}{l}\text { Eş̧ār u gazel söyle hemān țurma Kabāuli } \\
\text { Tek añdıragör nāmuñı aḳān arasında }\end{array}$ & gazel/5 & ---./.--./.--./.-- & Başlık: Kabūli \\
\hline $89 a$ & 'Ulvī & $\begin{array}{l}\text { Şehā kūyuñda göñlüm bir gedā-yı müstemendüñdür } \\
\text { Erenler ḥaḳḳı cān u başa ḳalmaz bir levendüñür }\end{array}$ & 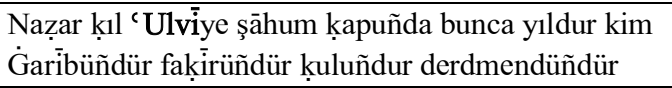 & gazel/5 & |-------/.---/.--- & Başlık: 'Ulvī \\
\hline $89 a$ & Kelāmi & İki ‘ālemde baña gösterme yā Rab & & müfred/1 & $?$ & Başlık: Kelāmī \\
\hline
\end{tabular}




\begin{tabular}{|c|c|c|c|c|c|c|}
\hline & & Çenginüñ șoyunmışını dellāküñ giyinmişini & & & & \\
\hline $89 \mathrm{a}$ & & $\begin{array}{l}\text { Niçe biñ yıl yatsa nehr içre șu geçer mi mermere } \\
\text { Güzel diyüp göñül virme delāk ile berbere }\end{array}$ & & matla'/1 & $?$ & Başlık: Ferd \\
\hline $89 b$ & Bāḳi & $\begin{array}{l}\text { Ețrāf-1 çemenzārı yine āb țolandı } \\
\text { Gülzāra girüp her yaña șalındı bulandı }\end{array}$ & $\begin{array}{l}\text { Bākỉyi mey-i nāba yemín itdi dimişler } \\
\text { Gül gibi ele sāgarar alup içmez ol andı }\end{array}$ & gazel/5 &.$-- / .--. / .---. / .--$ & Başlık: Bāḳ̄ Efendi \\
\hline $89 b$ & Bāḳi & $\begin{array}{l}\text { N'ola dehr içre nişānum yog̀ ise ' ank̦āyam } \\
\mathrm{Ne} \text { 'aceb seyl gibi çag̉lamasam deryāyam }\end{array}$ & $\begin{array}{l}\text { Bāḳiyā dīn-i Muhammed ḥaḳ1-çün `ālemde } \\
\text { Dem-i cān-bahş ile naẓm içre bu gün ‘ İ̀āyam }\end{array}$ & gazel/5 & ..-- /..-- /..-- /..- & Başlık: Bāḳ̄i Efendi \\
\hline $90 \mathrm{a}$ & Hilmi & $\begin{array}{l}\text { Ruh-1 dilberde dilā yāre diyü itme hayāl } \\
\text { Yüzi āyīnedür anda görinür ' aks-i hilāl }\end{array}$ & $\begin{array}{l}\text { Rāy-1 ruhsāredür ol yāresi yāruñ Hiilmī } \\
\text { Kalem-i șun` ile yazıldd yahod cim-i cemāl }\end{array}$ & gazel/5 & ..-- /..-- /..-- /..- & Başlık: Hilmī \\
\hline $90 \mathrm{a}$ & Husrev & $\begin{array}{l}\text { Hem-demi ḩār-1 belā hem-nefesi zār olsun } \\
\text { Tek hemān bülbül-i zāruñ yiri gülzār olsun }\end{array}$ & $\begin{array}{l}\text { Sen saña yār olıgör Husrevā ger ' āḳil iseñ } \\
\text { Yār da her kimi isterse aña yār olsun }\end{array}$ & gazel/5 &..$--/ .--/ . .--/ . .-$ & Başlık: Husrev \\
\hline $90 \mathrm{~b}$ & Bāḳi & $\begin{array}{l}\text { Țurmaz yanumda hançerini vașf ider nigār } \\
\text { Yac ni baña toḳındurur ol şūh-1 şīivekār }\end{array}$ & 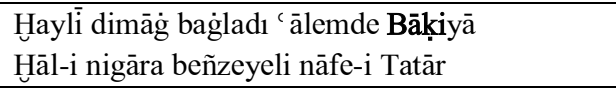 & gazel/5 & --. /-.-./.--.. /-.- & Başlık: Bāḳi Efendi \\
\hline $90 \mathrm{~b}$ & Bāḳi & $\begin{array}{l}\text { Ruhuñ berg-i gül-i sīr-āba beñzer } \\
\text { Leb-i laclüñ şarāb-1 nāba beñzer }\end{array}$ & $\begin{array}{l}\text { Cihān efsānedür aldanma Bākīi } \\
\text { Gam u şādi ḩayāl-i hñāāba beñzer }\end{array}$ & gazel/5 & .---/.---/.-- & Başlık: Bāḳ̄i Efendi \\
\hline $91 \mathrm{a}$ & İbni Kemāl & $\begin{array}{l}\text { Bir vefāsuz yār imişsin böyle bilmezdüm seni } \\
\text { Cevri çoḳ dildār imişsin böyle bilmezdüm seni }\end{array}$ & $\begin{array}{l}\text { Șu yirine kanum içse çeşm-i mahmūruñ senüñ } \\
\text { Ne ḳatı hūn-ḩāār imişsin böyle bilmezdüm seni }\end{array}$ & gazel/5 & -.---/-.--/-.--/-.- & $\begin{array}{l}\text { Başlık: Kemāl Paşa- } \\
\text { zāde }\end{array}$ \\
\hline $91 \mathrm{a}$ & Nazmi $\bar{i}$ & $\begin{array}{l}\text { 'Ahde țurmaz yār imişsin böyle bilmezdüm seni } \\
\text { Hey ne bí-iḳrār imişsin böyle bilmezdüm seni }\end{array}$ & $\begin{array}{l}\text { Būse-i lac lini cerr itdüm gülüp dilber didi } \\
\text { Nażmiyā cerrār imişsin böyle bilmezdüm seni }\end{array}$ & gazel/5 & -.--/-.---/-.--/-.- & $\begin{array}{l}\text { Başlık: Nazịire-i } \\
\text { Naẓmi }\end{array}$ \\
\hline $91 b$ & Ahmed & $\begin{array}{l}\text { Bitmedi gülşende bir gül bu ruh-1 zỉbā gibi } \\
\text { İrmedi būstānda bir serv ol ḳad-i bālā gibi }\end{array}$ & $\begin{array}{l}\text { Aḥmede şirīn lebüñden irişen düşnām-1 telh } \\
\text { Cūşlar virür șafādan telhìi-i șahbā gibi }\end{array}$ & gazel/7 & -.--/-.---/-.--/-.- & Başlık: Aḥmed Paşa \\
\hline $91 b$ & Nazmi & $\begin{array}{l}\text { 'Āşık oldur beñzi gamdan zerd ola ayvā gibi } \\
\text { Tūp ola çevgān-1 'ş̧ḳa göñli bir elmā gibi }\end{array}$ & $\begin{array}{l}\text { Ol dür-i pākízenüñ Nażmī hayālin perri dir } \\
\text { Bağrına bașsa eger şūride-dil deryā gibi }\end{array}$ & gazel/5 & -.--/-.---/.---/-.- & $\begin{array}{l}\text { Başlık: Nazịire-i } \\
\text { Naẓmi }^{24}\end{array}$ \\
\hline $92 \mathrm{a}$ & Hilāli & $\begin{array}{l}\text { Gün germ olup iñende hüsnini itmesün 'arż } \\
\text { Nisbet yüzüñle günde beyne's-semā'i ve'l-arż }\end{array}$ & $\begin{array}{l}\text { Zülf ü hațuñ șifātın yazmag içün Hilālī } \\
\text { Ter müşk ile varaḳda hoş çekdi țūl ile 'arż }\end{array}$ & gazel/5 & --./-.---/--./-.-- & Başl1k: Hilāli \\
\hline $92 \mathrm{a}$ & 'Ațā & $\begin{array}{l}\text { Her gün yüzüñe ḳarşu kendüyi ḳılmasun 'arż } \\
\text { Kim farḳ1 var senüñle beyne's-semā'i ve'l-arż }\end{array}$ & $\begin{array}{l}\text { Vaṣl-1 dehān-1 yāra sa' } y \text { it 'Ațā ḳo fikri } \\
\text { Bir dem yaḳin yigdür biñ kerre ḳılmadan farż }\end{array}$ & gazel/5 & --./-.---/--./-.-- & Başlık: Nazịire-i 'Ațā \\
\hline $92 b$ & Nazmi & $\begin{array}{l}\text { Nice ide melekler hüsnini țapuña 'arż } \\
\text { Kim anlaruñla farḳuñ beyne's-semā'i ve'l-arż }\end{array}$ & $\begin{array}{l}\text { Hecrüñde haste Nazmi hāālini n’ola ṣorsañ } \\
\text { Olmış durur 'iyādet ol cān țabibi çün farż }\end{array}$ & gazel/5 & --./-.---/--./-.-- & $\begin{array}{l}\text { Başlık: Naz̧ire-i } \\
\text { Naẓmi }\end{array}$ \\
\hline $92 b$ & Yahyā & $\begin{array}{l}\text { Kāşki göñlümdekin bildürse Allāh’um saña } \\
\text { Sen güzeller şāhınuñ göñlince olsam dā 'imā }\end{array}$ & $\begin{array}{l}\text { Șaḳın ey Yahyā șaḳın yāre vefāsuzdur dime } \\
\text { 'Āşsk itdügi büyük ihsān degül midür saña }\end{array}$ & gazel/6 & -.--/-.--/-..--/-.- & Başlık: Yahyā Beg \\
\hline $93 \mathrm{a}$ & 'Azmi & Zülfüñ ile ḳaddüñe 'ālemde her kim dirse lā & Yār işiginde raḳibi görme āsān ‘Azmiyā & gazel/5 & -.--/-.---/-.--/-..- & Başlık: Naziire-i \\
\hline
\end{tabular}

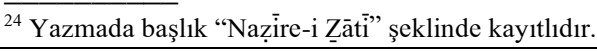

SEFAD, 2017 (38): 211-264 


\begin{tabular}{|c|c|c|c|c|c|c|}
\hline & & Lām-elif gibi nigārā ḳāmeti olsun dü-tā & 'Āşıḳa ag̉yārdan ġayrı ne var müşkil baña & & & 'Azmi \\
\hline $93 \mathrm{a}$ & Ḥüsāmi & $\begin{array}{l}\text { Hoş kemāl ile güzellik kim saña virmüş Hudā } \\
\text { Beñzemez cümle cihān dilberleri hergiz saña }\end{array}$ & $\begin{array}{l}\text { Bārí bir kez luṭfuñı görsün Ḥüsāmīi derdmend } \\
\text { Bunca yıldur işigüñnde sürinür ey bi-vefā }\end{array}$ & gazel/5 & -.--/-.---/-.--/-.- & $\begin{array}{l}\text { Başlik: Nazīire-i } \\
\text { Ḥüsāmi }\end{array}$ \\
\hline $93 \mathrm{~b}$ & Vașfī & $\begin{array}{l}\text { Benden ey dilber seni ayırmag̀ istermiş raḳīb } \\
\text { N'eyledüm ol kāfir-i bì-dīne n'itdüm ben ġarīb }\end{array}$ & $\begin{array}{l}\text { Zār u efḡān ile ger ölsem yiridür Vașfiyā } \\
\text { Kim benem ol gülşeninden ayru düşmiş ' andelīb }\end{array}$ & gazel/5 & -.--/-.---/-.--/-.- & Başl1k: Vașfīi \\
\hline $93 b$ & Ḩāveri & $\begin{array}{l}\text { Ey dil hemīşe göñlüñi alçaḳda țut çü āb } \\
\text { Șaḳın ḳabarma bād-1 gurūr ile çün ḥabāb }\end{array}$ & $\begin{array}{l}\text { Derd ocaġında Ḩāverī sen gel kömür geçin } \\
\text { Ḥırș āteşinde bağruñ ḳılma șạ̣ın kebāb }\end{array}$ & gazel/5 &.$-- /-.-. / .--. /$-..- & Başlık: Ḩāveri \\
\hline $93 b$ & Münīi & $\begin{array}{l}\text { Gün yüzine țutup nedür ol māh-rū niḳ̄āb } \\
\text { Bilür ki pertevinden anuñ hod yanar ḥicāb }\end{array}$ & $\begin{array}{l}\text { Di gamzesine gül yüzi nāzük durur Münīr } \\
\text { Pejmürde itmesün aña șlḳlet virür bu hñ̄āb }\end{array}$ & gazel/5 &.$-- /-.-. / .--. /$-.- & $\begin{array}{l}\text { Başlik: Nazïire-i } \\
\text { Münir }\end{array}$ \\
\hline $94 a$ & 'Amrí & $\begin{array}{l}\text { Dilber ki uyhuya vara gelmez gözüme ȟ̃āb } \\
\text { Öpsem țuya mı diyü çeker cānum ıżțrāb }\end{array}$ & $\begin{array}{l}\text { Peykān-1 dūst dilde karār eylemez geçer } \\
\text { 'Amrī şikeste şişede hiç eglenür mi āb }\end{array}$ & gazel/5 &.$-- /$-..-./.--./.-.- & $\begin{array}{l}\text { Başlik: Naziire-i } \\
\text { 'Amri }{ }^{25}\end{array}$ \\
\hline $94 a$ & Nașūḥi & $\begin{array}{l}\text { Gerçi pürdür hūblarla bu sarāy-1 kā 'ināt } \\
\text { Lìk yoḳdur sen melek-rū gibi bir pākíze zāa }\end{array}$ & $\begin{array}{l}\text { Baḥr-i ġam gird-ābına düşdi Nașūhīi dūstum } \\
\text { Hıżżveş irmezseñ ol ol varțadan bulmaz necāt }\end{array}$ & gazel/7 & -.--/-.---/-.--/-.-- & Başlık: Nașūhịi ${ }^{26}$ \\
\hline $94 b$ & Fehmi $\bar{i}$ & $\begin{array}{l}\text { Leblerüñ cüllāb-1 ter şīīin dehānuñdur nebāt } \\
\text { Cām-1 la' lüñ mürdeler nūş eylese bulur hayāât }\end{array}$ & $\begin{array}{l}\text { Yār ile 'ayş itmege neydi n'olaydı Fehmiyā } \\
\text { Pāy-dār olaydı ger bir pāre ` ömr-i bī-sebāt }\end{array}$ & gazel/5 & -.---/.---/-.--/-.- & $\begin{array}{l}\text { Başlık: Nažire-i } \\
\text { Fehmīi Șaruhānī }\end{array}$ \\
\hline $94 b$ & Bāḳi & $\begin{array}{l}\text { Gül yüzüñ vașfinda bülbül ḳılsa elhāānı dürüst } \\
\text { Bāg̀da bir ġonçenüñ kalmaz giríbānı dürüst }\end{array}$ & $\begin{array}{l}\text { Bākiyā fennüñde țutmaz kimse noḳsānanuñ senüñ } \\
\text { Hamdü lillāh țab` mevzūn 'aḳl mīzānı dürüst }\end{array}$ & gazel/5 & -.--/-.---/-.--/-.- & Başlık: Bāḳi Efendi \\
\hline $95 \mathrm{a}$ & Fevrí & $\begin{array}{l}\text { Hall idenler sırr-1 nażm-1 şāh-1 devrānı dürüst } \\
\text { Fehm iderler manțıụ't-ṭayr-1 Süleymān'1 dürüst }\end{array}$ & $\begin{array}{l}\text { Ben daḩı erbāb-1 divaāndan olurdum Fevriyā } \\
\text { Şāh-1 dehrüñ ben kulında olsa dīvānı dürüst }\end{array}$ & gazel/6 & -.--/-.---/-.--/-.- & Başlık: Nazịire-i Fevri \\
\hline $95 \mathrm{a}$ & Fevrí & $\begin{array}{l}\text { Rūy-1 cānāna çeken ol hatț-1 reyhāānı dürüst } \\
\text { İki gül bergine yazdı naẓm-1 Ḳur ān'ı dürüst }\end{array}$ & $\begin{array}{l}\text { İnkisār-1 dehrden Fevrī halāṣ olmaḳ ' aceb } \\
\text { Kaldı mı fahr-i cihānuñ dürr-i dendānı dürüst }\end{array}$ & gazel/5 & -.--/-.---/-.--/-.- & Başlık: Naz̧ire-i Fevri \\
\hline $95 b$ & Nazmi & $\begin{array}{l}\text { Şol siyeh hat kim țutupdur lac l-i cānānı dürüst } \\
\text { Șanki ẓulmetdür ki țutmış āb-1 ḥayvānı dürüst }\end{array}$ & $\begin{array}{l}\text { Nice kān-1 luṭf u 'ummān-1 kerem oldugìnı } \\
\text { Nazmīyem vașf itsem ol la' l-i dür-efşānı dürüst }\end{array}$ & gazel/5 & -.--/-.---/-.--/-.- & $\begin{array}{l}\text { Başlık: Nazịire-i } \\
\text { Naẓmi }\end{array}$ \\
\hline $95 b$ & Nizāāmi & $\begin{array}{l}\text { Șaçdı kāfūr üzre ' anber kākül-i müşgīn-i dūst } \\
\text { Ṭutdı cān mülkin ser-ā-ser kākül-i müşginn-i dūst }\end{array}$ & $\begin{array}{l}\text { Müntehā ḳaddinüñ üstinde Nizāāmi tọogirusı } \\
\text { Sidre țāvūsına beñzer kākül-i müşgīn-i dūst }\end{array}$ & gazel/7 & -.--/-.---/-.--/-.- & $\begin{array}{l}\text { Başlık: Nev`'i Dīger } \\
\text { Ez-ān-1 Nizāāmi }\end{array}$ \\
\hline $96 \mathrm{a}$ & Cem & $\begin{array}{l}\text { Çün eline aldı micmer kākül-i müşgīn-i dūst } \\
\text { 'Ālemi ḳıldı mu' aț̣ar kākül-i müşgīn-i dūst }\end{array}$ & $\begin{array}{l}\text { Kākülüm zencírinüñ dīvānesidür diyü Cem } \\
\text { Boynına bend urmag ister kākül-i müşgin-i dūst }\end{array}$ & gazel/7 & -.--/-.---/-.--/-.- & $\begin{array}{l}\text { Başlık: Nazīire-i } \\
\text { Sulțān Cem }\end{array}$ \\
\hline $96 \mathrm{a}$ & Hicri & $\begin{array}{l}\text { Sürüp üstüme ḩālüñ beydaḳ1 at } \\
\text { Beni manșūbe ile itdi şeh-māt }\end{array}$ & $\begin{array}{l}\text { Kuluñdur Hicrī bendeñ boynı bağlu } \\
\text { Efendi dile āzād it dile șat }\end{array}$ & gazel/5 & .---/.---/.-- & Başlık: Hicri \\
\hline $96 b$ & Nazmi & $\begin{array}{l}\text { Terk it hevā-y1 gàyrı göñül bī-nevālıg it } \\
\text { Yāruñ gedā-yı kūyı olup pādişālıg it }\end{array}$ & $\begin{array}{l}\text { Naẓm-1 güher-nisāâr ile meddāḥuñ oldı çün } \\
\text { Bīgāne olma Naẓmìye gel āşinālıg it }\end{array}$ & gazel/5 & --./-.../.--./-..- & Başlık: Naz̧mi \\
\hline
\end{tabular}

${ }^{25}$ Yazmada başlık "Nazịire-i Münīi" şeklinde kayıtlıdır.

${ }^{26}$ Yazmada başlık "Naz̧ire-i Nașūhịi" şeklinde kayıtlıdır; ancak şiir nazire değil, zemin şiirdir. 


\begin{tabular}{|c|c|c|c|c|c|c|}
\hline $96 b$ & 'Amrì & $\begin{array}{l}\text { Kāni` ol bir būse virse ḳılma cānān ile baḥs } \\
\text { Kim gedāya lāyık olmaz ehl-i iḥsān ile baḥs }\end{array}$ & $\begin{array}{l}\text { 'Amriyā tașvīir-i hüüsn itmekde mānendüñ mi var } \\
\text { Sen de bir üstādsin ḳılsañ n'ola Māni'le baḥs }\end{array}$ & gazel/7 & -.--/-.---/-.--/-..- & Başlık: 'Amrí \\
\hline $97 \mathrm{a}$ & Revānī & $\begin{array}{l}\text { Germ olup bu murg̀-1 dil ḳıldukça cānān ile baḥs } \\
\text { Gūyiyā Hüdhüd durur k'eyler Süleymān ile baḥs }\end{array}$ & $\begin{array}{l}\text { Gözlerine nükte-i la' lin Revāni añma hiç } \\
\text { Bir kişi müşkildür itmek iki fettān ile baḥs }\end{array}$ & gazel/5 & -.---/-.--/-.---/..- & $\begin{array}{l}\text { Başlik: Nazīire-i } \\
\text { Revāni }\end{array}$ \\
\hline $97 \mathrm{a}$ & Şevḳi & $\begin{array}{l}\text { N'ola dil fürḳatde gamdan itse cānān ile baḥs } \\
\text { Gicede dīvāne eyler māh-1 tābān ile baḥs }\end{array}$ & $\begin{array}{l}\text { K̦andüñ aġzı dadını virmek dilerseñ Şevkiyā } \\
\text { İt şarāb-1 lac lini șoḥbetde yārān ile baḥs }\end{array}$ & gazel/6 & -.--/-.---/-.--/-.- & Başlık: Naz̧ire-i Şevkīi \\
\hline $97 b$ & Mesihịi & $\begin{array}{l}\text { Ne hoşdur țuymadın aġyār muḥdis } \\
\text { Kulasın bezm sāḳi ola șālis }\end{array}$ & $\begin{array}{l}\text { Mesīhī ḳaldı uş bir dūst bir pūst } \\
\text { Ölicek üstühñānum ala vāris }\end{array}$ & gazel/5 & .---/.---/.-- & Başlık: Mesīhīi \\
\hline $97 b$ & İbni Kemāl & $\begin{array}{l}\text { Tāb-1 hicrānuñla çün sīnemde var sū' '-i mizāc } \\
\text { La' lüñüñ dārü'ş-şifāsindan buyur aña 'ilāc }\end{array}$ & $\begin{array}{l}\text { Başın indürmez gedā-yı ' } 1 \text { şḳ olan bașmaz ḳadem } \\
\text { Tah̆t olsa çerh-i 'āli mihr-i enver olsa tāc }\end{array}$ & gazel/5 & -.--/-.---/-.--/-.- & $\begin{array}{l}\text { Başlık: Kemāl Paşa- } \\
\text { zāde }\end{array}$ \\
\hline $98 \mathrm{a}$ & İshāāk & $\begin{array}{l}\text { Derd-i '1şkk-1 yār ile gāāyet alışmışdur mizāc } \\
\text { Eylemez hergiz țabībā şerbet ile imtizāc }\end{array}$ & $\begin{array}{l}\text { Cān metā‘ in var ise İshāāk dellāl-i ḳażā } \\
\text { Naḳde çekmek ḳașdına itmek diler āhir ḩarāc }\end{array}$ & gazel/5 & -.---/-.--/-.---/..- & $\begin{array}{l}\text { Başlık: Naẓire-i İshāạ } \\
\text { Çelebi }\end{array}$ \\
\hline $98 \mathrm{a}$ & Hilāli $\bar{i}$ & $\begin{array}{l}\text { Ḳıldı sen Yūsuf-cemāli Ḥak ser-i hūuaāna tāc } \\
\text { Yaraşur sen şāh-ı hüsne hūblardan alsa bāc }\end{array}$ & $\begin{array}{l}\text { Mihrüñi dilde Hilālī nice pinhān ide kim } \\
\text { Şem-i nūr-efşāna rūşendür ḥicāb olmaz zücāc }\end{array}$ & gazel/5 & -.--/-.---/-.--/-.- & Başlık: Naz̧ire-i Hilāli \\
\hline $98 b$ & Şem ${ }^{\prime} \bar{i}$ & $\begin{array}{l}\text { Taht-1 pirīūzi felek olursa mihr altunlu tāc } \\
\text { Var iken hāk-i derüñ itmez bu göñlüm iḥtiyāc }\end{array}$ & $\begin{array}{l}\text { Tāc-1 zerrin-i sa'ādet ister iseñ Şem'iyā } \\
\text { Țut gözüñ nergis gibi kendüñde dā 'im gözüñ aç }\end{array}$ & gazel/5 & -.--/-.---/-.--/-.- & $\begin{array}{l}\text { Başlık: Nazịire-i } \\
\text { Şem`‘ } \bar{i}\end{array}$ \\
\hline $98 \mathrm{~b}$ & Şeyhi $\bar{i}$ & $\begin{array}{l}\text { 'Işke-durur āfet-i ' aḳl u sücidür rāḥat-1 rūḥ } \\
\text { Sāḳiyā vaḳt-i șabāḥ oldı getür cām-1 șabụḥ }\end{array}$ & $\begin{array}{l}\text { Șabr-1 Eyyūb ile Şeyhī niçe bir ḳatlana dil } \\
\text { Țut ki ol hü̈sn ile Yūsuf olasın' ‘ömr ile Nūḥ }\end{array}$ & gazel/7 & ..-- /..-- /..-- /..- & Başl1k: Şeyhi \\
\hline $99 a$ & Zihni & $\begin{array}{l}\text { Dehenüñden șoraram haste dile rāḥat-1 rūḥ } \\
\text { Yoḳ dime varını vir tā ki bula rāhatı rūḥ }\end{array}$ & $\begin{array}{l}\text { 'Işḳ evin Zihnīi ne tāb ile açam dirseñ eger } \\
\text { Der-i mey-hāneden iste aña miftāḥ-1 fütūḥ }\end{array}$ & gazel/5 & ..-- /..-- /..-- /..- & Başlık: Naz̧ire-i Zihnī \\
\hline $99 \mathrm{a}$ & Vișāli & $\begin{array}{l}\text { Luțf ile lebleri cāmın șunar olursa nașūḥ } \\
\text { Nāṣıhā tevbeñi șirsın olur iseñ de Nașụh }\end{array}$ & $\begin{array}{l}\text { Vire țūfān-1 belādan bu Vișālīye necāt } \\
\text { Keşti-i șabra girerse nitekim Ḥażret-i Nūh }\end{array}$ & gazel/7 & ..-- /..-- /..-- /..- & Başlık: Naz̧ire-i Vișāli \\
\hline $99 b$ & Hāfız & $\begin{array}{l}\text { Hִamdü lillāh der-i mey-hāaneyi gördük meftūḥ } \\
\text { İçelüm cām-1 mușaffā bulalum rāḥat-1 rūḥ }\end{array}$ & $\begin{array}{l}\text { Ḥāfiza tevbeye gelsün dir iseñ ey nāṣı̣̆ } \\
\text { Ne sen ol dünyede ne tevbe vü ne nām-1 Nașūḥ }\end{array}$ & gazel/5 & ..-- /..-- /..-- /..- & $\begin{array}{l}\text { Başlık: Nazịire-i } \\
\text { Ḥâfız-1 Konevi }\end{array}$ \\
\hline $99 b$ & $\mathrm{Ca}^{\prime}$ fer & $\begin{array}{l}\text { Şafaḳdan itdi meh-i nev çü āşikār ḳadeh } \\
\text { Șun imdi bāde-i la'l lile zer-nigār ḳadeh }\end{array}$ & $\begin{array}{l}\text { Senüñle bir dem olımaya leb-be-leb } \mathrm{Ca}^{c} \text { fer } \\
\text { Ger ide hākinini devrān hezār bār ḳadeh }\end{array}$ & gazel/5 & .-.- /..-- /..-.- /..- & Başlık: $\mathrm{Ca}^{`}$ fer \\
\hline $100 \mathrm{a}$ & Sürūri & $\begin{array}{l}\text { Dilā alur eline lāle her bahār ḳadeh } \\
\text { N'ola țutarsañ eger sen de lālevār ḳadeh }\end{array}$ & $\begin{array}{l}\text { Sürūriyā çün olur her kişiye bir düşer iş } \\
\text { Șạ̣ın mey içme ider seni bī-vaḳār ḳadeh }\end{array}$ & gazel/5 & .-.- /..-- /..-.- /..- & $\begin{array}{l}\text { Başlık: Nazīire-i } \\
\text { Sürūri }\end{array}$ \\
\hline $100 \mathrm{a}$ & Zāāti & $\begin{array}{l}\text { 'Işk vaż' eyledi dilde yine bir kasasr-1 ferāh̆ } \\
\text { Olımaz aña tetimmāt sipihr-i nüh-kāh }\end{array}$ & $\begin{array}{l}\text { Derd-i Zāāî̀ye ' ilāc itme țabībā yüri var } \\
\text { 'Iş̣̣̂ bīmārı cihān içre olur mı dervāh }\end{array}$ & gazel/5 & ..-- /..-- /..-- /..- & Başlık: Z̄āti \\
\hline $100 \mathrm{~b}$ & Şem ‘ $\bar{i}$ & $\begin{array}{l}\text { Bāg̀g-1 '1şḳuñda göñül murg̀i uçup şāh-be-şāh } \\
\text { Șulu şeftāluye meyl itse olur m1 güstāh }\end{array}$ & $\begin{array}{l}\text { Nice gūş eyleye Şem`'i kişi ag̉yār sözin } \\
\text { Penbe-i gaflet ile țopțoludur kāhn-1 șımāh }\end{array}$ & gazel/5 & ..-- /..-- /..-- /..- & $\begin{array}{l}\text { Başlık: Nazịire-i } \\
\text { Şem`' } \overline{\mathrm{i}}\end{array}$ \\
\hline $100 \mathrm{~b}$ & Nazmi & Cānāne ile her ne dem içsem şarāb-1 telh & Şīinin lațīfe la' l-i lebüñ yoḳ yire sögüp & gazel/5 & --./-.-./.--./-..- & Başlık: Naẓmī \\
\hline
\end{tabular}




\begin{tabular}{|c|c|c|c|c|c|c|}
\hline & & Şīīin gelür mizāca şekerden ol āb-1 telh & Nażmìye ey şeker-dehen itmek 'ażāb-1 telh & & & \\
\hline $101 \mathrm{a}$ & Kemāl & 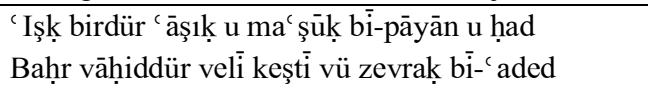 & $\begin{array}{l}\text { Gitdi Mevlānā Celāl ü geldi Mevlānā Kemāl } \\
\text { Āferin ol pīre k'andan geldi bu Sultān Veled }\end{array}$ & gazel/5 & -.--/-.---/-.--/-.- & Başlık: Kemāl-i Zerd \\
\hline $101 \mathrm{a}$ & Necātí & $\begin{array}{l}\text { Şol ḳara hālüñ zenaḩdānuñda ey hưrşīid-ḥad } \\
\text { Bir ḥabeşdür Mıșr zindānında maḥbūs-1 ebed }\end{array}$ & $\begin{array}{l}\text { Her kişi bir mesned ile irişür bir devlete } \\
\text { Pādişāhum işigüñ olsun Necātīye sened }\end{array}$ & gazel/7 & -.--/-.---/-.--/-.- & Başlık: Necāti \\
\hline $101 \mathrm{~b}$ & İbni Kemāl & $\begin{array}{l}\text { İşigüñden eşk-i çeşm-i sā 'ilin gel ḳılma red } \\
\text { Kalmış ayaḳlarda merdüm-zādedür ey serv-ḳad }\end{array}$ & $\begin{array}{l}\text { Ac1 göz yaşları ile șu virürsin dem-be-dem } \\
\text { Virmese ḳaddüñ nihāli ber n'ola ey serv-ḳad }\end{array}$ & gazel/5 & -.---/.---/-.--/-..- & $\begin{array}{l}\text { Başlık: Kemāl Paşa- } \\
\text { zāde }\end{array}$ \\
\hline $101 \mathrm{~b}$ & Șabāyī & $\begin{array}{l}\text { Ey ki naḳd-i hüüsnüñe bulmaz muhāsibler 'aded } \\
\text { İrdi alnuñla ruhuñndan mihrle māha 'aded }\end{array}$ & 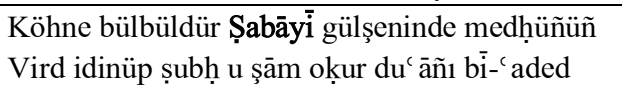 & gazel/7 & -.--/-.---/-.--/-.- & Başlık: Șabāyī \\
\hline $102 \mathrm{a}$ & Aḥmedī & $\begin{array}{l}\text { Bu ne çindür zülfüñ ucında bu ne ham bu ne bend } \\
\text { Kim anı gören azar yoldan işitmez hiç pend }\end{array}$ & $\begin{array}{l}\text { Yaydı hü̈nüñ vașfı adın Ahmedīnüñ ‘ āleme } \\
\text { Bendeñe gerçi șaçuñ sevdāsı oldı pāy-bend }\end{array}$ & gazel/7 & -.--/-.---/-.--/-.- & Başl1k: Ahmedī \\
\hline $102 \mathrm{a}$ & Zātí & $\begin{array}{l}\text { Zülfine bir şeb hațā ile didüm müşgin kemend } \\
\text { Baña ol hūb-1 Hुțāa anuñ ucından geçdi bend }\end{array}$ & $\begin{array}{l}\text { Sidre kaddin müntehā medḥ eyle ol servüñ diyü } \\
\text { Geldi hātifden baña Z̄āti bir āvāz-1 bülend }\end{array}$ & gazel/5 & -.--/-.---/-.--/-.-- & Başlık: Z̄ātī \\
\hline $102 b$ & 'İzārí & $\begin{array}{l}\text { Getürür 'ārıżı haț k'eyleye 'uşs̄ākıııı red } \\
\text { Kaçan olur ki ġubār ide hevā yolını bend }\end{array}$ & $\begin{array}{l}\text { Mesned idinmek içün geldi ‘'̇zārī ḳapuña } \\
\text { Eyleme ehl-i naẓarsın șanemā men`-i sened }\end{array}$ & gazel/5 & ..-- /..-- /..-- /..- & Başl1k: 'İżārí \\
\hline $102 \mathrm{~b}$ & Ṭālic $\overline{\mathrm{i}}$ & $\begin{array}{l}\text { Aluban göñlümi bir lāle-ruh u nesrīn-ḩad } \\
\text { Göz göre odlara yaḳdı beni zinhār meded }\end{array}$ & $\begin{array}{l}\text { Tāali ‘ } \bar{i} \text { yār işiginde niçe bir mesned arar } \\
\text { Yohsa bu seng-i melāmet aña yitmez mi sened }\end{array}$ & gazel/5 & ..-- /..-- /..-- /..- & Başlık: Ṭālic $\bar{i}$ \\
\hline $103 a$ & Mesihịi & $\begin{array}{l}\text { Beni dil-haste koyup ayrugi } 1 \text { öldürme meded } \\
\text { Ki beni andan öñürdi depeler tíg-i }-i \text { hased }\end{array}$ & $\begin{array}{l}\text { Ger mey içdiyse Mesīhīi aña ḥad lāzım olur } \\
\text { Ḳażżi lāzım degül incitmek anı fevḳa'l-ḥad }\end{array}$ & gazel/5 & ..-- /..-- /..-- /..- & Başlık: Mesihịi \\
\hline $103 a$ & Şāmi & $\begin{array}{l}\text { Ey ḳadüñ luțfuñuñ efkendesidür serv-i bülend } \\
\text { V'ey lebüñ lezzzetüñüñ hastesidür şerbet-i ḳand }\end{array}$ & $\begin{array}{l}\text { Şāmiyā şic rüñ ile buldı şeref hıtța-i Rūm } \\
\text { Nitekim şic r-i Kemāl ile şeref şehr-i Hocend }\end{array}$ & gazel/5 & ..-- /..-- /..-- /..- & Başlık: Şāmi \\
\hline $103 b$ & Vașfĩ & $\begin{array}{l}\text { Yine dil boynına zülf-i siyehüñ șaldı kemend } \\
\text { Dem mi vardur ki şehā geçmeye bend üstine bend }\end{array}$ & $\begin{array}{l}\text { Göñlüñüñ meyli levend ise şehā Vașfīye gel } \\
\text { Kanı anuñ gibi bir oñmaduk āvāre levend }\end{array}$ & gazel/5 & ..-- /..-- /...-- /..- & Başlık: Vașfĩ \\
\hline $103 b$ & $\bar{A} \bar{h} \bar{i}$ & $\begin{array}{l}\text { Güle ta` } n \text { itse ruhuñ vechi var ey serv-i bülend } \\
\text { Yaraşur lac l-i lebüñ eyler ise gonçeye hand }\end{array}$ & $\begin{array}{l}\text { Āhīnüñ irmez eli zülfüñe ey māh senüñ } \\
\text { Atar evc-i felege himmet ile gerçi kemend }\end{array}$ & gazel/5 & ..-- /..-- /..-- /..- & Başlık: Āhī \\
\hline $104 a$ & Naẓmi & $\begin{array}{l}\text { Yārı terk it diyü nāṣı̣ niçe bir göñlüme pend } \\
\text { Kimse aḳar șuyı ḥāşă k’ide hāasşāk ile bend }\end{array}$ & $\begin{array}{l}\text { Kanda teşbīh ide Nazmī leb-i la' lüñ ḳande } \\
\text { Beñzemez ey yüzi gün zeerre ḳadar la' lüñe ḳand }\end{array}$ & gazel/5 & ..-- /..-- /..-- /..- & Başlık: Naẓmí \\
\hline $104 a$ & İbni Kemāl & $\begin{array}{l}\text { Ne hoş yaraşur șafḥa-i haddüñde gümüş med } \\
\text { Şaḳu'l-ḳamer itmiş gibi engüşt-i Muḥammed }\end{array}$ & $\begin{array}{l}\text { Vaşf-1 haț u zülf olduġıçün başdan ayagaa } \\
\text { Zencir-i haț-1 şic rüme dil oldı muḳayyed }\end{array}$ & gazel/5 & --../.--./.--./.-- & $\begin{array}{l}\text { Başlık: Kemāl Paşa- } \\
\text { zāde }\end{array}$ \\
\hline $104 b$ & İbni Kemāl & 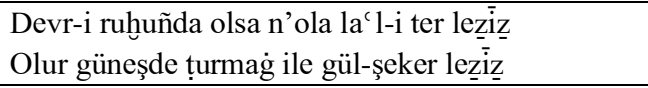 & $\begin{array}{l}\text { 'Unnāb-1 la' line çü düşe yig șafā vire } \\
\text { Turfanda irişince olur miveler leżiz }\end{array}$ & gazel/5 & --./-..-./.--./..- & $\begin{array}{l}\text { Başlık: Kemāl Paşa- } \\
\text { zāde }\end{array}$ \\
\hline $104 b$ & Şeyhī & $\begin{array}{l}\text { Ey șabā ser-menzil-i cānāna ḳılursañ güżer } \\
\text { Gülşen-i cāndur gözümden gözle rūşen ḳıl naẓar }\end{array}$ & $\begin{array}{l}\text { Şeyhīi bu āhumla yaşum göñli țaşına anuñ } \\
\text { Ol dem idiser eșer kim ḳalmaya bizden eșer }\end{array}$ & gazel/5 & -.--/-.---/-.--/-.- & Başl1k: Şeyhī \\
\hline
\end{tabular}




\begin{tabular}{|c|c|c|c|c|c|c|}
\hline $105 \mathrm{a}$ & Şāmí & $\begin{array}{l}\text { Yoluña hăc olmaġa ‘ömrüm gibi ey sim-ber } \\
\text { Eşk-i hūninümle itdüm reng-i rūyum sim ü zer }\end{array}$ & $\begin{array}{l}\text { Şāmīyem 'işkuñ yolında cān u ser terk eyledüm } \\
\text { Țañ degül 'āşı olan ger terk iderse cān u ser }\end{array}$ & gazel/5 & -.---/.---/-.--/-.- & Başlık: Şāmī \\
\hline $105 \mathrm{a}$ & Derūni & $\begin{array}{l}\text { Șaçlaruñ țarḥ it cemālüñ dehre virsün zīb ü fer } \\
\text { Kim şeb-i deycūr ile bir yirde cem` olmaz seḥer }\end{array}$ & $\begin{array}{l}\text { Ey Derūnī gül gibi feth olmasun mı vașl-1 yār } \\
\text { İştihā yalıñ ḳılıç hūn-1 vișāl mā-hazażar }\end{array}$ & gazel/5 & -.----.---/.---/-.- & Başlık: Derūni $\bar{i}$ \\
\hline $105 b$ & $\mathrm{La}^{\prime} \mathrm{li}$ & $\begin{array}{l}\text { Zāhidüñ fikrinde cennet 'āşıkuñ dīdār-1 yār } \\
\text { Her kişinüñ lācerem başında bir sevdāsı var }\end{array}$ & $\begin{array}{l}\text { Didüm ey gül var mı La‘ lī gibi bir bülbülüñ } \\
\text { Ġonçeveş ḳldı tebessüm nāz ile didi hezār }\end{array}$ & gazel/5 & -.--/-.---/-.--/-.- & Başlık: La' li \\
\hline $105 b$ & Kemāl & $\begin{array}{l}\text { Kıllalı zülfüñ kemendi göñlüm ey dildār dār } \\
\text { İderem bülbül-șıfat ben ey yüzi gülzār zār }\end{array}$ & $\begin{array}{l}\text { Teşne-dildür lac lüñe cānā Kemāl zinhār [hār] } \\
\text { Bāğ-1 hüsnüñ̃den șunagör luṭ̂ ile her bār bār }\end{array}$ & gazel/7 & -.--/-.---/-.--/-.- & Başlık: Şeyh Kemāl \\
\hline $106 a$ & Hasbi $\bar{i}$ & $\begin{array}{l}\text { Āyet-i Şems ü Żuhāa cānānenüñ ruhsārıdur } \\
\text { Sūre-i Ve'l-leyl müşgin zülfinüñ bir tārıdur }\end{array}$ & 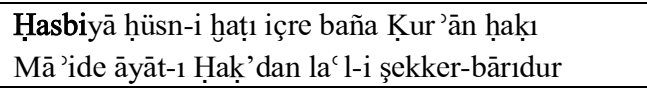 & gazel/5 & -.--/-.--/-.---/-.- & Başlık: Hasbī \\
\hline $106 a$ & Necātī & $\begin{array}{l}\text { Zülf-i miskīn kim 'ižār-1 dil-rübā üstindedür } \\
\text { Sūre-i Ve’l-leyldür kim Ve’ż-żuhāa üstindedür }\end{array}$ & $\begin{array}{l}\text { Nice ayrılsun Necāti ' '1şke-1 dilberden kim ol } \\
\text { Bir hümādur ki_àşiyān aña hevā üstindedür }\end{array}$ & gazel/7 & -.--/-.---/-.--/-.- & Başlık: Necātī \\
\hline $106 \mathrm{~b}$ & Gedāyī & $\begin{array}{l}\text { Cemālüñ nūrına hem-tā cihānda āfitāb olmaz } \\
\text { Bu rūşendür ki hurşīide mukābil māh-1 tāb olmaz }\end{array}$ & $\begin{array}{l}\text { Hुam-1 halḳa gibi oldı Gedāyi ḳaddi ḳapuñda } \\
\text { Diríg ol derdmende kim dah̆ı bir fetḥ-i bāb olmaz }\end{array}$ & gazel/7 & .---/.---/.---/.--- & Başlık: Gedāyi \\
\hline $106 \mathrm{~b}$ & Necātī & $\begin{array}{l}\text { Cihānda ādem olan bī-gam olmaz } \\
\text { Anuñçün bí-ġam olan ādem olmaz }\end{array}$ & $\begin{array}{l}\text { Necāti tevbeñi bozmak dilerler } \\
\text { Çemende lāle vü gül epsem olmaz }\end{array}$ & gazel/7 & ----/.---/.-- & Başlık: Necātī \\
\hline $107 \mathrm{a}$ & İbni Kemāl & $\begin{array}{l}\text { Bende yok gül ārzūsı itmezem serve heves } \\
\text { Dehr bāġından baña bir serv-i gül-ruhsār pes }\end{array}$ & $\begin{array}{l}\text { Eylesün bizden taḳaddüm yār işiginde rakīīb } \\
\text { Șuya ne noḳsāan gelür üstine gelse hyār u has }\end{array}$ & gazel/5 & -..--/.---/-.--/-.- & $\begin{array}{l}\text { Başlık: Kemāl Paşa- } \\
\text { zāde }\end{array}$ \\
\hline $107 \mathrm{a}$ & Necātí & $\begin{array}{l}\text { Ḩāk-i pāyuñ țūtiyā-yı dīde-i hūn-bār imiş } \\
\text { Ḥamdü lillāh kim görecek gözlerümüz var imiş }\end{array}$ & $\begin{array}{l}\text { Būseñi görmez Necātī kendüye lāyık velī } \\
\text { Ey lebi sükker ne çāre cān-durur umar imiş }\end{array}$ & gazel/5 & -.---/.---/-.--/-.- & Başl1k: Necāti \\
\hline $107 \mathrm{~b}$ & Nazmi $\bar{i}$ & $\begin{array}{l}\text { Çü yakdı dilde mihrüñ ey meh-i nā-mihribān āteş } \\
\text { N'ola dilden gelürse āh ki olmaz bì-duhān āteş }\end{array}$ & $\begin{array}{l}\text { Lebüñ yādıyla cāndan cūş ider cānā dil-i Nazmīi } \\
\text { Nitekim üstine mey dökseler eyler fiḡān āteş }\end{array}$ & gazel/5 & |---/.---/.---/.--- & Başlık: Naẓmi \\
\hline $107 \mathrm{~b}$ & Necātí & $\begin{array}{l}\text { Benüm serv-i hırāmānum cemālüñ tāze bāg̀ olmış } \\
\text { Ruhuñ güllerinüñ ḳızılı ḳızıl aġı ag olmış }\end{array}$ & $\begin{array}{l}\text { Necātī derdmend iken lebüñ dārü'ş-şifāsından } \\
\text { Maḥabbet şerbetin nūş eyleyüp fi'l-ḥāl șag olmış }\end{array}$ & gazel/5 & |---/.---/.---/.--- & Başlık: Necātī \\
\hline $108 \mathrm{a}$ & İbrāhīm & $\begin{array}{l}\text { Ayagiuñ luṭf eyle şāhum külbe-i aḥzāna baṣ } \\
\text { Gel ḳadem-rence ḳılup bu sīne-i sūzāna baș }\end{array}$ & $\begin{array}{l}\text { Aḳıdur ḳanlu yaş İbrāhīm'i gör Ya' kūūb-vār } \\
\text { Ayagiuñ luțf eyle ey Yūsuf-ḳadem Ken`ān'a baș }\end{array}$ & gazel/5 & -.--/-.---/-.--/-.. & Başl1k: İbrāhīm Paşa \\
\hline $108 \mathrm{a}$ & Aḥmed & $\begin{array}{l}\text { Hayāl-i yār ile ḳıldum bu gice șoḥbet-i hāạs } \\
\text { Semā' nālem idüpdür gözüm yaşın raḳḳāṣ }\end{array}$ & $\begin{array}{l}\text { Șimag̉a şişe-i nāmūsin Ahmed'üñ niçe bir } \\
\text { Hemişse seng-i melāmet ata 'avām u havāṣ }\end{array}$ & gazel/5 & |---/.---/.---/.--- & Başlık: Aḥmed Paşa \\
\hline $108 b$ & İbni Kemāl & $\begin{array}{l}\text { Șafha-i hüsnine șūret virdi yārüñ hāāl ü hat } \\
\text { Hatț-1 mușhaf hūūb olur ḳonduḳda i' rāb u nuḳaṭ }\end{array}$ & $\begin{array}{l}\text { 'Işk meydānında çoḳ merdāneler baş oynadı } \\
\text { Ol kemende sen giriftār olmaduñ ey dil faḳaț }\end{array}$ & gazel/6 & -.---/.---/-.--/-..- & $\begin{array}{l}\text { Başlık: Kemāl Paşa- } \\
\text { zāde }\end{array}$ \\
\hline $108 b$ & Nazmi & $\begin{array}{l}\text { Cān-fezā la' linde ol cānānenüñ kim var hat } \\
\text { Sūre-i Kevserer-durur ol hāaller anda nuḳaṭ }\end{array}$ & $\begin{array}{l}\text { Lac l-i cānān Nazmiyā yāḳūt mı yā ḳūt-1 cān } \\
\text { Sirrnñı șor bil ne cevherdür șaḳın ḳılma galaṭ }\end{array}$ & gazel/5 & -.--/-.---/-.--/-..- & Başlık: Naẓmi \\
\hline $109 a$ & Mesihịi & Ǵonçeyle çü aġzından o dilber döker elfāz & Taḳrïr-i ma`ānī-i bedī‘ eylemeyince & gazel/5 & --./.--./.--./.-- & Başlık: Mesihịi \\
\hline
\end{tabular}




\begin{tabular}{|c|c|c|c|c|c|c|}
\hline & & Dürc-i deheni içre olur șan dürer elfāẓ & Şi`r içre Mesīhī bulımaz zīb ü fer elfāẓ & & & \\
\hline $109 \mathrm{a}$ & Kemāl & $\begin{array}{l}\text { 'Ömr ise makșūduñ ey cān itmezem ḳaț ā nizā' } \\
\text { Yoluña olsun fidā bu resme olsa biñ metā'c }\end{array}$ & $\begin{array}{l}\text { 'Ālem içre yok Kemāl ehline lāyık bir șıffat } \\
\text { Ādemi yirini țutmış ser-be-ser būm u sibāc }\end{array}$ & gazel/7 & -.--/-.---/-.--/-.- & Başlık: Kemāl-i Zerd \\
\hline $109 b$ & Aḥmed & 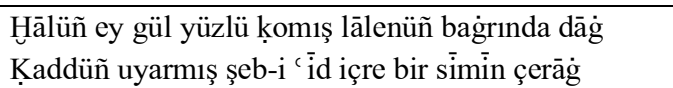 & $\begin{array}{l}\text { Ahmedi hecrüñde görüp nice bir gülsün rakīīb } \\
\text { Ancılayın bülbüle lāyılk mıdur bu cevr-i zàg }\end{array}$ & gazel/5 & -.--/-.---/-.--/-.- & Başlık: Aḥmed Paşa \\
\hline $109 b$ & Remzi & $\begin{array}{l}\text { Eyledüñ derd ehline vașluñ şarābından yasag̀ } \\
\text { Olmasun mı hey begüm bī-çāreler andan ya șag̀ }\end{array}$ & $\begin{array}{l}\text { Nār-1 gam bağrın yaḳup yandurdı göñlin Remzinüñ̃ } \\
\text { Ḥasret-i dāğ-1 siyāhuñ eyledi dāg üzre dāg }\end{array}$ & gazel/5 & -.--/-.---/-.--/-.- & Başlık: Remzì \\
\hline $110 \mathrm{a}$ & $\operatorname{Nev}^{c} \bar{i}$ & $\begin{array}{l}\text { Māye-i naḳd-i hayāàt olsa eger dīdārı } \\
\text { Ölümümdür benüm ağyār ile görmek yārı }\end{array}$ & $\begin{array}{l}\text { Ey țabīb-i dil ü cān ḳo lebüñ öpsün Nev`啇 } \\
\text { Men` iderler mi șudan hiç ölecek bīmārı }\end{array}$ & gazel/5 & ..-- /..-- /..-- /..- & Başlık: Nev' $\overline{\mathrm{i}}$ \\
\hline $110 \mathrm{a}$ & Bāḳi & $\begin{array}{l}\text { Halkk-1 'ālem gül seveydi kāşkī bülbül gibi } \\
\text { Ol lebi gonçe baña tenhā ḳalurdı gül gibi }\end{array}$ & $\begin{array}{l}\text { Çeşmüm üzre görinen hūn-ābe șanma Bākiyā } \\
\text { Gözüme geldi şarāb-1 'işḳ-1 dilber mül gibi }\end{array}$ & gazel/5 & -.--/-.---/-.--/-.- & Başlık: Bāḳī \\
\hline $110 \mathrm{~b}$ & Bāḳi & $\begin{array}{l}\text { Terk itdi ben ża ífini gitdi revān gibi } \\
\text { Gelmek müyesser olmadı bir dahı cān gibi }\end{array}$ & $\begin{array}{l}\text { Tīr-i ġamuñ nişānesidür diyü Bāk̄ììi } \\
\text { Allāh ki ḩalḳ çekdi çevürdi kemān gibi }\end{array}$ & gazel/5 & --./-.-. /.--. /-..- & Başlık: Bāḳi \\
\hline $110 \mathrm{~b}$ & Bāḳi & $\begin{array}{l}\text { Gönlin alup gonçeveş āl ile dil-teng itdiler } \\
\text { Bülbül-i şūrideye güller ` 'aceb reng itdiler }\end{array}$ & $\begin{array}{l}\text { Ruhlaruñ medḥin ser-āgāāz itdi Bāk̄ī bāġda } \\
\text { Düşdiler hep yanına bülbüller āheng itdiler }\end{array}$ & gazel/5 & -.--/-.---/-.--/-.- & Başlık: Ve lehu \\
\hline $111 \mathrm{a}$ & Naẓmi & $\begin{array}{l}\text { 'Āşŝk-1 pür-şevk șanemā kim urur ' '1şkununda lāf } \\
\text { Şem'veş başını kesseñ eylemez ḳaț' à hilāf }\end{array}$ & 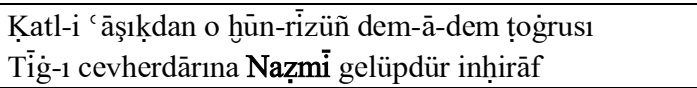 & gazel/5 & -.--/-.---/-.--/-.- & Başlık: Naẓmi \\
\hline $111 \mathrm{a}$ & Vașfĩ & $\begin{array}{l}\text { Gün yüzüñ [üzre] ne var hatț-1 siyehkār olıcak } \\
\text { Şem` rūşen olur ey māh şeb-i tār olıcak }\end{array}$ & $\begin{array}{l}\text { Raḥm ḳıl Vașfīyi öldürme giriftār görüp } \\
\text { Kāfir olmadı şehā n'ola giriftār olıcak }\end{array}$ & gazel/5 & ..-- /..-- /..-- /..- & Başlık: Vașfĩ \\
\hline $111 \mathrm{~b}$ & Naẓmi & $\begin{array}{l}\text { Seyr iden yār ile her dem n'ola ag̉yār olıcak } \\
\text { Güle nokșān ire mi hem-dem aña hār olıcak }\end{array}$ & $\begin{array}{l}\text { Ḩāțıruñ hoş mı begüm vașluñ içün Nazmininüñ } \\
\text { Naḳd-i cānı ayagiuñ tozına issār olıcak }\end{array}$ & gazel/5 & ..-- /..-- /..-- /..- & Başlık: Naẓmī \\
\hline $111 b$ & İbni Kemāl & $\begin{array}{l}\text { Açılur mı bu göñül vașl-1 nigār olmayıcaḳ } \\
\text { Ġonçe ḳaçan açılur fașl-1 bahār olmayıcak }\end{array}$ & $\begin{array}{l}\text { SSubhạa dek çeng çalar her gice ḳapuñda raḳib } \\
\text { Neyi olursa ider kişide ‘ār olmayıcaḳ }\end{array}$ & gazel/6 & ..-- /..-- /..-- /..- & $\begin{array}{l}\text { Başlık: Kemāl Paşa- } \\
\text { zāde }\end{array}$ \\
\hline $111 \mathrm{~b}$ & & $\begin{array}{l}\text { Yaşlu gözümde 'aks-i cüllāb-1 lā' l-i dilber } \\
\text { Acı deñiz içinde bir țatlu șuya beñzer }\end{array}$ & & matla'/1 & --. /-..--/--. /-.-- & Başlık: Müfred \\
\hline $112 \mathrm{a}$ & Revānī & $\begin{array}{l}\text { Lāleveş alma ele sāğarı yār olmayıcaḳ } \\
\text { Ḳılma șoḥbet hevesin tāze bahār olmayıcak }\end{array}$ & $\begin{array}{l}\text { Yār göñlümde Revānī ḳomadı șabr u karāār } \\
\text { 'Āşs1k olan nicedür șabr u ḳarār olmayıcaḳ }\end{array}$ & gazel/5 & ..-- /..-- /..-- /..- & Başlık: Revāni \\
\hline $112 \mathrm{a}$ & Nazmi & $\begin{array}{l}\text { Hevā-y1 ' 1şḳuña düşdüm benüm șabr u ḳarārum yok } \\
\text { Boyın țutdum gamuñ şemşīine andan firārum yoḳ }\end{array}$ & $\begin{array}{l}\text { Nišār içün ayağuñ tozına ey pādişāh-1 hëüsn } \\
\text { Cihānda Naz̧mìyem cān cevherinden özge varum yok }\end{array}$ & gazel/7 & .---/.---/.---/.--- & Başlık: Naẓmī \\
\hline $112 b$ & İbni Kemāl & $\begin{array}{l}\text { Ol mihr ü māh-rūyum bir serv-kāāmet ancaḳ } \\
\text { Yok yoḳ ne kāmet olsun ḳad ḳıāmet ancak }\end{array}$ & 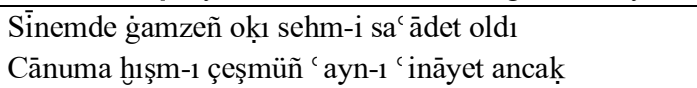 & gazel/5 & --. /-.-- /--./.-.-- & $\begin{array}{l}\text { Başlik: Kemāl Paşa- } \\
\text { zāde }\end{array}$ \\
\hline $112 b$ & Nazmí & $\begin{array}{l}\text { Hुaste-durur gamuñla dil mūnis ü gam-küsārı yoḳ } \\
\text { Derd ile nāleler ḳılur neylesün ihtiyārı yoḳ }\end{array}$ & $\begin{array}{l}\text { 'Işḳı yolında Nazmiyā zülfi gibi o dilberüñ } \\
\text { Cān ile terk-i ser ḳılup hāk olanuñ şümārı yok }\end{array}$ & gazel/5 & -.../.-../-.../.-.- & Başl1k: Naẓmi \\
\hline
\end{tabular}




\begin{tabular}{|c|c|c|c|c|c|c|}
\hline $113 a$ & Ḥıżrí & $\begin{array}{l}\text { Öykünürse yañılup gün yüzüñe māh-1 felek } \\
\text { Anuñ eksükligine billāh ḳalma ey melek }\end{array}$ & $\begin{array}{l}\text { Kaddüñi Țūbāya hūūìye seni teşbīh ider } \\
\text { Dūstum Ḥıżrì seni mi göge çıkardı_ögerek }\end{array}$ & gazel/5 & -.--/-.---/-.--/-..- & Başlık: Ḥıżri \\
\hline $113 a$ & Zātīi & $\begin{array}{l}\text { Kim bilür zülfüñ elinden yine kim oldı helāk } \\
\text { Dest-i berḳ ile bulud çekdi yaḳasın itdi çāk }\end{array}$ & $\begin{array}{l}\text { Añma adum Zāāi düşmenden hạazer ḳıl didi dūst } \\
\text { İsm-i a' ẓam oḳıyan insāna şeytānan ne bāk }\end{array}$ & gazel/5 & -.--/-.---/-.--/-.- & Başlik: Zāāi \\
\hline $113 b$ & Naẓmi & $\begin{array}{l}\text { Yolına cān virse cānā n'ola sen cānānenüñ } \\
\text { Fahridür '1ş̧ ile ölmek 'āşı̣̂-1 merdānenüñ }\end{array}$ & $\begin{array}{l}\text { Dūstum Nazmīi olaldan āşinā-yı bahr-i ' 'ışk } \\
\text { Dahı mišlin görmemişdür sen dür-i yekdānenüñ }\end{array}$ & gazel/7 & -.---/.---/-.---_.-- & Başlık: Naẓmi \\
\hline $113 b$ & Zāāti & $\begin{array}{l}\text { Kim bilür ey yüzi gülgūn yine ne āl eyledüñ } \\
\text { Ney gibi beñzüm șarardup cismümi nāl eyledüñ }\end{array}$ & $\begin{array}{l}\text { Kullaruñ ey ȟāce Zāāiden sebak alsun diyü } \\
\text { Odlara yaḳduñ beni anuñla pā-māl eyledüñ }\end{array}$ & gazel/5 & -.---/.---/-.---/..- & Başl1k: Zāāi \\
\hline $114 a$ & Nazmi & $\begin{array}{l}\text { Añdururken baña her laḥza ġam-1 hațțuñ ecel } \\
\text { Zülfüñüũn sevdāsı virür göñlüme țūl-i emel }\end{array}$ & $\begin{array}{l}\text { Hoş maḳām-1 ' işret-ābād idi bu ḳașr-1 cihān } \\
\text { İrmeseydi Nazmiyā bünyādına anuñ halel }\end{array}$ & gazel/5 & -.----.---/-.--/-.- & Başlık: Naẓmi \\
\hline $114 a$ & $\mathrm{Ca}^{\prime}$ fer & $\begin{array}{l}\text { Serv māyildugìna ḳaddüñe hācet mi delīil } \\
\text { Yoḳ hilāf aña ki el-cinsü ile'l-cinsi yemîl }\end{array}$ & $\begin{array}{l}\text { Āhirü’l-emr ser-i zülfüñi sevdā idinüp } \\
\text { Getüre Ca`fer ele bulur ise ‘ömr-i țavīl }\end{array}$ & gazel/5 & ..-- /..-- /..-- /..- & Başlık: $\mathrm{Ca}^{\prime}$ fer \\
\hline $114 \mathrm{~b}$ & Hafī & $\begin{array}{l}\text { Fitneden gerçi anuñ hāli dahı̆ hāali degül } \\
\text { Lìk cān u dil alan gözleridür ḩāli degül }\end{array}$ & $\begin{array}{l}\text { Döyemez kimse Hafĩ hūblaruñ cevrine ger } \\
\text { Kişi ‘ ālemde bularsuz dahı olmalı degül }\end{array}$ & gazel/5 & ..-- /..-- /..-- /..- & Başl1k: Hafĩ \\
\hline $114 b$ & Necātī & $\begin{array}{l}\text { Çün tevbelüsen isteme ey dil şarāb-1 āl } \\
\text { Sāḳi sözini șıma ayağı elüñe al }\end{array}$ & $\begin{array}{l}\text { Bayram irişdi her kişi beg gibi şādumān } \\
\text { Miskīin Necātī mu' tekif-i gūşe-i melāl }\end{array}$ & gazel/5 & --. /-.-../.--./-.- & Başlık: Necātī \\
\hline $115 \mathrm{a}$ & İshāāk & $\begin{array}{l}\text { Heammāma girdi nāz ile bir sīm-ten güzel } \\
\text { Leb ābdār u zülf muțarrā beden güzel }\end{array}$ & $\begin{array}{l}\text { Baḳma bahār-1 'āleme İshāḳ merd iseñ } \\
\text { Zīnetle hergiz olmaya bir pị̂re-zen güzel }\end{array}$ & gazel/7 & --.//..-./.--./-.- & Başlık: İshāạ Çelebi \\
\hline $115 \mathrm{a}$ & Gedāyī & $\begin{array}{l}\text { Hammāma girdi bir büt-i sīminn-beden güzel } \\
\text { Biñ nāz ile ṣoyındı kabādan iñen güzel }\end{array}$ & $\begin{array}{l}\text { Germiyyetin Gedāyí 'aceb görme mermerüñ } \\
\text { 'Uryān oturur üstine ol sìm-ten güzel }\end{array}$ & gazel/5 & --./-..-./.--./-.. & Başlık: Gedāyi \\
\hline $115 b$ & Șabāyī & $\begin{array}{l}\text { Ben gedā gördüm ḳapuñda luțf u ihsān u delīm } \\
\text { Yine ol deryūzeye gelmişem Allāh yā kerim }\end{array}$ & $\begin{array}{l}\text { Merhamet ḳılmaz iseñ ey dişleri dürr-i 'Aden } \\
\text { Hā Șabāyì hā bir āvāre gözi yaşlu yetīm }\end{array}$ & gazel/7 & -.--/-.---/-.--/-.-- & Başlık: Șabāȳi \\
\hline $115 b$ & Sürūri & $\begin{array}{l}\text { Seni ḳoçmaġa idi her gice țūl-i emelüm } \\
\text { Komaduñ çünki getür bāri țudaġuñ emelüm }\end{array}$ & $\begin{array}{l}\text { Öldürür hasret-i sīne bu Sürūrīini] didüm } \\
\text { Didi raḥm eyleyüben sinede an1 gömelüm }\end{array}$ & gazel/5 & ..-- /..-- /..-- /..- & $\begin{array}{l}\text { Başlı: Sürūrīi-i } \\
\text { Müderris }\end{array}$ \\
\hline $116 a$ & Rūḥi & $\begin{array}{l}\text { 'Aceb mi dūstlar bī-nūr olursa çeşm-i giryānum } \\
\text { Ki bensüz Ka' be'ye gitdi benüm ol māh-1 tābānum }\end{array}$ & $\begin{array}{l}\text { Yiridür göklere irse fig̀ān u nāleñ ey Rūhịi } \\
\text { Ki ben mūr-1 dil-efgārı koyup gitdi Süleymān'um }\end{array}$ & gazel/7 & .---/.---/.----/.--- & Başlık: Rūhīi \\
\hline $116 \mathrm{a}$ & Remzi & $\begin{array}{l}\text { N'idersin țonanup zībā gelürsin sen baña 'ömrüm } \\
\text { Güzelsin her ne kim geyseñ yaraşur key saña 'ömrüm }\end{array}$ & $\begin{array}{l}\text { Bu bāḳī ömri Remzinüñn senüñle olsun āhhir gel } \\
\text { Deni dünyā gibi olma iñende bí-beḳā ‘ ömrüm }\end{array}$ & gazel/7 & .---/.---/.---/.--- & Başl1k: Remzíi \\
\hline $116 b$ & Bāḳi & $\begin{array}{l}\text { Şeb-nem gibi șaçılsun konon eşk-i firāvānum } \\
\text { Güller gibi açılsun tek ġonçe-i ḩandānum }\end{array}$ & $\begin{array}{l}\text { Döksün güher-i eşki Bākī reh-i kūyuñda } \\
\text { Maḥșūl-i dil ü dide hep yoluña sulțānum }\end{array}$ & gazel/7 & --. /.--- /--. /.--- & Başlık: Bāḳī \\
\hline $116 b$ & Bāḳi & $\begin{array}{l}\text { 'Ālem hayayāt-1 nev bulur cānlar bag̀işlar dem-be-dem } \\
\text { Enfās-1 Rūḥu'llāhdur gūyā nesīm-i șubḥ-dem }\end{array}$ & $\begin{array}{l}\text { 'Ayş u tana" um vaḳtidür sāz u terennüm vaḳtidür } \\
\text { Bāḳi tekellüm vaḳtidür güftāre sa' y it lācerem }\end{array}$ & gazel/8 & --..-/--..-/--../--..- & Başlık: Bāḳ̄i \\
\hline $117 \mathrm{a}$ & Bāḳi & Kimseye 'sşḳuñda iẓhār itmedin meftūnlug̉um & Olmadum Bākìisṣıfat mālik metāc -1 vaṣlına & gazel/5 & -.--/-.---/-.--/-..- & Başlık: Bāḳī \\
\hline
\end{tabular}




\begin{tabular}{|c|c|c|c|c|c|c|}
\hline & & Bildiler ḥāl-i derūnum gördiler maḥzūnlug̉um & Gitdi elden naḳd-i cān āḩir görüñ mag̉būnlugium & & & \\
\hline $117 \mathrm{a}$ & Bāḳi & $\begin{array}{l}\text { Āşüfte bend-i silsile-i zülfüñe nesīm } \\
\text { Mā'il nihāl-i kāāmetüñe țab }-1 \text { müstāḳim }\end{array}$ & $\begin{array}{l}\text { Bākīiye virdi müjde-i luțfuñ hayāàt-1 nev } \\
\text { 'Ömrüñ mezīd pādişehüm yarıcuñ Kadìm }\end{array}$ & gazel/5 & --. /..../.--./...- & Başlık: Bāḳī \\
\hline $117 \mathrm{~b}$ & Bāḳ̄i & $\begin{array}{l}\text { Cānān odur ki meyl ide anı görince cān } \\
\text { Esbāb-1 hüüsni hūu ola ammā be-şarț-1 ān }\end{array}$ & $\begin{array}{l}\text { A' dāya baş egdüremez kimse Bākịiā } \\
\text { Şemşī gibi olmayıcaḳ ser-be-ser zebān }\end{array}$ & gazel/5 &.$-- /-.-. / .--. /$-.- & Başlık: Bāḳī \\
\hline $117 \mathrm{~b}$ & Bāḳi & $\begin{array}{l}\text { Çihresinde görinen șanmañ o hūnininüñ dehān } \\
\text { 'Āşıḳın kurbān iderken șıçramış bir ḳațre kan }\end{array}$ & $\begin{array}{l}\text { Gelmeye sen gül-' izāāı vașf ider bülbül-ṣıfat } \\
\text { Gülsitānı 'āleme Bākỉ gibi bir nükte-dān }\end{array}$ & gazel/5 & -.---/.---/-.--/-..- & Başlık: Bāḳi \\
\hline $118 \mathrm{a}$ & Bāḳi & $\begin{array}{l}\text { Ġam-1 hatț̣ıyla yāruñ niçe bir dil pür-melāl olsun } \\
\text { Sür ey sāḳi ayağı mur-1 gușșa pāy-māl olsun }\end{array}$ & 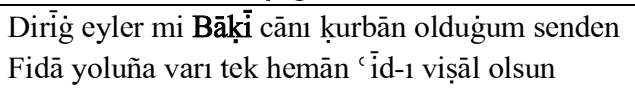 & gazel/5 & .---/.---/.---/.--- & Başlık: Bāḳi \\
\hline $118 \mathrm{a}$ & Bāḳi & $\begin{array}{l}\text { Hergiz ne kadr u cāh ne sìm ü zer isterin } \\
\text { Bir serv boylu dilber-i siminin-ber isterin }\end{array}$ & $\begin{array}{l}\text { Bāḳ̄i gedā-yı mey-gede-i ` 1şḳ olup yine } \\
\text { Bezm-i gamından ol șanemüñ sāgar isterin }\end{array}$ & gazel/7 & --. /..-./.--./..-- & Başlık: Bāḳi \\
\hline $118 b$ & Bāḳi & 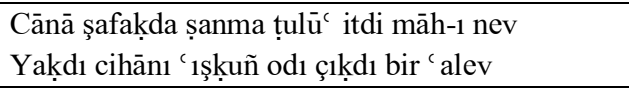 & $\begin{array}{l}\text { Bākī çek imdi cām-1 ġam-1 bezm-i fürḳatin } \\
\text { Kim didi saña yār gibi bi்-vefāyı sev }\end{array}$ & gazel/5 &.$-- /-.-. / .--. /$-.- & Başlık: Bāḳi \\
\hline $118 b$ & Ġubārí & $\begin{array}{l}\text { Nedür bu çeşm ü bu ebrū nedür bu } \\
\text { Nedür bu gamze-i cādū nedür bu }\end{array}$ & $\begin{array}{l}\text { Gubārī görmedüm hergiz nazịirin } \\
\text { Ne āfet fitne olur yā nedür bu }\end{array}$ & gazel/5 & .---/.---/.-- & Başlık: Ġubāri \\
\hline $119 a$ & $\operatorname{Nev}^{c} \overline{\mathrm{i}}$ & $\begin{array}{l}\text { Çıḳdı metā`-1 hüüsn ü melāḥat bahālara } \\
\text { Hep nāz u şīivedür șatılan mübtelālara }\end{array}$ & $\begin{array}{l}\text { Güftār-1 yār vașfinı Nev‘ } \mathbf{i} \text { gibi dahı̄ı } \\
\text { Kādir mi var zamānede hüunn ü edālara }\end{array}$ & gazel/5 & --./-..-./.--./-.- & Başlik: Nev`啇 \\
\hline $119 \mathrm{a}$ & $S \bar{a}-\bar{i}$ & $\begin{array}{l}\text { Kaldı dil hāl-i rūy-1 dilberde } \\
\text { Beni kụ itdi bir siyeh-çerde }\end{array}$ & $\begin{array}{l}\text { Hāk-i rāhuñ-durur senüñ Sāc } \bar{i} \\
\text { Pāy-māl itme anı her yirde }\end{array}$ & gazel/5 & ..-- /.-.- /..- & Başlık: $\mathrm{Sa}^{-} \overline{\mathrm{i}}^{-}$ \\
\hline $119 b$ & 'İlmi & $\begin{array}{l}\text { Gör ol hāli leb-i cānānumuzda } \\
\text { Ki niçe dāg yaḳdı cānumuzda }\end{array}$ & $\begin{array}{l}\text { 'Aceb ḥikmet nedür 'İlmī eṭ̂bbā } \\
\text { Kalur 'àciz bizüm dermānumuzda }\end{array}$ & gazel/5 & .---/.---/.-- & Başlı: ' İlmi \\
\hline $119 b$ & Emrī & $\begin{array}{l}\text { Kadeḥle meclis-i nā-dāna girme } \\
\text { Ayaguuñla varup zindāna girme }\end{array}$ & $\begin{array}{l}\text { Kabā-y1 al geyme ḳat ḳat ey gül } \\
\text { Helāk olmasun Emrí ḳana girme }\end{array}$ & gazel/5 & .---/.---/.-- & Başlık: Emrī \\
\hline $120 \mathrm{a}$ & Maḳāli & $\begin{array}{l}\text { Güzel oldur ki dilde dāg uyara } \\
\text { Er odur yaḳa bir çerāg uyara }\end{array}$ & $\begin{array}{l}\text { Bülbül-āsā Makālī nāleyi ḳo } \\
\text { Ki mebādā hezār zāg uyara }\end{array}$ & gazel/5 & ..-- /.-.- /...- & Başlık: Maḳāli \\
\hline $120 \mathrm{a}$ & ' '̇şreti & $\begin{array}{l}\text { Ger dilerseñ seni ezhār-1 ma ārif büriye } \\
\text { Bāğ-1 țabc uñda dıraht-1 gül-i raḥmet düriye }\end{array}$ & $\begin{array}{l}\text { Luțfuñı ‘'̇şreti’ye bedreḳa eyle yā Rab } \\
\text { Rāh-1 ' isyānda ḍalāletle niçe bir yüriye }\end{array}$ & gazel/5 & ..-- /..-- /..-- /..- & Başl1k: 'İşretí \\
\hline $120 \mathrm{~b}$ & 'Azizizi & $\begin{array}{l}\text { İnsāf o şehryāra cefādan ușanmaya } \\
\text { Halḳ-1 cihāna zulm ü ezādan ușanmaya }\end{array}$ & $\begin{array}{l}\text { Eyle 'Aziz̄i Hakḳa 'ibādet irince mevt } \\
\text { Bende odur ki emr-i Hudādan ușanmaya }\end{array}$ & gazel/5 & --./..-./.--./..- & Başlık: 'Azizizi \\
\hline $120 \mathrm{~b}$ & Şem ‘ $\bar{i}$ & $\begin{array}{l}\text { Ey lebi ġonçe vü beli ince } \\
\text { Baña oldı hayālüñ eglence }\end{array}$ & $\begin{array}{l}\text { Kimse tạc } n \text { eylemezdi șūfíye ger } \\
\text { Şemiyā depreneydi hālince }\end{array}$ & gazel/5 & ..-- /.-.. /...- & Başlık: Şem ‘ $\bar{i}$ \\
\hline $121 \mathrm{a}$ & 'Ulvī & $\begin{array}{l}\text { Derdümi bilmege ey dilber-i ' ayyār benüm } \\
\text { Hançer-i gamzeñle gel yüregüm yar benüm }\end{array}$ & $\begin{array}{l}\text { 'Ulviyā evc-i șadāḳatde hümā-pervāzam } \\
\text { Hem-cenāḥum olımaz Ca' fer-i Ṭayyār benüm }\end{array}$ & gazel/5 & ..-- /..-- /..-- /..- & $\begin{array}{l}\text { Başlik: El-merhūum } \\
\text { 'Ulví }\end{array}$ \\
\hline
\end{tabular}




\begin{tabular}{|c|c|c|c|c|c|c|}
\hline $121 \mathrm{a}$ & 'Ulvī & $\begin{array}{l}\text { Dilberüñon șaḳınma cānı șaḳın } \\
\text { Eyleme cānuña ziyānı șaḳın }\end{array}$ & $\begin{array}{l}\text { 'Ulviyā țutmasun cihānı şerer } \\
\text { Yaḳma āhuñla āsumānı șaḳın }\end{array}$ & gazel/7 & ..-- /.-.- /..- & $\begin{array}{l}\text { Başlık: Ve lehu } \\
\text { 'aleyhi'r-rahme }\end{array}$ \\
\hline $121 b$ & 'İşreti & $\begin{array}{l}\text { Bire gaarrā bire zībā bire beg } \\
\text { Yüzi gülden șaçı sünbülden yeg }\end{array}$ & $\begin{array}{l}\text { 'İşretī görmedi bir sencileyin } \\
\text { Mülk-i hüsne yaraşuḳ 'ādil beg }\end{array}$ & gazel/5 & ..-- /..-- /..- & Başl1k: 'İşretí \\
\hline $121 b$ & Kabūlì & $\begin{array}{l}\text { Çemen gülzāra dil lāle țuṭaḳdur } \\
\text { Gül ü nergis aña gözdür ḳulaḳdur }\end{array}$ & $\begin{array}{l}\text { Kabūlī nāżı olma şeş cihāta } \\
\text { Bilinmez dār-1 dünyā ḳaç bucaḳdur }\end{array}$ & gazel/5 & .---/.---/.-- & Başlık: Kabūli \\
\hline $122 \mathrm{a}$ & Kabūlí & $\begin{array}{l}\text { Bire āfet bire fettān-1 cihān } \\
\text { Bire zālim bire āşūb-1 zamān }\end{array}$ & $\begin{array}{l}\text { Bire bu haste Kabūlīye țabīb } \\
\text { Bire her derde 'ilāc [u] dermān }\end{array}$ & gazel/5 & ..-- /..-- /..- & Başlık: Kabūli \\
\hline $122 \mathrm{a}$ & $\operatorname{Nev}^{c} \bar{i}$ & $\begin{array}{l}\text { Kad ḳyāmetdür ' alāmetdür hațuñ } \\
\text { Müdde` à-yı hüusne ḥuccetdür ḩațuñ }\end{array}$ & 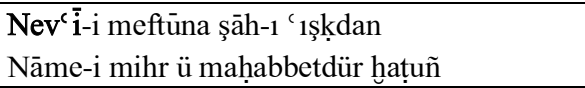 & gazel/5 & -.--/-.---/-.- & Başlık: Nev` $\overline{\mathrm{i}}$ \\
\hline $122 b$ & $S \bar{a}^{\prime} \bar{i}$ & $\begin{array}{l}\text { 'İdgāhuñ șafāsı demleridür } \\
\text { Dil-rübānuñ vefāsı demleridür }\end{array}$ & $\begin{array}{l}\text { Sarırıl ol serv-i nāza ey } \mathbf{S a ̄ c} \overline{\mathbf{i}} \\
\text { Rūm ili merḥabāsı demleridür }\end{array}$ & gazel/5 & ..-- /.-.. /..- & Başlık: Sā' $\bar{i}$ \\
\hline $122 b$ & $\mathrm{~S}_{\bar{a}}<\bar{i}$ & $\begin{array}{l}\text { Varurın kūyuña her gāh benüm sulțānum } \\
\text { Seni gördükce dirin āh benüm sulțānum }\end{array}$ & $\begin{array}{l}\text { Sā' } \overline{\mathbf{i}} \text {-i ḩaste-dilüñ nām-1 şerifüñn dilde } \\
\text { Virdidür şām u seḥergāh benüm sulțānum }\end{array}$ & gazel/5 & ..-- /..-- /..-- /..- & Başlık: Ve lehu \\
\hline $123 \mathrm{a}$ & Tecelli $^{27}$ & $\begin{array}{l}\text { Dilde her dem melāl māl-ā-māl } \\
\text { Oldum ālām ile mükedder-ḥāl }\end{array}$ & $\begin{array}{l}\text { Āh öldüm esirge gör hāälüm } \\
\text { Derdüme ol devā meded elüm al }\end{array}$ & gazel/5 & ..-- /.-.- /..- & $\begin{array}{l}\text { Başlık: Ġazel-i bī- } \\
\text { nuḳat }\end{array}$ \\
\hline $123 a$ & 'Ubeydi & $\begin{array}{l}\text { Ġama vir göñlüñi diyelden yār } \\
\text { Kendüyi virdi bu dil-i bīmār }\end{array}$ & $\begin{array}{l}\text { Husrev-i nazmsın ‘Ubeydīi saña } \\
\text { İrse Āhí olurdı sancaḳdār }\end{array}$ & gazel/5 & ..-- /.-..-/..- & $\begin{array}{l}\text { Başlık: 'Ubeydī } \\
\text { 'aleyhi'r-rahme }\end{array}$ \\
\hline $123 a$ & Sāñi & $\begin{array}{l}\text { Dilā dildāruñ ‘ālemde dil-ārā } \\
\text { Gerekdür ala vallāhi müdārā }\end{array}$ & $\begin{array}{l}\text { Ser-āmeddür o serviden ārām } \\
\text { Hevādār olsa Sַāni aña a' lā }\end{array}$ & gazel/5 & .---/.---/.-- & Başlık: SQāni \\
\hline $123 b$ & $\dot{Z} \mathrm{a}^{c} \mathrm{fi}$ & $\begin{array}{l}\text { Derd-i `'ş̧ḳa göñül devā olmaz } \\
\text { Yār cevri gibi belā olmaz }\end{array}$ & $\begin{array}{l}\text { Kim ki āyīnesini itmedi pāk } \\
\text { Ża' fiyā maẓhar-1 Hudā olmaz }\end{array}$ & gazel/5 & ..-- /.-..- /..- & Başlık: Żac fĩ \\
\hline $123 b$ & $\overline{\text { Āgehi }} \bar{i}$ & $\begin{array}{l}\text { Dilā devr itmez oldı sāgarar-1 mey } \\
\text { Biraz alçaḳ ḳodı nālişlerin ney }\end{array}$ & $\begin{array}{l}\text { Benüm ey Āgehī hāāüm mükedder } \\
\text { Mededsüz bir faḳirem hey meded hey }\end{array}$ & gazel/5 & .---/.---/.-- & Başlık: Āgehi \\
\hline $124 \mathrm{a}$ & Hayāli $\bar{i}$ & $\begin{array}{l}\text { Hayālī baḥr-i fikretde neheng-āsā şināverdür } \\
\text { Yetīm ol baḥr ḳa'rında yüzer gavvās-1 cevherdür }\end{array}$ & $\begin{array}{l}\text { Ḩayālī vādīi şic rüñ olup güm-geşte hayrānı } \\
\text { Yetīm ol vādìye düşmişlere sālār u rehberdür }\end{array}$ & gazel/5 & |----/.----------- & Başlık: Huayāli \\
\hline $124 a$ & Bāḳi & $\begin{array}{l}\text { Ṣoḥbetüñ mübtelāya șịhhat olur } \\
\text { Bir selāmuñ iren selāmet olur }\end{array}$ & $\begin{array}{l}\text { Dūstdan yek işāret ey Bākī } \\
\text { Cāna șad mūcib-i beşāret olur }\end{array}$ & gazel/5 & ..-- /.-.- /..- & Başlık: Bāḳī \\
\hline $124 b$ & Hạletī & 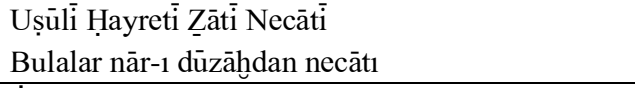 & $\begin{array}{l}\text { Faḳirī Hāletī Emrí Emīí } \\
\text { Zamānuñ şimdi anlardur emíri }\end{array}$ & gazel/5 & .---/.---/.-- & Başlık: Hāletī \\
\hline $124 b$ & 'Ā $\mathrm{A} \overline{\mathrm{i}}$ & $\begin{array}{l}\text { Ġarke-1 bahr-i gama cām-1 mey-i gülgūn olsa } \\
\text { Leb-i deryāda șafā-y1 țarab-efzūn olsa }\end{array}$ & $\begin{array}{l}\text { Niçe yüz biñ dil-i sevdā-zedem olsa 'Ālī } \\
\text { Kāşkí her biri bir āfete meftūn olsa }\end{array}$ & gazel/5 & ..-- /..-- /..-- /..- & Başlık: 'Āli \\
\hline
\end{tabular}

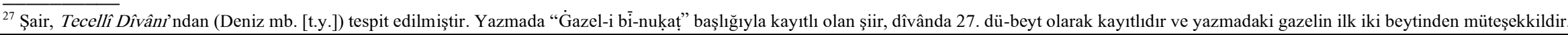
SEFAD, 2017 (38): 211-264 


\begin{tabular}{|c|c|c|c|c|c|c|}
\hline $125 \mathrm{a}$ & $\operatorname{Şem}^{c} \bar{i}$ & $\begin{array}{l}\text { Ne hūnīiür gözüñ sākēi ki bağrumdan kebāb ister } \\
\text { Döküp nā-ḥaḳ yire ḳanum kabag̉um pür-şarāb ister }\end{array}$ & $\begin{array}{l}\text { Şarāb-1 la' l-i dilberden içüp ḳanmaḳ diler göñlüm } \\
\text { Nice diviānedür Şem`‘ i görüñ āteşden āb ister }\end{array}$ & gazel/5 & .---/.---/.---/.--- & Başlik: Şem ' $\overline{\mathrm{i}}$ \\
\hline $125 \mathrm{a}$ & & $\begin{array}{l}\text { Hुalkẹ-1 ālem fehm ider şāhum senüñ miḳdāruñı } \\
\text { Sen gerekse kendüñi bende gerek dārā gözet }\end{array}$ & & müfred/1 & -.---/-.--/-.---/.-- & Başlık: Müfred \\
\hline $125 \mathrm{a}$ & & $\begin{array}{l}\text { Ag̀niyā fahr eyler ise sīm ü zerle ey faḳir } \\
\text { Eşk-i çeşm-i rūy-1 zerdüñ saña sìm ü zer yiter }\end{array}$ & & matla'/1 & -.---/-.--/-.---/-.- & Başlık: Müfred \\
\hline $125 \mathrm{a}$ & 'Ulvī & $\begin{array}{l}\text { Vefā gelmek muhāāl oldı nigār-1 dil-pesendümden } \\
\text { Ölümüm ihtiyār itdüm ușandum kendü kendümden }\end{array}$ & $\begin{array}{l}\text { Huațı geldükde didüm yāra zülfi geçdügi benden } \\
\text { Didi şükr eyle ey 'Ulvī halāạ olduñ kemendümden }\end{array}$ & gazel/5 & .---/.---/.---/.--- & Başlık: 'Ulvī \\
\hline $125 b$ & Yahyāā & $\begin{array}{l}\text { Țolaşup kākül-i ` anber-şiken-i cānāne } \\
\text { Ne k̦adar hāțtır-1 maḥzūna țoḳandı şāne }\end{array}$ & $\begin{array}{l}\text { Dil-i Yahyyāya nice șiǵsa gerek bunca ġumūm } \\
\text { Yār bilmez mi ` aceb teng idügin gam-hnāne }\end{array}$ & gazel/5 & ..-- /..-- /..-- /..- & $\begin{array}{l}\text { Başlık: Yahyā Efendi } \\
\text { sellemehullāh }\end{array}$ \\
\hline $125 b$ & & $\begin{array}{l}\text { Kāmetüñ gördi mü‘ ezzzin şaşdı kāāmetde meger } \\
\text { Kıbleden döndi imām miḥāb-1 ebrūñn görüp }\end{array}$ & & müfred/1 & ..-- /..-- /..-- /..- & Başl1k: Müfred \\
\hline $125 b$ & Yahyāā & $\begin{array}{l}\text { Dil-i şeydā n'ola meyl eylemezse vașl-1 cānāne } \\
\text { Ne zaḥmetler çeküpdür alışınca derd-i hicrāne }\end{array}$ & $\begin{array}{l}\text { Bu meclisden hemān 'uzlet-güzin olmak gerek Yahyā } \\
\text { Taḥammül eylemez 'àḳil olan evżā'c-1 mestāne }\end{array}$ & gazel/5 & .---/.---/.---/.--- & $\begin{array}{l}\text { Başlık: Yahyā Efendi } \\
\text { sellemehullāh }\end{array}$ \\
\hline $126 a$ & Bāḳ̄i & $\begin{array}{l}\text { Kūyuñ yolında niçe kez ey mihr-i bi-nazịir } \\
\text { Şeb-rev diyü dutuldı giceyle meh-i münir }\end{array}$ & 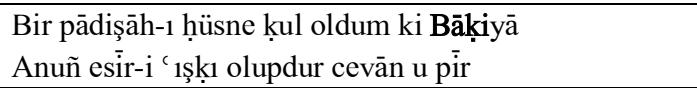 & gazel/5 & --./-..-./.--./-..- & Başl1k: Bāḳ̄i \\
\hline $126 a$ & 'Ubeydi & $\begin{array}{l}\text { Dime cānāneye ag̉yār ile șoḥbet itme } \\
\text { Seni sevsin dir iseñ aña nașịhat itme }\end{array}$ & $\begin{array}{l}\text { Çünki bunlara 'Ubeydī garażuñ var senüñ } \\
\text { Ehl-i ' arż olımadum diyü nedāmet itme }\end{array}$ & gazel/5 & ..-- /..-- /..-- /..- & Başl1k: 'Ubeydī \\
\hline $126 a$ & Mesihịi & $\begin{array}{l}\text { Kapuñda şol ḳadar ḳan ile aḳdı gözlerüm yaşı } \\
\text { Ki hep yāḳūt u la'l oldı işigüñ içi vü țaşı }\end{array}$ & $\begin{array}{l}\text { Mesīhīi bir sipāhī idi likkin pādişāh-1 '1şk } \\
\text { Ayaḳlarda görüp kıldı gözi yaşını subaş1 }\end{array}$ & gazel/5 & |---/.---/.---/.--- & Başlık: Mesīhīi \\
\hline $126 \mathrm{~b}$ & $\overline{\text { Àzādi }}$ & $\begin{array}{l}\text { Mihr-i ruhsārına öykünme șaḳın cānānuñ } \\
\text { Yüri ey māh-1 felek döndi senüñ devrānuñ }\end{array}$ & $\begin{array}{l}\text { Ġam yime simm ü zerüñ yog ise ger Āzādi } \\
\text { Ṭoludur naḳd-i sirişk ile hele dāmānuñ }\end{array}$ & gazel/5 & ..-- /..-- /..-- /..- & Başlık: Āzādi \\
\hline $126 \mathrm{~b}$ & Yahyāā & $\begin{array}{l}\text { Dilā bār-1 vișāle dest-i himmetle irilmez mi } \\
\text { Nesīm-i luṭf esmez mi o nahl-i nāz egilmez mi }\end{array}$ & $\begin{array}{l}\text { Kayurmaz seyl-i gam țaşsun gerekse başdan aşsun } \\
\text { Kümeyt-i bāde-i gülgūn ile Yahyā geçilmez mi }\end{array}$ & gazel/5 & .---/.---/.---/.--- & Başlık: Yahyyā Efendi \\
\hline $127 \mathrm{a}$ & 'İlmí & $\begin{array}{l}\text { Hudāyā gonçeveş bu kalb-i mahzūnum açılmaz m1 } \\
\text { Miyān-1 ḩārdan ol verd-i ḩandānum kesilmez mi }\end{array}$ & $\begin{array}{l}\text { Ġam-1 hecriyle yāruñ bașdı dünyāyı yem-i eşküñ } \\
\text { Senüñ seyl-i sirişküñ c '̇lmiyā yoḩsa yeñilmez mi }\end{array}$ & gazel/5 & .---/.---/.---/.--- & Başlık: 'İlmí \\
\hline $127 \mathrm{a}$ & Sipāhì & $\begin{array}{l}\text { Şive vü nāz u güzellik olıcak böyle gerek } \\
\text { Baḳa gözin süzerek söyleye sözin gülerek }\end{array}$ & $\begin{array}{l}\text { İdesin zevevk u șafā sen süresin `ālemini } \\
\text { Be Sipāhī saña bir yār olıcaḳ böyle gerek }\end{array}$ & gazel/5 & ..-- /..-- /..-- /..- & Başlık: Sipāhī \\
\hline $127 \mathrm{~b}$ & Şemsi $\bar{i}$ & $\begin{array}{l}\text { Sevdüm yine bir dilberi yā taht ola yā baht } \\
\text { Kodum yolına bu seri yā tah̆t ola yā baht }\end{array}$ & $\begin{array}{l}\text { Șidk ile kadem baṣ gelüben bu yola Şemsī } \\
\text { Yà öte ola yā beri yā taht ola yā baht }\end{array}$ & gazel/5 & --../.--./.--./.-- & Başlık: Şemsī \\
\hline $127 \mathrm{~b}$ & & $\begin{array}{l}\text { Āh efendüm baña incinmiş ' acabā ben ne günāh itdüm } \\
\text { Meger günlerde bir gün yüzine ḳarşu âh itdüm }\end{array}$ & & matla'/1 & $?$ & \\
\hline $127 \mathrm{~b}$ & Makāāi & Yār kim luṭf idüp kenāra gele & Ḥāşe lillāh ḳuluñ Makālī gibi & gazel/5 & ..-- /.-.- /..- & Başlık: Maḳāli \\
\hline
\end{tabular}




\begin{tabular}{|c|c|c|c|c|c|c|}
\hline & & Beñzer ol 'íde kim bahāra gele & Bir belā-keş bu rūzgāra gele & & & \\
\hline $128 \mathrm{a}$ & Bāḳi & $\begin{array}{l}\text { Levh-i hāțtırda hatuñ naksşını yazmaḳ 'amelüm } \\
\text { Künc-i halvetde senüñ fikr-i lebüñür emelüm }\end{array}$ & $\begin{array}{l}\text { Bāde-i mihr ü vefā sāgarırdur ey Bāḳ } \\
\text { N'ola devr eyler ise bezm-i cihānı ġazelüm }\end{array}$ & gazel/6 & ..-- /..-- /..-- /..- & Başlık: Bāḳ̄i \\
\hline $128 \mathrm{a}$ & Emri $^{-28}$ & $\begin{array}{l}\text { Seni ḳoyup dil ü cān gaayriya māyil mi olur } \\
\text { Gökde hurşide iren zerreye kāāyil mi olur }\end{array}$ & & matla'/1 &..$--/ . .--/ . .--/ . .-$ & Başlık: Müfred \\
\hline $128 \mathrm{a}$ & Bāḳi & $\begin{array}{l}\text { Eyledi müjde-i gül bülbül-i şād u hurrem } \\
\text { Ġonçenüñ göñli açıldı güle düşdi şebnem }\end{array}$ & $\begin{array}{l}\text { Āb-dār olsa n'ola mīve-i şi`r-i Bākīi } \\
\text { Urmadı kimse bu bāg içre dahı böyle ḳalem }\end{array}$ & gazel/5 &..$--/ . .--/ . .--/ . .-$ & Başlık: Bāḳ̄i \\
\hline $128 \mathrm{~b}$ & Bāḳi & $\begin{array}{l}\text { Șafā gülzārıdur sinem gül-i bī-hhārdur dāḡum } \\
\text { Maḥabbet gülşeninde açılan gülnārdur dāgum }\end{array}$ & $\begin{array}{l}\text { Kizardı göz gibi nār-1 gam-1 fürkatde ey Bāk̄ī } \\
\text { Derūnum hālin ag̉ar dīde-i hūun-bārdur dāgum }\end{array}$ & gazel/5 & .---/.---/.---/.--- & Başlık: Bāḳ̄i \\
\hline $128 \mathrm{~b}$ & Bāḳi & $\begin{array}{l}\text { Ol iki zülf-i müşg-i ġāliye-fām } \\
\text { Olmış ebrūlaruñ hilāline lām }\end{array}$ & $\begin{array}{l}\text { Kime vașf eylesem şehā seni dir } \\
\text { Bāḳiyā oldum aña ben de gulām }\end{array}$ & gazel/7 & ..-- /.-.. /..- & Başlık: Bāḳ̄i \\
\hline $129 \mathrm{a}$ & Bāḳ̄i & $\begin{array}{l}\text { Hecr-i lac lüñden dem-ā-dem göz yaşı mey-gūn olur } \\
\text { Dīde dilden dil hadeng-i gușșadan pür-hūun olur }\end{array}$ & $\begin{array}{l}\text { Gāh gāhī kūşe-i çeşmüñle ḳılmazsañ nigāh } \\
\text { Bākị-i bì-çārenüñ aḥvāli díger-gūn olur }\end{array}$ & gazel/6 & -.--/-.---/-.--/-.- & Başlık: Bāḳī \\
\hline $129 \mathrm{a}$ & & $\begin{array}{l}\text { Dūstum gerçi gören gözlerüñi șag olmaz } \\
\text { Līk naḳş-1 ruhuñu görmege țoymaġ olmaz }\end{array}$ & & matla'/1 & ..-- /..-- /..-- /..- & Başlık: Müfred \\
\hline $129 \mathrm{a}$ & Bāḳi & $\begin{array}{l}\text { Ezelden şāh-1 ' 1şḳuñ bende-i fermānıyuz cānā } \\
\text { Mahababbet mülkinüñ sulțān-1 'ālì-şānnyuz cānā }\end{array}$ & $\begin{array}{l}\text { Cihānı cām-1 naẓmum şi r r-i Bāk̄ī gibi devr eyler } \\
\text { Bu bezmüñ şimdi biz de Cāmì-i devrānıyuz cānā }\end{array}$ & gazel/5 & .---/.---/.---/.--- & Başlık: Bāḳ̄i \\
\hline $129 \mathrm{~b}$ & Bāḳi & $\begin{array}{l}\text { Cevr ü cefāña kāāyil olurdum veli şehā } \\
\text { Mahșūṣ olaydı ol da cihānda hemān baña }\end{array}$ & $\begin{array}{l}\text { Vașșāfisın o serv-kkadüñ rāstı bu kim } \\
\text { Țabc-1 bülend-țarzuña aḥsent Bāḳiyā }\end{array}$ & gazel/5 & --. /-..-./.--./..- & Başlık: Bāḳi \\
\hline $129 \mathrm{~b}$ & Bāḳi & $\begin{array}{l}\text { Hururşid kim feżā-yı felekdür mesīi aña } \\
\text { Degmez gedālar içre işigüñde yir aña }\end{array}$ & $\begin{array}{l}\text { Bākài suhanda farḳ-1 sipihre ḳadem bașar } \\
\text { Luṭ̂-1 Hुudā olursa eger dest-gír aña }\end{array}$ & gazel/5 & --. /-..-./.--./..- & Başlık: Bāḳi \\
\hline $130 \mathrm{a}$ & Bāḳi & $\begin{array}{l}\text { Gülsitān bezm-i şarāb u cām-1 mey güldür baña } \\
\text { Kulkụul-i ḥalḳ-1 șurāḥi șavt-1 bülbüldür baña }\end{array}$ & $\begin{array}{l}\text { Hayder-i Kerrār'1yam meydān-1 nazmuñ Bākiyā } \\
\text { Nevk-i hāme Züü'l-feḳār tab` Düldül'dür baña }\end{array}$ & gazel/5 & -.---/.---/-.---/.-- & Başlık: Bāḳi \\
\hline $130 \mathrm{a}$ & Bāḳi & $\begin{array}{l}\text { Eylesün vașlını dermān dil-i bīmāra meded } \\
\text { Dūstlar işte ben öldüm baña bir çāre meded }\end{array}$ & $\begin{array}{l}\text { Mededüñ kalmadı feryād u fìgāan eylemege } \\
\text { Saña kimden ire ey Bāḳíi-i bì-çāre meded }\end{array}$ & gazel/5 & ..-- /..-- /..-- /..- & Başlık: Bāḳ̄i \\
\hline $130 \mathrm{~b}$ & Bāḳi & $\begin{array}{l}\text { İtdi şikār göñlümi bir şūḩ u şeh-levend } \\
\text { Müjgānı tỉ̆ ü ḳaşı kemān țurrası kemend }\end{array}$ & $\begin{array}{l}\text { A` dā yanuñda huurrem u handān u şāàmān } \\
\text { Bāḳi yanuñda zār u dil-efgār u müstmend }\end{array}$ & gazel/5 & --./-..-./.--./-.- & Başlık: Bāḳi Efendi \\
\hline $130 \mathrm{~b}$ & Bāḳi & $\begin{array}{l}\text { Yārdan cevr ü cefā luṭf u kerem gibi gelür } \\
\text { Gayridan mihr ü vefā derd ü elem gibi gelür }\end{array}$ & $\begin{array}{l}\text { Bāḳiyā ḳanġı göñül şehrine gelse şeh-i ' } 1 \text { şk } \\
\text { Bile endūh u belā hayl u haşem gibi gelür }\end{array}$ & gazel/5 & ..-- /..-- /..-- /..- & Başlık: Bāḳi Efendi \\
\hline $131 \mathrm{a}$ & Behişti & $\begin{array}{l}\text { Kaçan yanumca șalınsa o kāāmeti bālā } \\
\text { Benüm ne Sidre görinür gözüme ne Ṭūbā }\end{array}$ & $\begin{array}{l}\text { Behişti bendeñi öldür efendi tỉguñ ile } \\
\text { Eger ḥasedden ölürse ' adū cehennem-rā }\end{array}$ & gazel/5 &..$--/ . .--/ . .--/ . .-$ & $\begin{array}{l}\text { Başlık: Behiştīi el- } \\
\text { vā'iz }\end{array}$ \\
\hline $131 \mathrm{a}$ & 'Āli & Șalın çep-rāst zerrin tügmelerle ey perī-sīmā & Dönüpdür necm-i gisū-dāra her bir sațrı ey ‘ Ālī & gazel/5 & .---/.---/.---/.--- & Başlık: ' $\mathrm{A} l \bar{i}$ Efendi \\
\hline
\end{tabular}

${ }^{28}$ Şair, Emrî Dîvânı'ndan (Saraç [t.y.]: 81) tespit edilmiştir. Yazmada "Müfred” başlığıyla kayıtlı olan şiir, dîvândaki 138 numaralı gazelin ilk beytidir. SEFAD, 2017 (38): 211-264 


\begin{tabular}{|c|c|c|c|c|c|c|}
\hline & & Meleksin nūrdan bāl aç da pervāz eyle bī-pervā & Bu şi` ri görse taḥsīn ide gökde kevkeb-i Şi` rā & & & \\
\hline $131 b$ & 'Āli & $\begin{array}{l}\text { Al cāmeyle o meh-pāre ḳaçan kim șalınur } \\
\text { Țutuşur hyalḳ-1 cihān şehre bir āteş șalınur }\end{array}$ & 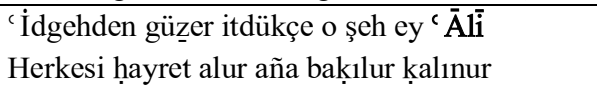 & gazel/5 & ..-- /..-- /..-- /..- & Başlık: ' $\mathrm{A} l \bar{i}$ \\
\hline $131 \mathrm{~b}$ & $\operatorname{Nev}^{c} \overline{\mathrm{i}}$ & $\begin{array}{l}\text { Ġayret-i 'ar'ar u tūbāsın sen } \\
\text { Fitne-i ' ālem-i bālāsın sen }\end{array}$ & $\begin{array}{l}\text { 'Ayb-cūlar keder isnād idemez } \\
\text { Nev' iyā baḥr-i mușaffāsın sen }\end{array}$ & gazel/5 & ..-- /..-- /..- & Başlik: Nev` $\bar{i}$ \\
\hline $132 \mathrm{a}$ & 'Ulvī & $\begin{array}{l}\text { Hançerüñ ḳıydı cāna begcegizüm } \\
\text { Hey meded girme ḳana begcegizüm }\end{array}$ & $\begin{array}{l}\text { 'Ulvi ḳuluñ gamuñdan ayrılmaz } \\
\text { Nazarar it ḥakḳ-1 nāna begcegizüm }\end{array}$ & gazel/5 & ..-- /.-.. /..- & Başl1k: 'Ulvī \\
\hline $132 \mathrm{a}$ & 'Ulvì & $\begin{array}{l}\text { Benem ol şāha mübtelā olmış } \\
\text { Āsitānında bir gedā olmış }\end{array}$ & $\begin{array}{l}\text { Ebruvānı gamıyla cānānuñ } \\
\text { 'Ulvī'nüñ kāmeti dü-tā olmış }\end{array}$ & gazel/5 & ..-- /.-.. /...- & Başlik: Ve lehu \\
\hline $132 b$ & Behişti $\bar{i}$ & $\begin{array}{l}\text { Sūz ü sāzı yiter nihān eyle } \\
\text { Vaḳtidür kendüñi ' ayān eyle } \\
\text { Meclis ehlini şādmān eyle } \\
\text { Koma bülbül ḳoma fiḡān eyle } \\
\text { 'Işḳ̂ 'ālemde dāstān eyle }\end{array}$ & $\begin{array}{l}\text { Ġam-1 ' 1şk itdügince cānuña kār } \\
\text { Niçe bir künc-i gamamda șabr u ḳaāār } \\
\text { Bu du' āyı Behişti ḳıl tekrār } \\
\text { Yā İlāhī beni de bülbül-vār } \\
\text { 'Amrí'yem zār u nā-tüvān eyle }\end{array}$ & tahmis $/ 5$ & ..-- /.-.- /...- & $\begin{array}{l}\text { Başlık: Ġazel-i 'Amrí } \\
\text { Tahmmis-i Behiştí }\end{array}$ \\
\hline $133 \mathrm{a}$ & & $\begin{array}{l}\text { Bi-ḥamdillāh cemāl-i bā-kemālüñ } \\
\text { Sa'ādetle yine tekrār gördük } \\
\text { Baḳınca ruhlaruñ āyīnesine } \\
\text { Șafā kesb eyledük dīiār gördük }\end{array}$ & & $\mathrm{k} 1 \mathrm{t}^{\mathrm{c}} \mathrm{a} / 1$ & .---/.---/.-- & Başlık: Kiț ${ }^{c} a$ \\
\hline $133 a$ & & $\begin{array}{l}\text { Dil buldı serā-perde-i dildārına vuṣlat } \\
\text { El virdi aña anda o sulțān-1 melāḥat }\end{array}$ & & matla'/1 & --./.--./.--./.-- & Başlık: Pādişāhuñdur \\
\hline $133 \mathrm{a}$ & Bāḳi & $\begin{array}{l}\text { Pür olup devr idicek meclis-i rindānı ḳadeh } \\
\text { Çerh olur halḳa-i rindān meh-i tābānı ḳadeh }\end{array}$ & 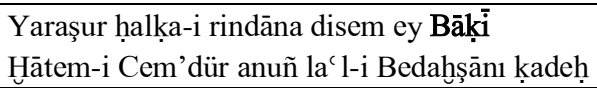 & gazel/5 & ..-- /..-- /...-- /..- & Başlık: Bāḳī \\
\hline $133 b$ & 'Ulvi & $\begin{array}{l}\text { Dilber-i şivekār böyle gerek } \\
\text { Āfet-i gamzekār böyle gerek }\end{array}$ & $\begin{array}{l}\text { Nakşınuñ oldı halk hạayrānı } \\
\text { 'Ulvī naksss-1 nigār böyle gerek }\end{array}$ & gazel/5 & ..-- /.-.- /..- & Başlık: 'Ulvī \\
\hline $133 b$ & Derūni & $\begin{array}{l}\text { Her ḥużūruñ meşakkatati biledür } \\
\text { Her șafānuñ küdūreti biledür }\end{array}$ & $\begin{array}{l}\text { Ey Derūnī mariżż' ‘ 1şk olanuñ } \\
\text { Kāse-i serde şerbeti biledür }\end{array}$ & gazel/5 &..$--/ .-.-/ . .-$ & Başlık: Derūnī \\
\hline $134 b$ & Zātín ${ }^{29}$ & $\begin{array}{l}\text { Şīşe-i hecr olsa yirüm n'ola mānend-i gül-āb } \\
\text { A felek bir tāze ter gülden çıkarduñ sen beni }\end{array}$ & & müfred/1 & -.----.---/.---/-.- & Başl1k: Müfred \\
\hline $134 b$ & & $\begin{array}{l}\text { N'ola mānenddür bağrum diline ġușșa vü ġamdan } \\
\text { Beni ey çerh bir bahr-i melāḥatden ayırduñ sen }\end{array}$ & & müfred/1 & .---/.---/.---/.--- & Başlık: Müfred \\
\hline
\end{tabular}




\begin{tabular}{|c|c|c|c|c|c|c|}
\hline $134 \mathrm{~b}$ & Bāki $\dot{i}^{30}$ & $\begin{array}{l}\text { Görmez mis̄āl-i ḳāmetüñi çeşm-i rāst-bīn } \\
\text { Aḥvel baḳa meger ki görenler naẓir aña }\end{array}$ & & müfred/1 & --. /-..-./.--./-.- & Başlık: Müfred \\
\hline $134 \mathrm{~b}$ & & $\begin{array}{l}\text { Baḳdukça olur dīdelerüm } . .^{31} \text { aḥvel } \\
\text { Bir dilberi görmek ne belādur pederiyle }\end{array}$ & & müfred/1 & --../.--./.--./.-- & Başlık: Müfred \\
\hline $134 b$ & & $\begin{array}{l}\text { Üftāde-i çeh-i zeḳanum yok halāșa rāh } \\
\text { Mihr olmayınca tār-1 hațuñdan baña resen }\end{array}$ & & müfred/1 & --. /-.../.--.//.-- & Başlık: Müfred \\
\hline $134 b$ & & $\begin{array}{l}\text { Fülk-i dil girdāb-1 ' 1şḳa șanma kim bulur kenār } \\
\text { Hatț-1 hūb tā ki görine baḥr-i hüunüñ ḳarası }\end{array}$ & & müfred /1 & -.---/.---/-.--/-.- & Başlık: Müfred \\
\hline $134 \mathrm{~b}$ & & $\begin{array}{l}\text { Olmış gurāb hatț-1 ‘izārında cilve-ger } \\
\text { Varsun tökince çınar görsün rakịib har }\end{array}$ & & matla'/1 & --../-.../.--. /-..- & Başlık: Müfred \\
\hline $134 \mathrm{~b}$ & & $\begin{array}{l}\text { Vücūdum zevraḳın bād-1 fenāya virdi bir āfet } \\
\text { Varup baḥr-i belāda fülk bir yāre çarpıldı }\end{array}$ & & müfred /1 & .---/.---/.----/.--- & Başlık: Müfred \\
\hline $134 b$ & & $\begin{array}{l}\text { Beden keştī resen cān pīrehen yelken göñül deryā } \\
\text { Sütūnı dūd-1 āhumdur muvāfık rūzgār ister }\end{array}$ & & müfred /1 & .---/.---/.---/.--- & Başlık: Müfred \\
\hline $134 b$ & & $\begin{array}{l}\text { 'Ayn-1 hā kibrüñ elif üste müdābir durur } \\
\text { Āh ezelden ser-i sūd aduma yazdurur }\end{array}$ & & matla'/1 & $?$ & Başlık: Müfred \\
\hline $134 b$ & & $\begin{array}{l}\text { Bir nìm-nigeh-i luṭf ile vac deye ma' hūd idi ammā } \\
\text { Yine pā-sitādla rücū' eyledi Levend-zāde }\end{array}$ & & müfred /1 & $?$ & Başl1k: Müfred \\
\hline $134 \mathrm{~b}$ & & $\begin{array}{l}\text { Bir gulām-1 mūy-tāb ile iderken ḳil ü ḳāl } \\
\text { Duydı pā-bend oldıġın șan`atla ḳardı kūsdan }\end{array}$ & & müfred /1 & -.---/.---/-..--/..- & Başlık: Müfred \\
\hline $134 b$ & & $\begin{array}{l}\text { Çemende șanmañuz oldı şüküfeler tezyin } \\
\text { Ġamuñla ḩaste yaturken çiçek çıkardı zemin }\end{array}$ & & matla'/1 & ..-./..---...-./..- & Başlık: Müfred \\
\hline $134 \mathrm{~b}$ & Emri $^{\overline{3}}$ & $\begin{array}{l}\text { Yār çāh-1 zeḳanum ‘ayn-1 vefādur dir ise } \\
\text { Șaḳın ey 'āşı̣̂-1 bì-çāre inanma çeñedür }\end{array}$ & & müfred /1 & ..-- /..-- /..-- /..- & Başlık: Müfred \\
\hline $134 b$ & & $\begin{array}{l}\text { Haste olmış rakiib-i gür şer diler } \\
\text { Meded eyleñ yitişdürüñ giyehe }\end{array}$ & & müfred / 1 & ..-- /.-.- /..- & Başlık: Müfred \\
\hline $135 \mathrm{a}$ & Ḥāfiz & $\begin{array}{l}\text { Aldı ețrāfi ' adū imdāda 'asker yok mıdur } \\
\text { Dīn yolında baş virür merdāne bir er yoḳ mıdur }\end{array}$ & $\begin{array}{l}\text { Dergeh-i ‘ālem-i medāra nāmemüz irsāline } \\
\text { Bād-1 șarșar gibi Hāāfı̣ bir kebūter yoḳ mıdur }\end{array}$ & gazel/7 & -.---/.---/-.--/-.-- & $\begin{array}{l}\text { Başlık: Hāāız Paşa } \\
\text { Güft }\end{array}$ \\
\hline $135 \mathrm{a}$ & Şemsi $\bar{i}$ & $\begin{array}{l}\text { Aldı ețrāfi ' adū imdāda 'asker ḳalmadı } \\
\text { Dīn yolında baş virür merdāne bir er ḳalmadı }\end{array}$ & $\begin{array}{l}\text { Pādişāha nāmeñüz î̀āāline Hāāiz sizüñ } \\
\text { Bād-1 șarșarına hāāi bir kebūter ḳalmadı }\end{array}$ & gazel/7 & -.---/.---/-.--/-.-- & $\begin{array}{l}\text { Başl1k: Nazịire-i } \\
\text { Şemsi Çelebi }\end{array}$ \\
\hline
\end{tabular}

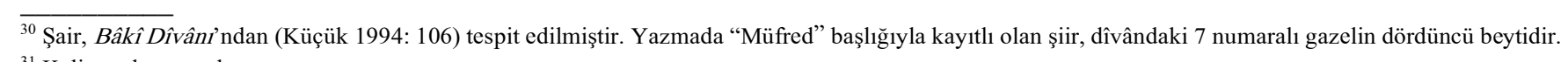

${ }^{31}$ Kelime okunamadi.

${ }^{32}$ Şair, Emrî Dîvânı'ndan (Saraç [t.y.]: 333) tespit edilmiştir.

SEFAD, 2017 (38): 211-264 


\begin{tabular}{|c|c|c|c|c|c|c|}
\hline $135 b$ & Ṭālic $\bar{i}$ & $\begin{array}{l}\text { Mestāne kūy-1 yāra düşerse güzārumuz } \\
\text { Seyl-i sirişkle gide cism-i nizārumuz }\end{array}$ & $\begin{array}{l}\text { Hecriyle Țālic } \overline{\mathbf{i}} \text { düşeli deşt-i miḥnete } \\
\text { Gușșa nedīm-durur dile gam oldı yārumuz }\end{array}$ & gazel/10 & --. /-... /.--. /-.- & $\begin{array}{l}\text { Başlik: Ag̀a-zāde } \\
\text { Țālic } \bar{i} \text { Çelebi }\end{array}$ \\
\hline $136 \mathrm{a}$ & & $\begin{array}{l}\text { O hüüsn-i hatț ile yākūūt leblerüñdür iden } \\
\text { Ḳalemüm āteş-i gam üstüh̆̌ānumı maḳța }\end{array}$ & & müfred/1 & ...-...--/.-.-...- & Başl1k: Ferd \\
\hline $136 \mathrm{a}$ & & $\begin{array}{l}\text { Ḳovsalar da yine gitmem diyü gel eyleme cenk } \\
\text { Ḥażret-i Şeyh-i Şamahì'ye sözüñ ne pūzevenk }\end{array}$ & & matla'/1 & -.--/-.---/-.--/.-- & Başlık: Ferd \\
\hline $136 \mathrm{~b}$ & & 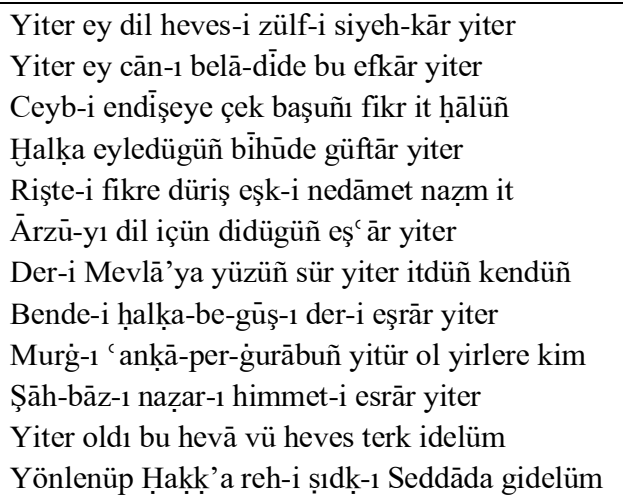 & 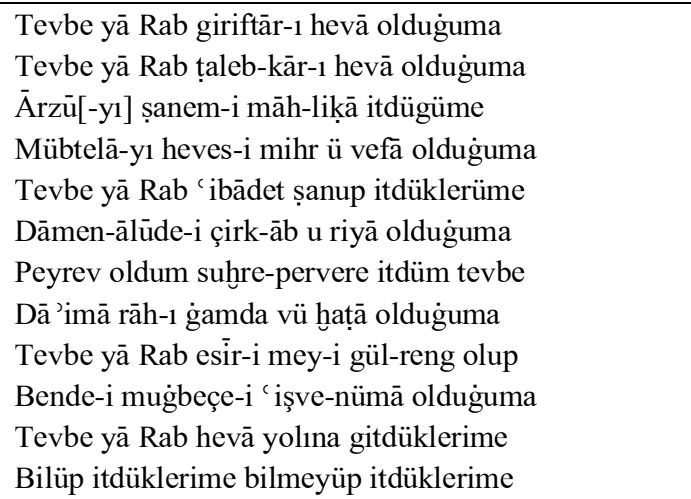 & $\begin{array}{l}\text { terkib-i } \\
\text { bend/8 }\end{array}$ & ..-- /..-- /..-- /... & \\
\hline $138 \mathrm{a}$ & Niyāzī & $\begin{array}{l}\text { Cān bu ilden göçmeden cānānı bulmazsa ne güç } \\
\text { Yārını terk itmedin yārānı bulmazsa ne güç }\end{array}$ & $\begin{array}{l}\text { Bunda gelmekden murād çün kim Ḥaḳk’uñ 'irfānıdur } \\
\text { Ey Niyāzi kişi ol 'irfānı bulmazsa ne güç }\end{array}$ & gazel/7 & -.--/-.---/-.--/-.- & \\
\hline
\end{tabular}

\section{Tablo 6: Mensur Bölümler Tablosu}

\begin{tabular}{|c|c|c|c|c|c|c|}
\hline $\begin{array}{l}\text { Yp. } \\
\text { Nu. }\end{array}$ & Müellif & Eser Adı & Baş & Son & Konu & Açıklamalar \\
\hline $34 \mathrm{a}$ & & & $\begin{array}{l}\text { Hāk-i pāy-1 kīmyāāāsālarına ki nūr-1 hadīka-i dỉde-i devlet ve nūr-1 } \\
\text { ḥadīḳa-i mesned... }\end{array}$ & $\begin{array}{l}\text {...pür-șhḥhat ü cāfiyet ü murabba' } \text {-nişin̄i șadr u devlet ü } \\
\text { 'izzet olmadan hāli olmayalar }\end{array}$ & & \\
\hline $36 \mathrm{a}$ & & & $\begin{array}{l}\text { Muktedā-y1 sultān-1 İslām piş̧vā-y1 maḳām-1 seyyidü'l-enām } \\
\text { sa ādetlü sulțānum... }\end{array}$ & $\begin{array}{l}\text {...niyāz olınur ki melḥūz-1 naẓar-1 'ināyetleri olup } \\
\text { 'indillăhi te ālā müşābih ü me'cūr olalar }\end{array}$ & & $\begin{array}{l}\text { Başlık: İmām Sulțāniye } \\
\text { gönderilmişdür }\end{array}$ \\
\hline $38 \mathrm{~b}$ & & & $\begin{array}{l}\text { 'Unvān şeref-ārān mülūkānı saltanat-1 pỉrān-1 cenāb-1 hażret-i } \\
\text { sultānī dergāh-1 'ālí-i ẓıll-1 şāhī... }\end{array}$ & $\begin{array}{l}\text {...Aḥmed Paşa'nuñ og்lı Muhammed Paşa işbu șūfa } \\
\text { tezkeresi yedine virildi }\end{array}$ & & Başlık: Bā‘ iș-i nemiḳa oldur ki \\
\hline
\end{tabular}




\section{SUMMARY}

In this study, the poetry collection which is registered with number $\mathrm{Yz}$ A 803 in the National Library has been introduced and a table is presented on MESTAP. Collection consists of 138 varak although it is stated that there is 133 varak at the catalog of the library. This is due to the fact that some pages are omitted and the exact number was not given when the collection was subsequently numbered in the library. The collection is blue and red capped, has brown margins and a marbled cardboard. Writing type of collection is talik, paper is watermarked, and the number of lines is various. Shirazi of the collection is bad. The last leaf was written later. We can also say by looking to the writing style that the words at the edge of the page were written afterwards.

In the poetry collection, there are 530 poems which are the works of 134 poets in total. There are 615 poems whose poets can not be identified. In the collection, there are gazels, kasides and musammats. The poet whose poems are included most is Bâkî. After Bâkî, Atâyî and Yahyâ have the most poems in the collection.

There is no exact date for the period which the collection was compiled. We have tried to make an estimate of the date on which the collection was compiled by examining the periods of the poets living, the tezkires and the literary histories. There are poems of poets who lived between the XIV. and XVII. centuries in the collection. That shows us that the collection was compiled at the XVIII century. There are print errors in the collection. For example, there are extra or missing points at the writing of the letters. This situation is most visible in $\dot{\tau}$ and $\tau$. It is also seen that the titles are sometimes given incorrectly. For example, in title 94a there is the phrase "Nazîre-i Münir"; but the poem belongs to Amrî. In 50b there is the phrase "Hâlî" in the title; but there is no mahlas couplet in the poetry. Probably the word "hâlî" at the fourth couplet is thought to be mahlas.

When we look at the arrangement, we see that a certain system is not observed. Poems are not arranged according to poems, redifs or verse forms. However, it is seen that the poems belonging to the same poet are written in succession.

Collection has also included ground poems and nazires. There are 21 ground poems of 18 different poets, 32 nazires written by 25 different poets.

In the collection, the three most used rhythms are the 181 pieces of the fâ'ilâtün fâ'ilâtün fâ'ilâtün fâ'ilün, 135 pieces of the fe'ilâtün fe'ilâtün fe'ilâtün fe'ilün, and 96 pieces of the mefâ‘̂̂lün mefâ‘̂̂lün mefâ‘̂̂lün mefầ̂̂iün. 


\section{KAYNAKÇA}

AK, Coşkun (2001). Bă̆datlı R̂̂hî Dîvanı. Bursa: Uludağ Üniversitesi Yay.

AKGÜL, Ahmet-ÇETIN Kamile (2013). “Millî Kütüphanede Kayıtlı Bulunan Bir Şiir Mecmuası Üzerine". Turkish Studies - International Periodical For The Languages, Literature and History of Turkish or Turkic 8 (1): 99-126.

AKPINAR, Şerife (2015). “Konya Bölge Yazma Eserler Kütüphanesi "3469" Numarada Kayıtlı Bir Şiir Mecmûası". Turkish Studies - International Periodical For The Languages, Literature and History of Turkish or Turkic 10 (8): 341-384.

AKYÜZ, Kenan-BEKEN, Süheyl vd. (1958). Fuẑ̂lî - Türkçe Divan. Ankara: Türkiye İş Bankası Kültür Yay.

ATİLA, Mustafa (2013). “Millî Kütüphanede Bulunan 06 Hk 319/1 Numaralı Gazel Mecmûası Üzerine". Turkish Studies - International Periodical For The Languages, Literature and History of Turkish or Turkic 8 (1): 127-154.

AYKANAT, Timuçin (2013). “Bir Mecmû'a Ekseninde Bazı Tespît ve Değerlendirmeler”. Turkish Studies - International Periodical For The Languages, Literature and History of Turkish or Turkic 8 (1): 155-185.

BAKIRCI, Fatih (2013). “Doğu Türkçesiyle Yazılmış Bir Mecmua I: Şair Hayâî ve Şiirleri”. Turkish Studies - International Periodical For The Languages, Literature and History of Turkish or Turkic 8 (1): 715-743.

CANIM, Rıdvan (2000). Latîfí - Tezkiretü'ş-şu'arâ ve Tabsıratü'n-nuzamâ. Ankara: Atatürk Kültür Merkezi Yay.

ÇAĞLAYAN, Bünyamin-BALABAN, Adem (2013). “Arnavutluk Devlet Kütüphanesindeki (Biblioteka Kombëtare) Türkçe Yazma Mecmualar". Turkish Studies - International Periodical For The Languages, Literature and History of Turkish or Turkic 8 (1): 215-235.

ÇAVUŞOĞLU, Mehmed-TANYERİ, M. Ali (1987). Zatî Divanı (Edisyon Kritik ve Transkripsiyon) Gazeller Kısmı III. Cild. İstanbul: İstanbul Üniversitesi Edebiyat Fakültesi Yay.

DENIZ, Sebahat (t.y.). Tecellî Divanı: Metin Bankası.

ERDOĞAN, Mustafa (2011). Bursalı Rahmî ve Dîvân. http://ekitap.kulturturizm.gov.tr/Eklenti/10600,bursali-rahmi-divanipdf.pdf?0 [02.10.2017].

GENÇER, Salih (2015). “Süleymaniye Kütüphanesi Galata Mevlevihanesi Bölümü 57 Numarada Kayıtlı Şiir Mecmuasına Dair". TÜRÜK Uluslararası Dil, Edebiyat ve Halkbilimi Araştırmaları Dergisi (6): 293-327.

GIYNAŞ, Kamil Ali (2009). Millî Kütüphanedeki Yz. A 803 Numaralı Mecmuanın Transkripsiyonlu Metni. Yüksek Lisans Tezi. Konya: Selçuk Üniversitesi.

GIYNAŞ, Kamil Ali (2011). "Şiir Mecmuaları Hakkında Yapılan Çalışmalar Bibliyografyası". Selçuk Üniversitesi Edebiyat Fakültesi Dergisi (25): 245-260.

GIYNAŞ, Kamil Ali (2014). Pervâne Bey Mecmuası (3 Cilt). İstanbul: Akademik Kitaplar.

GÜRBÜZ, Mehmet (2012). "Şiir Mecmuaları Üzerine Bir Tasnif Denemesi". Eski Türk Edebiyatı Çalışmaları VII, Mecmûa: Osmanlı Edebiyatının Kırkambarı. haz: Hatice AynurMüjgân Çakır-Hanife Koncu-Selim S. Kuru-Ali Emre Özyıldırım. İstanbul: Turkuaz Yayınları. 97-113.

KAFZÂDE FÂ'İZî. Zübdetü'l-eş'âr. Süleymaniye Kütüphanesi. Şehid Ali Paşa Koleksiyonu no. 1877. 
KARADAĞ, Selman (2015). “Millı̂ Kütüphane'de Kayıtlı 06 Mil Yz. A 2860 Numaralı Şiir Mecmuası". Selçuk Üniversitesi Türkiyat Araştırmalarn Dergisi (38): 177-212.

KAVAKLIYAZI, Ahmet (2015). "15. Yüzyıl Şairlerinden Diyarbakırlı Halîlî’nin Şiirleri”. Selçuk Üniversitesi Edebiyat Fakültesi Dergisi (34): 1-88.

KILIÇ, Atabey (2012). "Şiir Mecmualarının Tasnifine Dair". Eski Türk Edebiyatı Çalışmaları VII, Mecmûa: Osmanlı Edebiyatının Kırkambarı. haz. Hatice Aynur-Müjgân Çakır-Hanife Koncu-Selim S. Kuru-Ali Emre Özyıldırım. İstanbul: Turkuaz Yayınları. 75-96.

KILIÇ, Filiz (2010). Âşık Çelebi - Meşấirü̈ş-Şu'arâ, Inceleme-Metin (3 Cilt). İstanbul: İstanbul Araştırmaları Enstitüsü Yay.

KONCU, Hanife-ÇAKIR Müjgân (2012). "Şairleri Yetiştiren Bir Kaynak Olarak Mecmûa". Eski Türk Edebiyatı Çalışmaları VII, Mecmûa: Osmanlı Edebiyatının Kırkambarı. haz. Hatice Aynur-Müjgân Çakır-Hanife Koncu-Selim S. Kuru-Ali Emre Özyıldırım. İstanbul: Turkuaz Yayınları. 117-134.

KÖKSAL, M. Fatih (2012). "Şiir Mecmualarının Önemi ve 'Mecmuaların Sistematik Tasnifi Projesi' (MESTAP)". Eski Türk Edebiyatı Çalışmaları VII, Mecmûa: Osmanlı Edebiyatının Kırkambarı. haz. Hatice Aynur-Müjgân Çakır-Hanife Koncu-Selim S. Kuru-Ali Emre Özyıldırım. İstanbul: Turkuaz Yayınları. 409-431.

KÖKSAL, M. Fatih (2016). Yâ Kebîkeç -Mecmualar Arasında-. İstanbul: Kesit Yay.

KÜÇÜK, Sabahattin (1994). Bâkî Dîvân - Tenkitli Basım. Ankara: Türk Dil Kurumu Yay.

MUTLU, Serpil (2014). "Millî Kütüphane'de Bulunan 06 Hk 578 Numaralı "Mecmû'a-i Müfredât" Üzerine". İK̈̈ V. Uluslararası Türk Dili ve Edebiyatı Öğrenci Kongresi (TUDOK) Bildirileri. 23-24 Haziran 2014. İstanbul: İKÜ Yayınları. 371-384.

ÖZEROL, Nazmi (2013). “Millî Kütüphane'de Kayıtlı 4689/5 Numaralı Şiir Mecmuası”. Turkish Studies - International Periodical For The Languages, Literature and History of Turkish or Turkic 8 (1): 401-410.

ÖZTÜRK, Uğur (2013). “Tezkire Niteliğinde Bir Şiir Mecmuası”. Turkish Studies International Periodical For The Languages, Literature and History of Turkish or Turkic 8 (1): 411-428.

SARAÇ, Mehmet A. Yekta (t.y.). Emrî Dîvânı. http://ekitap.kulturturizm.gov.tr/Eklenti/10607,emridivanipdf.pdf?0 [07.10.2017].

SARIÇIÇEK, Ramazan (2013). “Diyarbakır İhtisas Kütüphanesinde Bir Şiir Mecmûası "Çizgili Defterden Notlar-I-II". Turkish Studies - International Periodical For The Languages, Literature and History of Turkish or Turkic 8 (1): 429-483.

SELÇUK, Bahir-BELLİBAŞ Ahmet (2013). “Millî Kütüphanede Kayıtlı 3692 Numaralı Şiir Mecmuası". Turkish Studies - International Periodical For The Languages, Literature and History of Turkish or Turkic 8 (1): 485-524.

SUNGURHAN EYDURAN, Aysun (2009). Kınalı-zâde Hasan Çelebi - Tezkiretü'ş-Şu'arâ. http://ekitap.kulturturizm.gov.tr/Eklenti/55834,kinalizade-hasan-celebipdf.pdf?0 [02.10.2017].

TANYILDIZ, Ahmet (2012). "Şiir Mecmûalarının Neşri Hakkında". Uluslararası Sosyal Araştırmalar Dergisi 5 (21): 224-239.

TANYILDIZ, Ahmet (2013). “Süleymaniye Kütüphanesi'ndeki 1211 Numaralı Na't ve Mi'râciyye Mecmûası". Turkish Studies - International Periodical For The Languages, Literature and History of Turkish or Turkic 8 (1): 525-547.

TANYILDIZ, Ahmet (2015). “Tahran'da Bulunan Türkçe Bir Şiir Mecmûası ve Neşredilmemiş Bazı Şiirler". Hikmet-Akademik Edebiyat Dergisi 1 (2): 53-101.

SEFAD, 2017 (38): 211-264 
TARLAN, Ali Nihad (1967). Zatî Divanı (Edisyon Kritik ve Transkripsiyon) Gazeller Kısmı I. Cild. İstanbul: İstanbul Üniversitesi Edebiyat Fakültesi Yay.

TULUM, Mertol-TANYERİ, M. Ali (1977). Nev'̂̂ - Divan (Tenkidli Basım). İstanbul: İstanbul Üniversitesi Edebiyat Fakültesi Yay.

TUMAN, Mehmet Nail (2001). Tuhfe-i Nâilî, Divan Şairlerinin Muhtasar Biyografileri. haz. Cemal Kurnaz-Mustafa Tatçı. Ankara: Bizim Büro Basımevi.

TUNÇ, Semra (2000). “Konya Mevlânâ Müzesi Kütüphanesi 2455 Numarada Kayıtlı Bir Şiir Mecmûası". Selçuk Üniversitesi Sosyal Bilimler Enstitüsü Dergisi (6): 105-139.

TUNÇ, Semra (2005). “Topkapı Sarayı Müzesi Kütüphanesi Revan 1985 Numaralı Şiir Mecmûası". Selçuk Üniversitesi Türkiyat Araştırmaları Dergisi (18): 11-87.

TUNÇ, Semra-SEVGİ Ahmet (2015). “Livâyî Bey Mecmû'ası". Selçuk Üniversitesi Edebiyat Fakültesi Dergisi (34): 313-352.

TUNÇ, Semra (2016). “Süleymaniye Kütüphanesi Galata Mevlevihanesi Bölümü 161 Numaralı Şiir Mecmuası". Selçuk Üniversitesi Edebiyat Fakültesi Dergisi (35): 259-294.

UÇAR, Abdullah (2017). "Atatürk Kitaplığ1 Yazma Eserler Bölümü K280 Numaralı Şiir Mecmuası". Selçuk Üniversitesi Edebiyat Fakültesi Dergisi (37): 1-18.

ÜSTÜNER, Kaplan (2014). “Millî Kütüphanede Bulunan 06 Mil Yz A 1793 Numaralı Şiir Mecmuası Üzerine". Celal Bayar Üniversitesi Sosyal Bilimler Dergisi 12 (3): 188-226.

YAZAR, Sadık (2013). “XVI. Yüzyılda Derlenmiş Bir Musammat Mecmûası”. Turkish StudiesInternational Periodical For The Languages, Literature and History of Turkish or Turkic 8 (1): 601-650.

YENITERZİ, Emine (2014). "Dervîş Çelebi, Pîr̂̂-zâde". Türk Edebiyatı İsimler Sözlüğü. http://www.turkedebiyatiisimlersozlugu.com/index.php?sayfa=detay\&detay=1668 [02.10.2017]. 